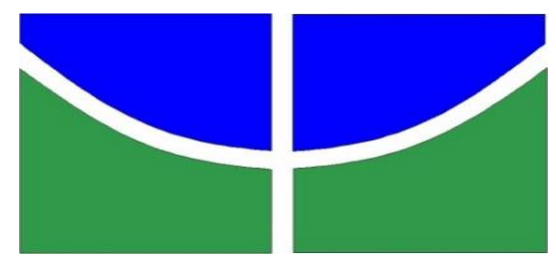

UNIVERSIDADE DE BRASÍLIA

FACULDADE DE EDUCAÇÃO

PROGRAMA DE PÓS-GRADUAÇÃO EM EDUCAÇÃO

CLARA MACHADO DA SILVA ALARCÃO

AS IDEIAS DA MULTIPLICAÇÃO EM DIFERENTES NÍVEIS DO CURRÍCULO NOS ANOS INICIAIS DO ENSINO FUNDAMENTAL:

ENCONTROS E DESENCONTROS 

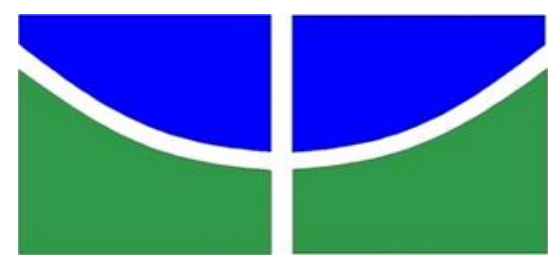

UNIVERSIDADE DE BRASÍLIA

FACULDADE DE EDUCAÇÃO

PROGRAMA DE PÓS-GRADUAÇÃO EM EDUCAÇÃO

CLARA MACHADO DA SILVA ALARCÃO

AS IDEIAS DA MULTIPLICAÇÃO EM DIFERENTES NÍVEIS DO CURRÍCULO NOS ANOS INICIAIS DO ENSINO FUNDAMENTAL:

ENCONTROS E DESENCONTROS

Dissertação apresentada ao

Programa de Pós-Graduação em

Educação da Faculdade de

Educação da Universidade de

Brasília como requisito para a

obtenção do título de Mestre em

Educação.

Orientador: Prof. Dr. Cleyton Hércules Gontijo

Brasília 
Ficha catalográfica elaborada automaticamente, com os dados fornecidos pelo(a) autor(a)

Alarcão, Clara Machado da Silva

AS IDEIAS DA MULTIPLICAÇÃO EM DIFERENTES NÍVEIS

i DO CURRÍCULO NOS ANOS INICIAIS DO ENSINO FUNDAMENTAL: ENCONTROS E DESENCONTROS / Clara Machado da Silva Alarcão; orientador Cleyton Hércules Gontijo. -- Brasília, 2017. $114 \mathrm{p}$.

Dissertação (Mestrado - Mestrado em Educação) -Universidade de Brasília, 2017.

1. Currículo. 2. Multiplicação. 3. Anos Iniciais do Ensino Fundamental. I. Gontijo, Cleyton Hércules, orient. II. Título. 


\section{AS IDEIAS DA MULTIPLICAÇÃO EM DIFERENTES NÍVEIS DO CURRÍCULO NOS ANOS INICIAIS DO ENSINO FUNDAMENTAL: ENCONTROS E DESENCONTROS}

Dissertação apresentada ao
Programa de Pós-Graduação em
Educação da Faculdade de
Educação da Universidade de
Brasília como requisito para a
obtenção do título de Mestre em
Educação.

BANCA EXAMINADORA

Prof. Dr. Cleyton Hércules Gontijo - Presidente Universidade de Brasília

Prof. Dr. Cristiano Alberto Muniz - Membro Interno Universidade de Brasília

Profa. Dra. Erondina Barbosa da Silva - Membro Externo Universidade Católica de Brasília

Profa. Dra. Regina da Silva Pina Neves - Membro Suplente Universidade de Brasília

Brasília, 20 de março de 2017. 


\section{AGRADECIMENTOS}

A Meyre, Jaider e Nádia, meus pais, por me fazerem acreditar que eu posso - e devo - realizar todos os meus sonhos.

À Laís, minha filha, pela inspiração diária.

Ao meu marido, João Paulo, pelo apoio incondicional aos meus projetos.

Aos amigos, pela manutenção do meu bom humor e motivação.

Ao orientador, Prof. Dr. Cleyton Hércules Gontijo, pela confiança no meu projeto, por todas as valiosas contribuições e pela parceria firmada ao longo desses dois anos.

Aos professores do Programa de Pós-Graduação em Educação, pelos momentos de crescimento que me proporcionaram.

Aos professores que compuseram a banca examinadora, Dr. Cristiano Alberto Muniz e Dra. Erondina Barbosa da Silva, por embarcarem com boa vontade neste projeto e por compartilharem comigo sua sabedoria.

Aos colegas da UnB, em especial à Fabiana e à Juliana, pela companhia nessa jornada.

Aos queridos Robson, Shayane, Priscila e Rayza pelo apoio técnico.

À Patrícia, pela primorosa revisão deste texto.

Às professoras que aceitaram participar desta pesquisa, pela disposição e pela qualidade da contribuição.

Ao Inep, pelo incentivo ao longo de todo o curso.

A Deus, pela bênção de ter cada uma dessas pessoas na minha vida. 


\section{RESUMO}

Esta pesquisa teve como objetivo verificar se há compatibilidade na abordagem da multiplicação em diferentes instâncias do currículo do $3^{\circ}$ ano do Ensino Fundamental, tendo como cenário uma escola pública do Distrito Federal. Para isso, utilizaram-se como recursos metodológicos a análise documental, que se deteve sobre o Currículo em Movimento da Educação Básica, os materiais referentes à Avaliação Nacional da Alfabetização (ANA) e o livro didático adotado pela escola participante. Adotaram-se também entrevistas semiestruturadas com duas professoras do ano escolar investigado, as quais foram analisadas por meio da análise de conteúdo. A investigação esteve pautada em dois grandes eixos teóricos: a Teoria dos Campos Conceituais (TCC) de Vergnaud (1982, 1986, 1990, 1994, 2009a, 2009b) e a Abordagem do Currículo por Sacristán (2000). O trabalho, desenvolvido nestes moldes, constatou que o tratamento oferecido à multiplicação, nos níveis do currículo analisado, se dá de forma congruente. É notável também que, apesar das significativas mudanças que os ideais da TCC introduziram nos diversos âmbitos curriculares, algumas práticas e concepções que não condizem com esses ideais parecem perdurar nesses espaços.

Palavras-chave: Currículo; Multiplicação; Anos Iniciais do Ensino Fundamental. 


\begin{abstract}
This research aims to verify the compatibility of multiplication teaching throughout the $3^{\text {rd }}$ grade of Brazilian Elementary School curriculum, scoping a public school in the Federal District. In view of this, documental analysis were used as methodological guideline, which focused on the Currículo em Movimento da Educação Básica ('Curriculum in Movement' for Basic Education), the materials related to the National Literacy Assessment - ANA -, the textbook adopted by the participating school, as well as semi-structured interviews with two teachers of the referred grade, which were analyzed by means of content analysis. The investigation was grounded in two major theoretical axes: the Theory of Conceptual Fields (TCF) proposed by Vergnaud (1982, 1986, 1990, 1994, 2009a, 2009b) and a curriculum approach proposed by Sacristán (2000). The research has then indicated that the approach to multiplication is congruent on the curriculum levels. It is also noteworthy that, despite the significant changes that the ideas of TCF has introduced in the various curricular areas, some practices and conceptions that do not fit with such ideals seems to persist in these contexts.
\end{abstract}

Keywords: Curriculum; Multiplication; First years in Elementary School. 


\section{LISTA DE FIGURAS}

FIGURA 1 - Gráfico da distribuição dos campos da matemática escolar no Projeto Buriti - Alfabetização Matemática - 3ํo ano

FIGURA 2 - Abertura da Unidade 5: Multiplicação 53

FIGURA 3 - Abertura da Unidade 6: Multiplicação e Divisão 59

FIGURA 4 - Classificação da multiplicação e da divisão 93

\section{LISTA DE QUADROS}

QUADRO 1 - Comparativo entre as classificações dos problemas de estrutura multiplicativa 32

QUADRO 2 - Ideias associadas às operações aritméticas na proposta do Currículo em Movimento 46

QUADRO 3 - Objetivos e conteúdos do Currículo em Movimento 48

QUADRO 3 - Objetivos e conteúdos relacionados à multiplicação 49

QUADRO 4 - Situações comuns de multiplicação e divisão 94

QUADRO 5 - Classificação dos problemas nos documentos analisados 98 


\section{LISTA DE SIGLAS}

\begin{tabular}{|c|c|}
\hline ANA & Avaliação Nacional da Alfabetização \\
\hline BIA & Bloco Inicial de Alfabetização \\
\hline BNCC & Base Nacional Comum Curricular \\
\hline BNI & Banco Nacional de Itens \\
\hline BOLEMA & Boletim de Educação Matemática \\
\hline EF & Ensino Fundamental \\
\hline FE & Faculdade de Educação \\
\hline GESTAR & Programa gestão da aprendizagem escolar \\
\hline IDEB & Índice de Desenvolvimento da Educação Básica \\
\hline INEP & $\begin{array}{l}\text { Instituto Nacional de Estudos e Pesquisas Educacionais Anísio } \\
\text { Teixeira }\end{array}$ \\
\hline MEC & Ministério da Educação \\
\hline PCN & Parâmetros Curriculares Nacionais \\
\hline PNAIC & Pacto Nacional pela Alfabetização na Idade Certa \\
\hline PNLD & Programa Nacional do Livro Didático \\
\hline PUC & Pontifícia Universidade Católica \\
\hline SAEB & Sistema de Avaliação da Educação Básica \\
\hline SEEDF & Secretaria de Estado de Educação do Distrito Federal \\
\hline TCC & Teoria dos Campos Conceituais \\
\hline TRI & Teoria de Resposta ao Item \\
\hline UCB & Universidade Católica de Brasília \\
\hline UnB & Universidade de Brasília \\
\hline
\end{tabular}




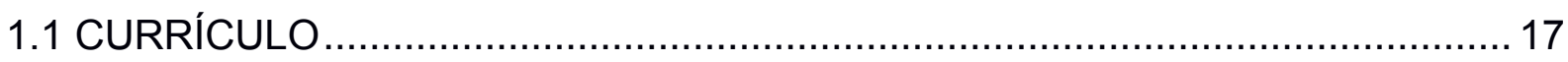

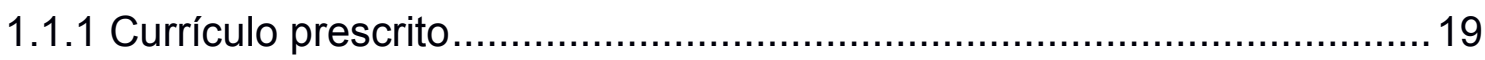

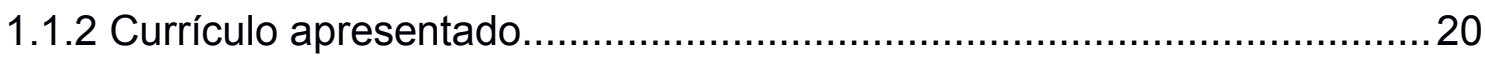

1.1.3 Currículo moldado pelos professores ............................................21

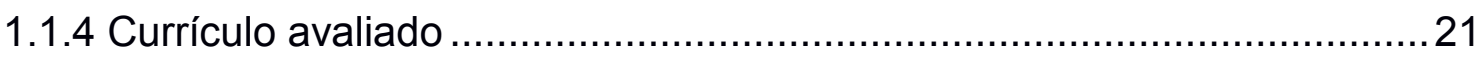

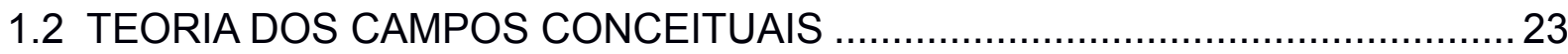

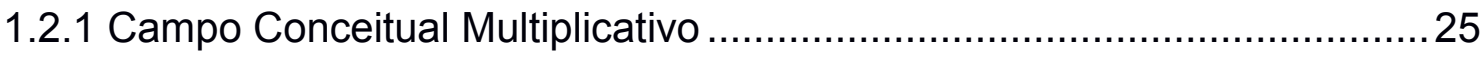

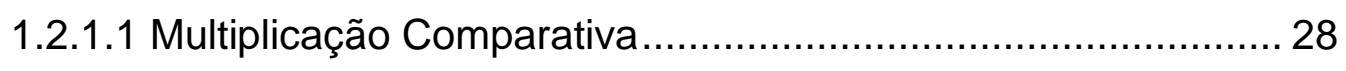

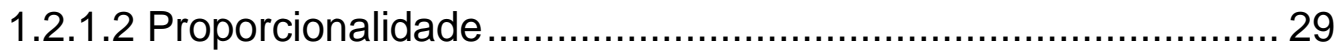

1.2.1.3 Configuração retangular .................................................. 30

1.2.1.4 Combinatória ........................................................................................ 31

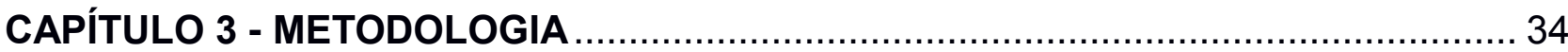

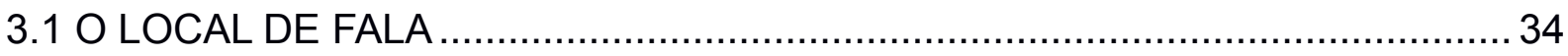

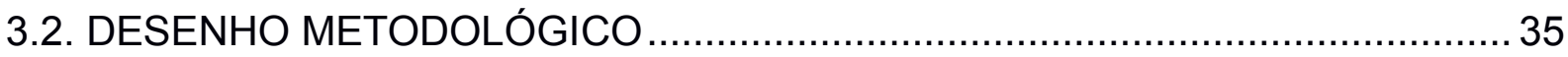

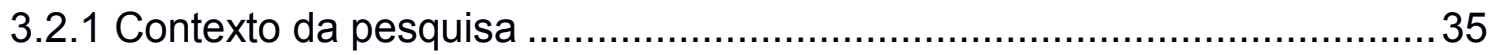

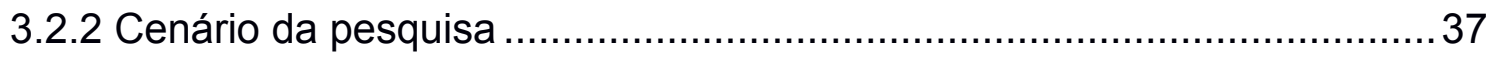

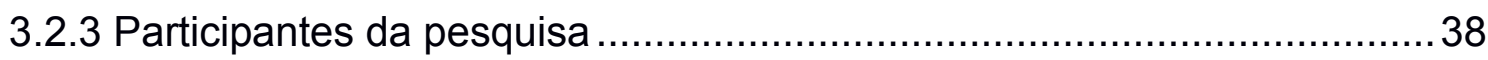

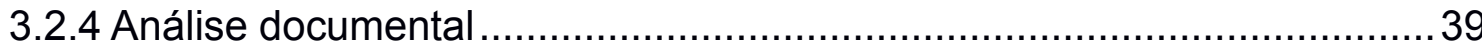


3.2.5 Entrevistas semiestruturadas

3.2.6 Análise de conteúdo

CAPÍTULO 4 - RESULTADOS

4.1 O CURRÍCULO EM MOVIMENTO 44

4.2 O LIVRO DIDÁTICO 50

4.3 A AVALIAÇÃO NACIONAL DA ALFABETIZAÇÃO 61

4.4 O PONTO DE VISTA DAS PROFESSORAS 66

CAPÍTULO 5 - ANÁLISE E DISCUSSÃO DOS RESULTADOS 76

5.1 MULTIPLICAÇÃO COMPARATIVA 76

5.2 PROPORCIONALIDADE 79

5.2.1 Adição de parcelas iguais? 79

5.2.2 Proporcionalidade e reducionismo conceitual 83

5.3 CONFIGURAÇÃO RETANGULAR 85

5.4 COMBINATÓRIA.. 87

5.5 ASPECTOS DIDÁTICOS 90

5.5.1 Sobre categorias e limitações .90

5.5.2 Sobre compreender e operar. .95

CONSIDERAÇÕES FINAIS

REFERÊNCIAS 100 APÊNDICES 105 


\section{HISTORICIDADE DO OBJETO DE PESQUISA}

Sou nascida em Colatina, Espírito Santo, mas - após passar por outros cinco estados - estou em Brasília desde os sete anos de idade. Com mãe, pai e madrasta professores, todos envolvidos com causas sociais, eu estive imersa no contexto educacional desde muito cedo. Além de recortes de papel, livros didáticos, planejamentos e relatórios, debates fervorosos sobre os rumos da educação faziam parte da minha rotina. Seria estranho se dali não tivesse saído uma pedagoga.

Como aluna, tive uma trajetória bastante tranquila. Não poderia contar nos dedos os professores inspiradores que cruzaram meu caminho e que tanto contribuíram para o meu desenvolvimento. Infelizmente, em matemática essa incidência não foi tão grande.

Estudando em escola pública, passei longos períodos sem aulas de matemática e, quando as tive, elas se mostraram pouco esclarecedoras. Sem entender muita coisa, acabei me desmotivando e criando uma verdadeira aversão a essa disciplina.

No ensino médio, a minha dificuldade com a matemática acabou me prejudicando também em física e química, me proporcionando momentos de genuíno desespero. Com o apoio de colegas e um bocado de dedicação extraclasse recheei meu histórico escolar com boas notas que nem sempre refletiram meu aprendizado.

Foi só na Universidade, já cursando Pedagogia, que eu resolvi meu problema com essa área do conhecimento. Aprendendo a ensinar matemática eu percebi que, provavelmente, meus professores também tinham dificuldades e o pouco que aprendi era tudo o que eles tinham a me oferecer. A minha formação inicial, na Universidade de Brasília (UnB), me ofereceu o que a maioria dos pedagogos não encontra nessa etapa e, às vezes, nem nas etapas seguintes de suas formações. Foi nesse espaço que encontrei a minha cota de professores de matemática inspiradores. 
No período em que estagiei em escolas, a prática em sala de aula, desafiadora por natureza, me mostrou que apenas as disciplinas obrigatórias não seriam suficientes para me capacitar para o ensino de matemática. Reconhecendo minhas limitações, procurei dedicar mais tempo à matemática durante a graduação, mas os espaços destinados a essa área se mostraram bastante limitados. Quando o Projeto 4 em Educação Matemática voltou a ser ofertado pelo professor Cristiano Muniz, eu mal podia conter minha empolgação.

Formamos uma equipe pequena, mas comprometida. O Projeto, além da imersão em sala de aula, abrangia momentos de formação com os professores. A experiência mostrou-se riquíssima para todos os envolvidos e me deixou ainda mais interessada pelo ensino da matemática. Dali nasceu meu trabalho de conclusão de curso.

Recém-formada, ingressei no Instituto Nacional de Estudos e Pesquisas Educacionais Anísio Teixeira (Inep) como Pesquisadora-Tecnologista em Informações e Avaliações Educacionais. O exercício profissional nesta autarquia fez emergir inúmeras inquietações que acabaram por semear minha volta à UnB.

Avaliar o ensino ofertado nas escolas brasileiras requer proximidade com os documentos oficiais, livros didáticos, currículos regionais e especialistas - diversas nuances do currículo - para moldar avaliações que se pretendem compatíveis com o que é ensinado nas escolas brasileiras. Mas, existe compatibilidade entre essas diversas fontes? Elas conversam com 0 trabalho desenvolvido pelos professores em sala de aula?

Responder a essas perguntas foi o exercício a que propus para o período do mestrado, limitando minha reflexão à matemática nos anos iniciais e, mais especificamente, ao trabalho com as situações multiplicativas nessa etapa, que parece particularmente frágil. 


\section{INTRODUÇÃO}

Esta pesquisa começou a ser delineada a partir da experiência profissional da pesquisadora. Envolvida com as avaliações em larga escala elaboradas pelo Instituto Nacional de Estudos e Pesquisas Educacionais Anísio Teixeira (Inep), a pesquisadora deparou-se com inúmeros questionamentos a respeito do currículo: os testes externos avaliam o que é, de fato, trabalhado em sala de aula? As habilidades avaliadas são compatíveis com o que os livros didáticos oferecem? As expectativas de aprendizagem expressas pela avaliação em larga escala e livros didáticos são compatíveis com os documentos de prescrição curricular em âmbito nacional, estadual/distrital?

No que diz respeito aos anos iniciais do Ensino Fundamental, área de atuação prioritária da pesquisadora, formada pedagoga, esses questionamentos se fazem especialmente pertinentes no campo da matemática e, particularmente, naquilo que envolve a operação de multiplicação. Isso porque algumas formas de apresentação de situações-problema que envolvem a multiplicação se mostram, nos testes, consideravelmente mais difíceis do que outras.

Para além das inquietações que dizem respeito ao exercício profissional no Inep, a investigação aqui descrita se deu num momento em que se discute a Base Nacional Comum Curricular (BNCC) e poderá vir a contribuir para essa discussão, uma vez que o referido documento se compromete a considerar, em sua elaboração, os documentos curriculares nacionais, estaduais e municipais vigente até então.

Desta forma, a fim de ampliar a compreensão acerca dos elementos envolvidos no processo de ensino e aprendizagem da multiplicação e buscando, assim, esclarecer as dúvidas aqui compartilhadas, parte-se para uma investigação a respeito das relações entre os diversos níveis curriculares no que tange à abordagem das diferentes ideias ${ }^{1}$ da multiplicação. Dois grandes eixos teóricos suportam esse trabalho de pesquisa: a Teoria dos

\footnotetext{
${ }^{1}$ Os documentos analisados para os fins desta pesquisa fazem uso do termo "ideias" para se referir ao que é usualmente definido como "conceitos" pelos pesquisadores que trabalham com a TCC. Aqui, estes termos, serão utilizados de forma equivalente.
} 
Campos Conceituais (TCC) de Vergnaud (1982, 1986, 1990, 1994, 2009a, 2009b) e a Abordagem do Currículo por Sacristán (2000).

A TCC entende que para se construir um conceito é preciso interagir com várias situações e que cada uma dessas situações envolve vários conceitos (VERGNAUD, 1982, 1986, 1990, 1994, 2009a, 2009b). Dessa forma,

Não faz sentido a referência à formação de um conceito isolado, mas sim a um campo composto por diversos conceitos, suas representações e situações que se articulam, formandose o que se denomina de um campo conceitual (GITIRANA et al., 2014, p.10).

A multiplicação e a divisão, em seus diferentes significados, compõem o campo conceitual multiplicativo (VERGNAUD, 1982, 1990, 2009a, 2009b). É importante ressaltar que, embora o foco da pesquisa proposta recaia sobre a multiplicação, esta será compreendida dentro do seu campo conceitual e, portanto, em sua relação intrínseca com a divisão.

A TCC tem servido como referência para importantes documentos orientadores da educação em diversos âmbitos no Brasil: Parâmetros Curriculares Nacionais (PCN), prescrições curriculares regionais, livros didáticos, avaliações em larga escala. A sua representatividade nas produções acadêmicas na área da Educação Matemática também é notável, como exemplo, os programas de mestrado e doutorado na área de educação matemática da Pontifícia Universidade Católica de São Paulo (PUC-SP) têm sido campo fértil para investigações a partir da perspectiva da TCC. Além disso, o trabalho de pesquisadores como Tânia Campos, Sandra Magina, Terezinha Nunes e Cristiano Muniz, entre outros, constituiu uma sólida referência na área.

A referência aos diversos e articulados níveis curriculares está apoiada teoricamente em Sacristán (2000, p.104), que compreende o currículo como "algo construído no cruzamento de influências e campos de atividade diferenciados e inter-relacionados", distinguindo seis fases do desenvolvimento curricular.

O interesse da pesquisa volta-se para a abordagem da multiplicação em quatro desses momentos: (1) currículo prescrito, representado pelo documento 
orientador curricular no Distrito Federal, denominado Currículo em Movimento; (2) currículo apresentado aos professores, representado pelo livro didático; (3) currículo moldado pelos professores, sondado a partir do ponto de vista do próprio professor; e (4) currículo avaliado, expresso por uma avaliação externa.

A pesquisa sobre o currículo de matemática ainda não é um campo consolidado no Brasil, mas esse cenário vem sofrendo modificações. Em 2014, - Boletim de Educação Matemática (BOLEMA) reuniu trabalhos representativos nessa área em uma edição temática organizada por Célia Pires. Iniciativas semelhantes originaram publicações internacionais, como Mathematics Teachers at Work: connecting curriculum materials and classroom instruction (REMILLARD et al., 2009) e Mathematics Curriculum in School Education (LI e LAPPAN, 2014).

O currículo prescrito ainda domina a discussão, mas as relações entre essa esfera e as demais fases de desenvolvimento curricular também vêm sendo exploradas. No geral, esses estudos sugerem que a prática do professor não é definida por prescrições curriculares e que estas, por vezes, estão muito distantes das salas de aula, sendo suplantadas pelo currículo apresentado.

Assim sendo, a pesquisa aqui proposta se guia pelo objetivo geral de verificar se há compatibilidade na abordagem da multiplicação em diferentes instâncias do currículo do $3^{\circ}$ ano do Ensino Fundamental em uma escola pública do Distrito Federal.

Para atender a esse objetivo amplo, foram traçados os seguintes objetivos específicos:

- Analisar as concepções dos professores acerca do ensino e aprendizagem da multiplicação;

- Investigar a abordagem dada às diferentes ideias da multiplicação pelo livro didático adotado pela escola participante;

- Investigar a abordagem dada às diferentes ideias da multiplicação pela Avaliação Nacional da Alfabetização; 
- Investigar a abordagem dada às diferentes ideias da multiplicação pelo Currículo em Movimento. 


\section{CAPÍTULO 1}

\section{PERCURSO TEÓRICO}

Neste capítulo é estabelecido o pano de fundo teórico que sustenta a argumentação travada ao longo da pesquisa. A apresentação dos conceitos e teorias que apoiaram a pesquisadora passa pela exploração do currículo por uma perspectiva crítica, com especial atenção à abordagem delineada por Sacristán (2000) e pela introdução da Teoria do Campos Conceituais de Vergnaud (1982, 1986, 1990, 1994, 2009a, 2009b).

\subsection{Currículo}

O currículo é lugar, espaço, território. O currículo é relação de poder. O currículo é trajetória, viagem, percurso. O currículo é autobiografia, nossa vida, curriculum vitae: no currículo se forja nossa identidade. O currículo é texto, discurso, documento. $O$ currículo é documento de identidade.

Tomaz Tadeu da Silva

O termo currículo é geralmente tido como polissêmico, isto é, com vários significados possíveis (PEDRA, 1997). Pedra (1997), no entanto, adverte que essa polissemia não é indicativa de ambiguidade uma vez que os vários significados atribuídos ao currículo não descrevem realidades diferentes, mas relacionam-se com as diferentes perspectivas lançadas sobre a mesma realidade - são elaborações parciais para uma prática complexa (SACRISTÁN, 2000).

As diversas interpretações do currículo, enquanto produções humanas, "carregam as marcas do tempo e do espaço sociais de suas construções" (PEDRA, 1997, p. 37). Cada uma dessas definições está comprometida, portanto, com um período histórico, uma corrente pedagógica, uma teoria de aprendizagem (MALTA, 2013). São esses fatores que guiam a seleção da qual 
o currículo é resultado: "de um universo mais amplo de conhecimentos e saberes, seleciona-se aquela parte que vai constituir, precisamente, 0 currículo" (SILVA, 2005, p. 15).

Essa seleção é reflexo dos valores dominantes que regem os processos educativos e dos conflitos de interesse travados no meio social (SACRISTÁN, 2000). Por meio dela, procura-se forjar uma identidade tida como ideal. O currículo, desta forma, é um território contestado que envolve questões de saber, identidade e poder (SILVA, 2005). Por reconhecê-lo nesses termos, a pesquisa aqui proposta se alinha com a perspectiva crítica de currículo, que se contrapõe à assepsia científica defendida pelo discurso tradicional (SILVA, 2005).

Para os fins desta investigação, toma-se como referencial teórico o modelo de interpretação do currículo proposto por Sacristán (2000). Este autor entende o currículo como "algo que adquire forma e significado educativo à medida que sofre uma série de processos de transformação dentro das atividades práticas que o tem mais diretamente por objeto" (SACRISTÁN, 2000, p. 9). O fator contextual, nesse sentido, assume grande relevância, evidenciando o significado cultural do currículo:

O currículo modela-se dentro de um sistema escolar concreto, dirige-se a determinados professores e alunos, serve-se de determinados meios, cristaliza, enfim, num contexto, que é o que acaba por lhe dar o significado real (SACRISTÁN, 2000).

Sacristán (2000) distingue seis fases que se inter-relacionam, de forma recíproca e circular, no desenvolvimento curricular. São elas: (1) o currículo prescrito, que atua como referência na ordenação do sistema curricular; (2) o currículo apresentado aos professores, que interpreta o currículo prescrito para aproximá-lo dos docentes; (3) o currículo moldado pelos professores, marcado pelas intervenções dos professores, enquanto agentes ativos, na configuração dos significados das propostas curriculares; (4) o currículo em ação, entendido como a concretização do currículo em sala de aula à qual são inerentes as influências dos esquemas teóricos e práticos do professor; (5) o currículo 
realizado, que engloba os complexos efeitos da prática; e (6) o currículo avaliado, que impõe critérios para o ensino e aprendizagem.

A pesquisa aqui descrita se concentra na abordagem das situações multiplicativas em quatro desses momentos, relacionando-os com alguns dos materiais curriculares direcionados ao primeiro ciclo dos anos iniciais do Ensino Fundamental no Distrito Federal: (1) currículo prescrito, representado pelo documento orientador curricular no Distrito Federal; (2) currículo apresentado aos professores, representado pelo livro didático; (3) currículo moldado pelos professores, que será sondado a partir do ponto de vista do próprio professor (4) currículo avaliado, expresso por uma avaliação externa.

\subsubsection{Currículo prescrito}

É necessário considerar que o currículo possui papel fundamental na ordenação do sistema educativo e, portanto, é alvo de regulações econômicas, políticas e administrativas (SACRISTÁN, 2000). Sacristán (2000) afirma que "ordenar a distribuição do conhecimento através do sistema educativo é um modo não só de influir na cultura, mas também em toda a ordenação social e econômica da sociedade" (p.108). Tal ordenação se dá pela política curricular, instrumentalizada por meio do currículo prescrito.

Essa dimensão curricular traça, a partir de decisões políticas e administrativas, o que se espera das aprendizagens dos alunos, indicando diretrizes, objetivos e processos de ensino e aprendizagem (VECE e CURI, 2014, p.624). Tais características conferem ao currículo prescrito a propriedade de ponto de partida para a elaboração de materiais e controle do sistema, entre outros (SACRISTÁN, 2000).

No Brasil, são vários os documentos que cumprem essa função na Educação Básica. Além de iniciativas nacionais como os Parâmetros Curriculares Nacionais (BRASIL, 1997), Direitos de Aprendizagem (BRASIL, 2012a) e a Base Nacional Comum Curricular (BRASIL, 2016a) - que está agora em sua segunda versão e ainda em discussão -, existem também os 
desdobramentos regionais, que complementam e adequam essas propostas aos níveis estaduais e municipais.

No âmbito desta pesquisa, o currículo prescrito foi representado por um desses desdobramentos: o Currículo em Movimento da Educação Básica (GDF, 2013a, 2013b), orientação curricular vigente no Distrito Federal. Esse documento engloba, para os anos iniciais do Ensino Fundamental, prescrições para as áreas de Linguagens, Matemática, Ciências Humanas, Ciências da Natureza e Ensino Religioso, propondo que estas sejam trabalhadas de forma interdisciplinar e articuladas com eixos transversais e integradores.

\subsubsection{Currículo apresentado}

O currículo apresentado é constituído por materiais que "operacionalizam as orientações curriculares expressas nos currículos prescritos" (VECE e CURI, 2014, p. 624). Sacristán (2000) pondera que, dadas as condições não ideais de trabalho e formação dos professores e a complexidade dos saberes profissionais e prática docentes, as prescrições curriculares são pouco operativas e os professores são levados a recorrer a pré-elaborações do currículo.

É importante considerar, no entanto, que esse não é um cenário fixo. Sacristán (2000) chama a atenção para o fato de que tais circunstâncias são "mutantes e melhoráveis" (p.149) e, portanto,

A necessidade de elaborações intermediárias do currículo para os professores, sendo uma necessidade conjuntural, não pode nem deveria se converter numa prática de controle e desprofissionalização dos mesmos, mas ser um meio entre outros possíveis e necessários (SACRISTÁN, 2000, p.151).

Em consonância com o exposto, Pires e Curi (2013) constatam que "documentos curriculares prescritos parecem ter pouco impacto nas práticas docentes, que são influenciadas por outros materiais curriculares" e afirmam que "entre nós, os materiais mais difundidos e utilizados são, sem dúvida, os livros didáticos" (p.58). 
Nacionalmente, a distribuição de livros para os estudantes da educação básica das escolas públicas se dá por meio do Programa Nacional do Livro Didático (PNLD). As escolas podem escolher, dentre as obras que atendem os critérios estabelecidos pelo programa, os livros que melhor se adequam ao seu projeto político-pedagógico (BRASIL, 2012b).

\subsubsection{Currículo moldado pelos professores}

Sacristán (2000) considera que "o currículo molda os docentes, mas é traduzido na prática por eles mesmos - a influência é recíproca". Isso porque o professor não é objeto, e sim sujeito ativo na concretização dos currículos.

Os professores moldam, a partir de sua cultura profissional, as propostas que chegam a eles - o currículo prescrito e o currículo apresentado procurando ajustá-las e articulá-las "aos planos de curso das diferentes disciplinas, de modo a convergir para as metas mais amplas da escola, com base no diagnóstico da comunidade onde se insere" (VECE e CURI, 2014, p.624). Essa compreensão implica reconhecer a escola como espaço de reconstrução do conhecimento e do currículo ditado por forças externas.

Para os fins desta pesquisa, a apreensão da ação modeladora do professor sobre o currículo foi buscada por meio de entrevistas com esses sujeitos e apresentada, portanto, a partir do ponto de vista deles.

\subsubsection{Currículo avaliado}

A avaliação subsidia a reorientação do trabalho pedagógico para melhor atender às necessidades dos aprendizes. Avaliar pode ser entendido como "um conjunto de procedimentos e de processos de coleta, de tratamento e de comunicação de informações, realizado com o objetivo de tomada de decisões" (BRASIL, 2016b, p. 5). A avaliação, no entanto, está fortemente ligada à emissão de juízos de valor, uma vez que as informações recolhidas devem ser capazes de "revelar algo de confiável e substancial sobre o valor de um objeto, de um processo ou de um comportamento" (BRASIL, 2016b, p. 5). 
Em busca de resultados positivos, os aspectos valorizados pela avaliação tendem a ser, também, os mais valorizados no ensino e esta "acaba impondo critérios para o ensino do professor e para a aprendizagem do aluno" (SACRISTÁN, 2000, p. 106), exercendo pressão modeladora sobre o currículo.

Os aspectos curriculares ressaltados pela avaliação são "talvez coerentes, talvez incongruentes com os propósitos manifestos de quem prescreveu o currículo, de quem o elaborou, ou com os objetivos do próprio professor" (SACRISTÁN, 2000, p. 106), assumindo características próprias. Essa instância concretiza-se por meio de procedimentos formais ou informais, externos ou realizados pelo professor (SACRISTÁN, 2000). No âmbito desta pesquisa foi considerada a avaliação em sua dimensão externa.

O $3^{\circ}$ ano, etapa final do primeiro ciclo dos anos iniciais do Ensino Fundamental, é alvo da Avaliação Nacional da Alfabetização (ANA). A ANA compõe o Pacto Nacional pela Alfabetização na Idade Certa - PNAIC, compromisso firmado entre os governos federal, estaduais, municipais e do Distrito Federal para garantir a alfabetização das crianças até os 8 anos de idade, ao final do 3o ano do Ensino Fundamental (BRASIL, 2013a).

Essa avaliação é nacional, censitária e tem por objetivo "fazer um diagnóstico amplo do processo de alfabetização nas escolas públicas brasileiras" (BRASIL, 2013b, p. 7). Para isso, a avaliação utiliza como instrumentos testes de desempenho nas áreas de Língua Portuguesa e Matemática, além de questionários contextuais (BRASIL, 2013b).

A abordagem das situações multiplicativas pela ANA foi investigada a partir de materiais como o documento básico, a matriz de referência para os testes de matemática e os itens já utilizados em suas duas edições (2013 e 2014) ou aptos para utilização (com a devida autorização do Inep, autarquia responsável pela gestão do Banco Nacional de Itens - BNI).

Traçada a delimitação teórica do currículo para os fins desta pesquisa, parte-se agora para as contribuições fornecidas pela TCC para as reflexões necessárias a esse trabalho investigativo. 


\subsection{Teoria dos Campos Conceituais}

A multiplicação, delimitação temática da análise do currículo aqui proposta, foi compreendida a partir da Teoria dos Campos Conceituais. Elaborada pelo psicólogo francês Gérard Vergnaud, a TCC serve, dentre outras possibilidades, ao objetivo de explicar a construção e desenvolvimento de conceitos matemáticos por crianças e adolescentes (GITIRANA et al., 2014).

A TCC, enquanto teoria cognitivista, admite que o conhecimento se constitui na interação adaptativa do indivíduo com o meio (FRANCHI, 1999). Nessa perspectiva, a criança assume papel ativo no processo educativo e ao professor cabe estimular e utilizar a atividade infantil, relacionando os conteúdos ensinados à atividade possível da criança (VERGNAUD, 2009a). Essa complexa tarefa demanda conhecimentos aprofundados não só a respeito da criança e do desenvolvimento infantil, mas também dos conteúdos em si, pois, só desta forma, o docente poderá compreender as dificuldades e etapas experienciadas por seus alunos no processo de aprendizagem (VERGNAUD, 2009a).

Para a TCC, um conceito é definido a partir três elementos: situação, invariantes operacionais e representação - a terna de conjuntos (S, I, R) (VERGNAUD, 1982, 1986, 1990, 1994, 2009b). É importante ter em mente que a integração entre esses elementos não acontece espontaneamente, demandando esforços por parte do professor e dos alunos (GITIRANA et al., 2014).

A situação (S) é o que torna o conceito significativo e, portanto, é de fundamental importância na construção conceitual. Isso porque, se cada situação envolve vários conceitos, é também verdadeiro que os procedimentos mobilizados dependem necessariamente da situação, do contexto (MUNIZ, 2009).

Os invariantes operacionais (I) - que podem se manifestar de maneira explícita ou implícita - consistem nos conceitos e teoremas em ato utilizados para analisar e dominar a situação que se apresenta (GITIRANA et al, 2014; FRANCHI, 1999). Enquanto os conceitos-em-ato se referem às propriedades e 
relações evocadas pelo aluno diante de determinada situação, os teoremasem-ato dizem respeito às proposições de ação sobre ela (FRANCHI, 1999). Gitirana et al. (2014) apontam que o reconhecimento e análise desses elementos auxiliam o professor a elaborar situações-problema que ajudem os alunos a avançar no processo de aprendizagem, promovendo a passagem do conhecimento intuitivo para o conhecimento explícito.

O último elemento da terna, $(R)$, refere-se à representação simbólica desses invariantes, das situações e procedimentos mobilizados (GITIRANA et al., 2014). A importância dessas representações reside no fato de que, para além da função comunicativa, elas atuam sobre a organização das experiências e dos pensamentos, constituindo um instrumento de conceitualização do real (FRANCHI, 1999).

Nesse cenário, a multiplicação, assim como demais operações matemáticas, deve ser entendida em sua multiplicidade conceitual. Isso porque as diversas situações que demandam uma multiplicação invocam invariantes operatórios diferentes que serão representados também de maneira diferente, configurando, portanto, uma variedade de conceitos.

É fato que essa diversidade é por vezes desconsiderada ou até mesmo ignorada por parte dos professores, e a escola acaba por restringir cada operação a apenas uma dimensão conceitual. Muniz (2009) define esse fenômeno como reducionismo conceitual e alerta que essa postura restringe a instrumentalização dos alunos para dominar as situações que implicam os demais conceitos das operações matemáticas.

A TCC entende que

Um conceito torna-se significativo por meio de uma variedade de situações, e diferentes aspectos dos mesmos conceitos e operações estão envolvidos em diferentes situações. Ao mesmo tempo, uma situação não pode ser analisada com a ajuda de apenas um conceito, ao menos vários conceitos são necessários (VERGNAUD, 1994, p.44, tradução nossa).

Considerando esse pressuposto, não faz sentido referir-se à formação de um conceito isolado, mas sim a campos conceituais, definidos por Vergnaud (1982) como "um conjunto de situações cujo domínio requer uma variedade de 
conceitos, procedimentos e representações simbólicas estreitamente conectadas umas com as outras".

Desta forma, enquanto a adição e a subtração fazem parte de um mesmo campo conceitual, denominado aditivo, multiplicação e divisão compõem o campo conceitual multiplicativo. É importante compreender que, embora exista continuidade estrutural entre um campo e outro, há uma importante descontinuidade de significado (GITIRANA et al., 2014). A investigação aqui descrita se dedicou ao campo conceitual multiplicativo, que contextualizou a abordagem da multiplicação.

\subsubsection{Campo Conceitual Multiplicativo}

O Campo Conceitual Multiplicativo pode ser definido, para os fins desta pesquisa, como um conjunto de situações que demandam uma multiplicação, uma divisão ou a combinação entre elas para serem dominadas (VERGNAUD, 1982, 1990, 1994, 2009a).

Essas situações implicam um raciocínio diferente daquele presente no Campo Conceitual Aditivo: enquanto o raciocínio aditivo envolve relações entre as partes e o todo, o raciocínio multiplicativo recai sobre relações fixas entre variáveis (NUNES e BRYANT, 1997). Ademais, o Campo Conceitual Multiplicativo explora relações entre grandezas iguais ou diferentes (GITIRANA et al., 2014), o que, da mesma forma, representa uma descontinuidade significativa em relação às estruturas aditivas. Sobre as rupturas entre um campo e outro, podemos listar ainda a inclusão das relações quaternárias pelas situações multiplicativas: enquanto o Campo Aditivo lida com relações entre três elementos (ternárias), no Campo Multiplicativo existem também relações quaternárias, como no problema "Marta vai comprar 3 pacotes de chocolate. Cada pacote custa $R \$ 8,00$. Quanto ela vai pagar pelos 3 pacotes?" (BRASIL, 1997, p.110), que coloca em jogo quatro quantidades, duas a duas de mesmo tipo.

Apesar dessas considerações, nas escolas ainda perdura a crença de que não há transformação do raciocínio aditivo para o multiplicativo (NUNES e 
BRYANT, 1997). A partir desse ponto de vista, ignora-se que as estruturas multiplicativas apresentam à criança um "conjunto inteiramente novo de sentidos de número e um novo conjunto de invariáveis, todas as quais estão relacionadas à multiplicação e à divisão, mas não à adição e subtração" (NUNES e BRYANT, 1997, p.142).

As noções presentes nas estruturas multiplicativas são, de fato, mais complexas do que aquelas encontradas nas estruturas aditivas (NUNES e BRYANT, 1997), mas já são compreendidas em sua forma mais elementar por crianças tão novas quanto as de seis anos (SANTOS et al., 2013; NUNES et al., 2009; NUNES e BRYANT, 1997). A estratégia largamente difundida de introduzir a multiplicação e a divisão, respectivamente, como adição e subtração de parcelas repetidas torna-se questionável nesse contexto (GITIRANA et al., 2014; MUNIZ, 2009; NUNES et al., 2009; NUNES e BRYANT, 1997; VERGNAUD, 2009a).

Nunes et al. (2009) sugerem que é mais eficaz introduzir a multiplicação e a divisão a partir de esquemas de ação próprios, explorando a compreensão precoce das relações multiplicativas. Essa estratégia de ensino é coerente com o que postula Vergnaud (2009a), que entende que a complexidade das noções inerentes ao Campo Conceitual Multiplicativo não exime o professor de trabalhá-las, sempre com prudência e com significado para as crianças.

A abordagem das estruturas multiplicativas deve ainda considerar a multiplicidade conceitual que esse campo abrange, o que, como exposto anteriormente, frequentemente não acontece. Muniz (2009) alerta que muitos professores sequer têm ciência dessa diversidade conceitual, uma vez que não encontram orientações a esse respeito nos cursos de formação. Tal condição alimenta a persistência da crença de que o domínio da tabuada e de alguns procedimentos de cálculo é suficiente para obter sucesso na resolução de situações multiplicativas (SANTOS et al., 2013), ideia vinculada ao reducionismo conceitual (MUNIZ, 2009, p. 102).

Essa compreensão limitada dos conceitos da multiplicação e da divisão compromete o domínio do raciocínio multiplicativo pelos alunos. Isso porque vários dos procedimentos empregados para a resolução das mais diversas 
situações multiplicativas não são imediatamente redutíveis a um procedimento canônico de divisão ou multiplicação, uma vez que estes não correspondem diretamente aos processos cognitivos empregados pelos alunos (FRANCHI, 1999).

A multiplicação e a divisão, portanto, não podem ser reduzidas a cálculos e a algoritmos formais, devendo ser entendidas como "formas de organização do pensamento a partir das estruturas e conceitos matemáticos específicos de um determinado raciocínio" (GUERIOS et al., 2014). A competência para resolver problemas multiplicativos, desta forma, vai muito além da habilidade com a tabuada e procedimentos de cálculo. Ela demanda, para seu desenvolvimento pleno, um longo período de tempo vivenciando uma grande variedade de problemas que explorem as diferentes facetas das operações que compõem o Campo Conceitual Multiplicativo (GITIRANA et al., 2014).

Essa variedade de situações pelas quais o raciocínio multiplicativo se manifesta foi classificada de diferentes formas pelos pesquisadores que se dedicam a essa área. Vergnaud (2009a) ateve-se a distinguir as principais classes de problemas multiplicativos, admitindo que várias classificações podem ser traçadas a partir de diversos critérios: o caráter discreto ou contínuo das quantidades em jogo, a forma da relação multiplicativa, as propriedades dos números utilizados, entre outros. É natural, portanto, que esse exercício não tenha chegado a resultados unânimes.

As diferentes possibilidades de classificação têm o mérito de propor o desvelamento de classes e subclasses de problemas que colocam em evidência dificuldades distintas e merecem atenção específica. Essas classificações são um recurso para alimentar o conhecimento matemático e pedagógico do professor, que, entendendo as estruturas dos problemas, pode ofertar aos seus alunos uma variedade que atenda às necessidades da classe (MUNIZ, 2009). Isso não significa que o professor deva tomar a classificação dos problemas como conteúdo a ser ensinado ou mesmo que deva trabalhá-los separadamente (GUERIOS et al., 2014). 
No âmbito desta pesquisa, foi adotada a classificação das situações multiplicativas traçada pelos PCN (BRASIL, 1997) com base na TCC, sem excluir, no entanto, a contribuição de outros autores para o enriquecimento da caracterização das categorias. Considera-se que os PCN, enquanto prescrição curricular nacional, não só se encontram bem difundidos entre os professores como também são referência para a elaboração dos documentos de prescrições curriculares regionais e para a organização dos livros didáticos. Tal característica é de grande valor para os objetivos da pesquisa.

Os PCN (BRASIL, 1997) distinguem quatro grupos de situações que se relacionam com a multiplicação e a divisão. Esses grupos serão aqui expostos em paralelo àqueles definidos por Vergnaud (2009a), buscando-se explicitar a correspondência entre uma classificação e outra.

\subsubsection{Multiplicação Comparativa}

Essas situações são apresentadas por Vergnaud (2009a) como casos de um único espaço de medidas. Nesses problemas, duas grandezas de mesmo tipo são comparadas por meio de uma razão, configurando uma relação ternária (GITIRANA et al., 2014). As expressões " $x$ vezes mais" e " $x$ vezes menos" são características dessa forma de relação (VERGNAUD, 2009a), assim como os numerais multiplicativos (dobro, triplo etc.).

Os PCN (BRASIL, 1997, p.109) apresentam, dentro desse grupo, situações de multiplicação:

Marta tem 4 selos e João tem 5 vezes mais selos que ela. Quantos selos tem João?

E de divisão:

Lia tem $R \$ 10,00$. Sabendo que ela tem o dobro da quantia de Pedro, quanto Pedro tem?

Vergnaud (2009a) ainda distingue uma terceira situação, também de divisão, em que, ao invés de buscar-se uma medida - quantos selos João tem, 
quanto dinheiro Pedro tem - busca-se um escalar, isto é, o número de replicações necessárias. Um exemplo dessa classe de problemas seria:

São necessários 2 metros de tecido para fazer uma saia e 6 metros para um conjunto. Um conjunto utiliza quantas vezes mais tecido do que uma saia? (VERGNAUD, 2009a, p. 262, adaptado).

\subsubsection{Proporcionalidade}

Esse grupo de situações está associado à comparação entre razões. Por estarem muito presentes em situações cotidianas, os problemas deste tipo são geralmente compreendidos com mais facilidade pelos alunos (BRASIL, 1997). Buscando um paralelo com a classificação elaborada por Vergnaud (2009a), as situações de proporcionalidade são correspondentes ao isomorfismo de medidas. Essa categoria coloca em jogo quatro quantidades (relação quaternária) sendo que duas quantidades são medidas de certo tipo e as duas outras medidas de outro tipo (VERGNAUD, 2009a). Nos problemas mais simples, umas das quantidades envolvidas é igual a 1 (VERGNAUD, 2009a). De acordo com a posição da incógnita, são possíveis as seguintes situações:

1. Situações de multiplicação:

Marta vai comprar três pacotes de chocolate. Cada pacote custa $R \$$ 8,00. Quanto ela vai pagar pelos três pacotes? (BRASIL, 1997, p. 110).

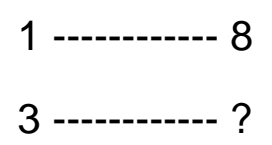

2. Situações de divisão com a ideia de repartir igualmente - também classificadas como busca do valor unitário por Vergnaud (2009a):

Marta pagou $R \$ 24,00$ por 3 pacotes de chocolate. Quanto custou cada pacote? (BRASIL, 1997, p. 110).

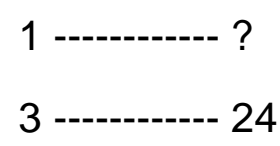


3. Situações de divisão com a ideia de determinar quanto cabe, denominada busca da quantidade de unidades por Vergnaud (2009a):

Marta gastou $R \$ 24,00$ na compra de pacotes de chocolate que custavam $R \$ 3,00$ cada um. Quantos pacotes de chocolate ela comprou? (BRASIL, 1997, p. 110).

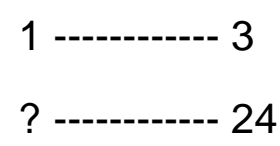

\subsubsection{Configuração retangular}

Nesta categoria estão contidos os problemas que exploram a leitura de linha por coluna ou vice-versa (GUERIOS et al., 2014) e que se relacionam, então, com o conceito de área (MUNIZ, 2009; GITIRANA et al., 2014). Vergnaud (2009a) situa a ideia de configuração retangular na classe de produto de medidas. Essas situações envolvem três quantidades, das quais uma é o produto das duas outras (VERGNAUD, 2009a), estabelecendo, portanto, uma relação ternária. Seguindo a mesma linha, autores como Muniz (2009) e Gitirana et al. (2014) associam a configuração retangular à ideia de combinação/produto cartesiano. Nos PCN, no entanto, optou-se por apresentar configuração retangular e combinatória separadamente.

A partir da ideia de configuração retangular são possíveis problemas que demandam uma multiplicação, como no exemplo a seguir:

Num pequeno auditório, as cadeiras estão dispostas em 7 fileiras e 8 colunas. Quantas cadeiras há no auditório? (BRASIL, 1997, p. 110).

Ou uma divisão, conforme a situação abaixo:

As 56 cadeiras de um auditório estão dispostas em fileiras e colunas. Se são 7 as fileiras, quantas são as colunas? (BRASIL, 1997, p. 111). 


\subsubsection{Combinatória}

Esse grupo abrange situações associadas à ideia de análise combinatória, evidenciando o conceito de produto cartesiano (BRASIL, 1997). Os problemas desse tipo envolvem a necessidade de verificar as possibilidades de combinação entre elementos de diferentes conjuntos (GUERIOS et al., 2014). Na classificação de Vergnaud (2009a), a ideia de combinação, assim como a de configuração retangular, está contida na classe de produto de medidas.

Aqui é possível identificar situações de multiplicação nas quais, conhecendo-se as medidas elementares, busca-se a medida-produto (VERGNAUD, 2009a), como no exemplo:

Tendo duas saias - uma preta e uma branca - e três blusas - uma rosa, uma azul e uma cinza -, de quantas maneiras diferentes posso me vestir? (BRASIL, 1997, p. 111, adaptado).

E de divisão, em que se busca uma das medidas elementares conhecendo-se a outra e a medida produto (VERGNAUD, 2009a):

Numa festa, foi possível formar 12 casais diferentes para dançar. Se havia 3 moças e todos os presentes dançaram, quantos eram os rapazes? (BRASIL, 1997, p. 112).

A correspondência entre a classificação das situações multiplicativas exposta nos PCN (BRASIL, 1997) e aquela inicialmente elaborada por Vergnaud (2009a) é apresentada de forma resumida no Quadro 1, com destaque (em cinza) para as ideias da multiplicação: 
QUADRO 1 - Comparativo entre as classificações dos problemas de estrutura multiplicativa

\begin{tabular}{|c|c|c|}
\hline \multirow{2}{*}{ EXEMPLOS DE PROBLEMAS } & \multicolumn{2}{|c|}{ CLASSIFICAÇÃO DOS PROBLEMAS } \\
\hline & VERGNAUD & PCN \\
\hline $\begin{array}{l}\text { Marta tem } 4 \text { selos e João tem } 5 \\
\text { vezes mais selos que ela. Quantos } \\
\text { selos tem João? (BRASIL, 1997, } \\
\text { p.109) }\end{array}$ & $\begin{array}{l}\text { Caso de um único } \\
\text { espaço de medidas } \\
\text { (multiplicação) }\end{array}$ & $\begin{array}{l}\text { Multiplicação comparativa } \\
\text { (multiplicação) }\end{array}$ \\
\hline $\begin{array}{l}\text { Lia tem } \mathrm{R} \$ 10,00 \text {. Sabendo que ela } \\
\text { tem o dobro da quantia de Pedro, } \\
\text { quanto Pedro tem? (BRASIL, 1997, } \\
\text { p.109, adaptado) }\end{array}$ & $\begin{array}{l}\text { Caso de um único } \\
\text { espaço de medidas } \\
\text { (busca de uma } \\
\text { medida) }\end{array}$ & $\begin{array}{l}\text { Multiplicação comparativa } \\
\text { (divisão) }\end{array}$ \\
\hline $\begin{array}{l}\text { São necessários } 2 \text { metros de tecido } \\
\text { para fazer uma saia e } 6 \text { metros } \\
\text { para um conjunto. Um conjunto } \\
\text { utiliza quantas vezes mais tecido } \\
\text { do que uma saia? (VERGNAUD, } \\
\text { 2009a, p.263, adaptado) }\end{array}$ & $\begin{array}{l}\text { Caso de um único } \\
\text { espaço de medidas } \\
\text { (busca do fator } \\
\text { escalar) }\end{array}$ & - \\
\hline $\begin{array}{l}\text { Marta vai comprar três pacotes de } \\
\text { chocolate. Cada pacote custa } R \$ \\
8,00 \text {. Quanto ela vai pagar pelos } \\
\text { três pacotes? (BRASIL, 1997, } \\
\text { p.110) }\end{array}$ & $\begin{array}{l}\text { Isomorfismo de } \\
\text { medidas } \\
\text { (multiplicação) }\end{array}$ & $\begin{array}{l}\text { Proporcionalidade } \\
\text { (multiplicação) }\end{array}$ \\
\hline $\begin{array}{l}\text { Marta pagou } \mathrm{R} \$ 24,00 \text { por } 3 \\
\text { pacotes de chocolate. Quanto } \\
\text { custou cada pacote? (BRASIL, } \\
\text { 1997, p.110) }\end{array}$ & $\begin{array}{l}\text { Isomorfismo de } \\
\text { medidas (busca do } \\
\text { valor unitário) }\end{array}$ & $\begin{array}{c}\text { Proporcionalidade (repartir } \\
\text { igualmente) }\end{array}$ \\
\hline $\begin{array}{l}\text { Marta gastou } R \$ 24,00 \text { na compra } \\
\text { de pacotes de chocolate que } \\
\text { custavam } R \$ 3,00 \text { cada um. } \\
\text { Quantos pacotes de chocolate ela } \\
\text { comprou? (BRASIL, 1997, p.110) }\end{array}$ & $\begin{array}{l}\text { Isomorfismo de } \\
\text { medidas (busca da } \\
\text { quantidade de } \\
\text { unidades) }\end{array}$ & $\begin{array}{c}\text { Proporcionalidade } \\
\text { (determinar quanto cabe) }\end{array}$ \\
\hline $\begin{array}{l}\text { Num auditório, as cadeiras estão } \\
\text { dispostas em } 7 \text { fileiras e } 8 \text { colunas. } \\
\text { Quantas cadeiras há no auditório? } \\
\text { (BRASIL, 1997, p.110, adaptado) }\end{array}$ & \multirow{2}{*}{$\begin{array}{l}\text { Produto de medidas } \\
\text { (multiplicação) }\end{array}$} & $\begin{array}{l}\text { Configuração retangular } \\
\text { (multiplicação) }\end{array}$ \\
\hline $\begin{array}{l}\text { Tendo duas saias e três blusas, de } \\
\text { quantas maneiras diferentes posso } \\
\text { me vestir? (BRASIL, 1997, p.111, } \\
\text { adaptado) }\end{array}$ & & Combinatória (multiplicação) \\
\hline $\begin{array}{l}\text { As } 56 \text { cadeiras de um auditório } \\
\text { estão dispostas em fileiras e } \\
\text { colunas. Se são } 7 \text { as fileiras, } \\
\text { quantas são as colunas? (BRASIL, } \\
\text { 1997, p.111) }\end{array}$ & \multirow{2}{*}{$\begin{array}{l}\text { Produto de medidas } \\
\text { (divisão) }\end{array}$} & $\begin{array}{c}\text { Configuração retangular } \\
\text { (divisão) }\end{array}$ \\
\hline $\begin{array}{l}\text { Numa festa, foi possível formar } 12 \\
\text { casais diferentes para dançar. Se } \\
\text { havia } 3 \text { moças e todos os } \\
\text { presentes dançaram, quantos eram } \\
\text { os rapazes? (BRASIL, 1997, p.112) }\end{array}$ & & Combinatória (divisão) \\
\hline
\end{tabular}

Fonte: Elaboração própria 
É importante considerar que esses esquemas multiplicativos não são inicialmente compreendidos como coordenados entre si (NUNES et al., 2009). Como esta é uma etapa imprescindível no desenvolvimento do raciocínio multiplicativo, é importante investir, por meio do trabalho com uma grande variedade de problemas, na coordenação entre os esquemas (NUNES et al., 2009).

Até aqui se optou por não cindir a multiplicação e a divisão. Essa escolha foi fundamentada na compreensão de que, como componentes de um mesmo campo conceitual, tais operações apresentam ligações intrínsecas que devem ser consideradas, ainda que o interesse maior recaia sobre apenas uma delas. É necessário realçar, no entanto, que o foco dessa investigação foi a multiplicação e, portanto, foram consideradas apenas as situações de multiplicação (realçadas em cinza no Quadro 1), dentro de cada uma das categorias apresentadas, no esforço de atender aos objetivos da pesquisa. 


\section{CAPÍTULO 3}

\section{METODOLOGIA}

Este capítulo destina-se a descrever como a pesquisa foi conduzida. Aqui estão explicitados o local de fala da pesquisadora, bem como o desenho metodológico do trabalho desenvolvido com todos os recursos utilizados para atender aos objetivos previamente estabelecidos.

\subsection{O Local de Fala}

Denzin e Lincoln (2006) apontam que os pesquisadores são guiados por paradigmas que combinam crenças sobre ontologia, epistemologia e metodologia. Esses pressupostos fazem-se presentes desde a concepção do problema de pesquisa. Como bem exemplifica Sánchez Gamboa (2012) "uma pedra é um problema dentro do sapato, pode não sê-lo fora dele" (p.120), ou seja, um problema se configura como tal dentro uma rede específica de crenças e valores, que deixará suas marcas ao longo de todo o processo de pesquisa.

Zanella et al. (2007) apontam a necessidade de que os pesquisadores explicitem em seu trabalho esse lugar teórico, uma vez que isso contribui "para a localização tanto de quem fala quanto de quem escuta em relação ao que é dito e silenciado" (p. 26).

O trabalho de pesquisa aqui descrito percebe o professor como um sujeito ativo, que lida com as contradições entre demandas externas - ditadas por prescrições curriculares, materiais didáticos, avaliação em larga escala, dentre outros - e as necessidades e condições materiais do seu contexto de atuação dentro dos limites de sua formação e constituição enquanto profissional. É por isso que, apesar do interesse em compreender o objeto a partir do ponto de vista dos professores, suas percepções e concepções, a pesquisa extrapola o nível do sujeito.

Um outro pressuposto norteador da investigação foi o de que falar em currículo sem considerar os conflitos de interesses que o moldaram ao longo 
da história e que se fazem, ainda hoje, fortemente presentes, esvaziaria 0 objeto e comprometeria a relevância da pesquisa.

A pesquisa, portanto, identificou-se com a abordagem histórico-dialética, que compreende a educação como "uma prática inserida no contexto das formações sociais que resulta de condicionamentos sociais, políticos e econômicos" (FIORENTINI e LORENZATO, 2012) e que está, portanto, em movimento.

\subsection{Desenho Metodológico}

Considerando os pressupostos desta pesquisa, suas características, bem como os objetivos traçados, foi coerente vinculá-la à abordagem qualitativa. A abordagem qualitativa admite e valoriza o potencial do campo empírico para surpreender o pesquisador. O confronto com o desconhecido faz com que diversas idas e vindas sejam necessárias ao longo desse processo. Isso confere à pesquisa qualitativa um caráter circular, em contraponto ao modelo linear geral de pesquisa (FLICK, 2009). Tal característica "obriga o pesquisador a refletir permanentemente sobre todo o processo de pesquisa e sobre etapas específicas à luz de outras etapas" (FLICK, 2009, p.98), admitindo a interdependência entre elas.

A pesquisa aqui proposta se comprometeu com a reflexão constante, com o esforço de enxergar as complexas tramas entre as etapas da pesquisa e os pressupostos que as suportam, entendendo que este é um exercício indispensável para chegar a um todo coerente.

\subsubsection{Contexto da pesquisa}

A pesquisa esteve inserida no contexto do primeiro ciclo dos anos iniciais do Ensino Fundamental em uma escola pública do Distrito Federal. A opção pela rede pública de ensino justificou-se uma vez que esse é o espaço de ação das políticas públicas que incidem sobre a prescrição curricular, 
avaliação, fornecimento de livros didáticos e avaliação externa aqui investigadas.

Já o foco no primeiro ciclo dos anos iniciais foi motivado pelo interesse no trabalho de introdução das diversas ideias da multiplicação. A compreensão da diversidade conceitual inerente às operações básicas desde a sua introdução vem sendo apontada como fundamental para evitar a cristalização de equívocos conceituais (GITIRANA et al., 2014).

Nas Unidades Escolares da Secretaria de Estado de Educação do Distrito Federal (SEEDF), esse primeiro ciclo corresponde ao Bloco Inicial de Alfabetização (BIA). O BIA, instituído em 2007, veio em complementação ao estabelecimento do Ensino Fundamental de 9 anos. Implementado inicialmente na Coordenação Regional de Ceilândia em 2005, a nova duração do Ensino Fundamental já vigorava nas 697 unidades escolares que compõem as 14 Coordenações Regionais de Ensino da SEEDF em 2009.

Organizado enquanto ciclo de aprendizagem, o BIA adota a progressão continuada e, portanto, não há retenção dos alunos ao longo desses três anos. Esse período é dedicado à construção da proficiência leitora e escritora, apoiando-se na tríade alfabetização, letramentos e ludicidade (GDF, 2012).

O destaque para a alfabetização em língua materna não se restringe ao nome concedido ao bloco dos anos iniciais. Nessa organização, as diversas áreas do conhecimento são valorizadas enquanto espaços de letramento, mas suas especificidades ficam em segundo plano. A matemática, diferente das demais áreas, é abordada em um tópico específico do documento que estabelece as diretrizes do BIA (GDF, 2012). Tal concessão, no entanto, é justificada, no documento, pela característica "fascinante" da questão linguística no ensino da matemática (GDF, 2012, p. 34) reforçando, dessa forma, a submissão à alfabetização em língua materna.

A pesquisa, portanto, desenvolveu-se em um contexto de organização do trabalho pedagógico fortemente voltado para a alfabetização em língua materna no qual a matemática, apesar de ter um espaço mais consolidado em 
comparação com as demais áreas do conhecimento, não assume protagonismo.

\subsubsection{Cenário da pesquisa}

A investigação teve como cenário uma escola pública do Distrito Federal. A opção por uma única escola apoiou-se no caráter qualitativo da pesquisa que não teve como objetivo a comparação entre casos e experiências distintas e não vislumbrou generalizações - senão as naturalísticas, que ocorrem pela associação das informações fornecidas pelo estudo com aquelas que derivam da experiência pessoal dos leitores (LÜDKE e ANDRÉ, 1986).

O primeiro critério estabelecido para a definição da escola participante foi o da conveniência geográfica para a pesquisadora. $O$ interesse, nesse caso, recaiu prioritariamente sobre as unidades escolares vinculadas às Coordenações Regionais do Plano Piloto e Guará.

O Índice de Desenvolvimento da Educação Básica (Ideb) registrado pelas escolas em 2013 também constituiu um critério para a definição do lócus de pesquisa. A preferência foi pelas escolas que alcançaram os mais altos índices dentro da Coordenação Regional de Ensino selecionada. Isso porque se partiu do pressuposto de que, uma vez que o cálculo desse indicador contempla os resultados do Sistema de Avaliação da Educação Básica (Saeb), o destaque positivo da escola poderia estar relacionado a uma maior familiaridade com as avaliações em larga escala, o que seria positivo para a investigação uma vez que os professores poderiam ter percepções mais conscientes a respeito da influência desses instrumentos em suas práticas.

Por fim, a seleção do cenário de pesquisa esteve condicionada ao interesse da instituição. Considerando que a investigação não oferece vantagens claras e imediatas aos participantes e que, em acréscimo, constitui uma ruptura para o sistema a ser estudado, acreditou-se que o interesse poderia ser um fator de aproximação capaz de dispor os participantes a desenvolver confiança na pesquisadora de forma a forjar a aliança de trabalho 
necessária para a pesquisa (FLICK, 2012). Esses critérios conduziram a pesquisa a uma Escola Classe no Guará.

\subsubsection{Participantes da pesquisa}

Participaram da pesquisa duas professoras que atuam no $3^{\circ}$ ano do Ensino Fundamental na escola selecionada. $\mathrm{O}$ ano final do ciclo foi eleito como foco de interesse porque, a partir dele, é possível vislumbrar um panorama geral de como - e se - as diferentes ideias da multiplicação são introduzidas e trabalhadas ao longo desse período.

O $3^{0}$ ano do Ensino Fundamental é também o alvo da Avaliação Nacional da Alfabetização que será analisada, aqui, enquanto expressão do currículo avaliado.

Com a anuência prévia da equipe gestora, o convite para a participação na pesquisa foi feito às professoras de todas as cinco turmas de $3^{\circ}$ ano ativas na escola. Uma delas recusou imediatamente por não se sentir à vontade com as gravações em áudio e vídeo. Outras duas docentes que, a princípio, haviam manifestado interesse, também declinaram o convite posteriormente.

O número de participantes foi, então, reduzido a duas professoras: P1 e $\mathrm{P} 2$, que aderiram à pesquisa voluntariamente, segundo o disposto no termo de consentimento livre e esclarecido (APÊNDICE A). Ambas são professoras efetivas da SEEDF, condição que foi considerada favorável à pesquisa uma vez que poderia significar maior familiaridade com os documentos curriculares investigados.

P1 e P2 são professoras experientes: a primeira atua como docente há 29 anos, 19 deles dedicados à alfabetização, a segunda, de forma semelhante, conta com 27 anos de docência, com 26 em turmas de alfabetização. As duas participantes cursaram, além do magistério e da graduação, uma especialização. No que diz respeito à formação específica na área de Educação Matemática, ambas participaram de ações formativas no âmbito do 
PNAIC e P2 declarou ter realizado também cursos específicos ofertados pela própria SEEDF.

A construção das informações para atender aos objetivos propostos se deu pela associação de análise documental e entrevistas semiestruturadas. Inicialmente descritas de forma independente, as informações recolhidas a partir dessas duas vias foram analisadas conjuntamente de forma a contemplar o objetivo geral da pesquisa.

\subsubsection{Análise documental}

Dentre os quatro níveis do currículo que constituíram alvo de interesse desta pesquisa, três deles foram representados por documentos: o currículo prescrito, o currículo avaliado e o apresentado aos professores.

Como apontado por Lüdke e André (1986), a escolha dos documentos não é aleatória, mas guiada por propósitos, ideias ou hipóteses. Os pressupostos que guiaram a seleção dos materiais que compuseram o corpus documental analisado são apresentados a seguir.

O Currículo em Movimento é a prescrição curricular vigente no Distrito Federal. Apesar de existirem documentos federais, que podem ser entendidos como currículo prescrito, optou-se por utilizar a prescrição distrital, pois se acredita que este documento aproxima as diretrizes nacionais de seu contexto mais específico e, portanto, está mais próximo ao cenário da pesquisa.

No âmbito do currículo avaliado, o interesse recaiu, nesta pesquisa, sobre a avaliação em larga escala. Acredita-se que essa opção foi a mais adequada diante do interesse na compreensão da relação do professor com forças externas de determinação curricular.

O $3^{\circ}$ ano do Ensino Fundamental é avaliado pela ANA, que representou aqui esse nível do desenvolvimento curricular por meio de seu documento básico, matriz de referência para os testes de matemática e dos itens já utilizados em suas duas edições (2013 e 2014) ou aptos para utilização. O acesso aos itens e às informações estatísticas a eles relacionadas deu-se 
mediante autorização do Inep, responsável pela ANA, e com algumas limitações: as informações divulgadas não poderiam comprometer o sigilo desse material, conforme os termos do requerimento disponível no APÊNDICE B.

Já o currículo apresentado se fez presente em sua forma mais convencional: o livro didático. A pesquisa debruçou-se sobre o livro (manual do professor) da coleção Projeto Buriti Matemática - Alfabetização Matemática destinado ao $3^{\circ}$ ano do ensino fundamental em sua $3^{\mathfrak{a}}$ edição, disponibilizado por meio do PNLD para o triênio 2016/ 2017/ 2018 e adotado pela escola participante da pesquisa.

Os documentos foram submetidos à análise documental com vistas a atender os objetivos que se propõem a investigar a abordagem dada por esses materiais às situações multiplicativas. Lüdke e André (1986) apontam que a análise documental é uma forma de identificar informações factuais em documentos a partir das questões de interesse do pesquisador.

Ao questionar o documento, este deve ser entendido como um meio de comunicação: foi produzido por alguém, com alguma finalidade, destinado a algum público (FLICK, 2009). Essas características precisam ser desveladas e consideradas na análise desses materiais. Tais informações são especialmente relevantes se é pretendido superar a descrição, conferindo à análise um caráter crítico e, neste caso, também comparativo. É com esse intuito que foram adotados os procedimentos de análise documental apresentados por Cellard (2012).

O autor propõe dois momentos nesse processo: a análise preliminar e a análise em si. A análise preliminar consiste em uma avaliação crítica do documento considerando cinco dimensões: o contexto; a autoria; a natureza do texto; os conceitos-chave e a lógica interna do texto e, por fim, sua autenticidade e confiabilidade (CELLARD, 2012). No momento da análise, esses elementos são interpretados, em conjunto com o quadro teórico da pesquisa, considerando os questionamentos iniciais. O encadeamento de ligações entre eles, muitas vezes apoiado na sincronicidade, é que encaminha explicações plausíveis e interpretações coerentes (CELLARD, 2012). 


\subsubsection{Entrevistas semiestruturadas}

A entrevista pode ser caracterizada como uma "conversação dirigida a um propósito definido" (FRASER e GONDIM, 2004, p.139). O planejamento dessa etapa da pesquisa considerou que este é um momento de interação e, dessa forma, a atmosfera é de influência recíproca entre entrevistador e entrevistado, o que demanda esforços no sentido de construir um clima de estímulo e de aceitação mútua (LÜDKE e ANDRÉ, 1986).

Dentre os diversos estilos de entrevista possíveis, optou-se pela entrevista semiestruturada. Essa escolha está alinhada com a observação de Lüdke e André (1986) a respeito da maior adequação de um instrumento mais flexível para abordar as informações e informantes interessantes à pesquisa em educação.

A entrevista semiestruturada seguiu um roteiro de tópicos ou perguntas gerais (APÊNDICE C) elaborado a partir dos interesses da investigação e da revisão de literatura sobre o tema (FRASER e GONDIM, 2004). Esse esquema básico, no entanto, não era rígido e permitiu que a entrevistadora fizesse as adaptações que se mostraram necessárias (LÜDKE e ANDRÉ, 1986).

Destinadas aos professores participantes, as entrevistas foram concebidas, primordialmente, para construir informações que subsidiassem a análise das concepções desses sujeitos acerca do ensino e aprendizagem da multiplicação e das suas percepções a respeito da influência do livro didático, da avaliação em larga escala e do currículo oficial na prática docente. As entrevistas, portanto, forneceram as informações a respeito do currículo moldado pelos professores.

Como estratégia para distanciar a entrevista do caráter de teste, uma vez que a intenção não era testar os conhecimentos matemáticos do professor, foi adotado o uso de fichas (APÊNDICE D) como um complemento ao roteiro de entrevista. Foram preparadas fichas com diversas situações-problema semelhantes àquelas propostas pelo livro didático e pelos testes das avaliações em larga escala, contemplando as diferentes ideias da multiplicação. 
Às professoras participantes, foi solicitado que apontassem as situações-problema que acreditavam que seus alunos resolveriam com maior ou menor facilidade, além de indicar aquelas que selecionariam para suas aulas, justificando suas escolhas. A revisão de literatura leva a crer que essas informações têm o potencial para fornecer indícios a respeito da familiaridade do professor com a variedade de ideias relacionadas à multiplicação e sobre como esses conhecimentos se refletem no seu trabalho em sala de aula.

As informações provenientes das entrevistas foram registradas em áudio e vídeo e também por meio de anotações manuscritas. A filmagem foi, inicialmente, considerada necessária para a análise do trabalho com as fichas de situações-problema mas revelou-se dispensável, uma vez que as anotações se mostraram suficientes para o registro da atividade das professoras participantes. As gravações foram transcritas integralmente e então submetidas à análise de conteúdo.

\subsubsection{Análise de conteúdo}

Para fins de análise do material produzido pelas entrevistas, foi adotada a análise de conteúdo, apoiada em Bardin (2009). Chizzotti (2001) aponta que essa técnica se aplica à análise de textos escritos ou de qualquer comunicação (oral, visual, gestual) reduzida a um texto ou documento com o objetivo de compreender criticamente seu sentido, o conteúdo manifesto ou latente, as significações explícitas ou ocultas.

O analista infere conhecimentos sobre o emissor/receptor ou sobre o seu meio a partir do tratamento das mensagens (BARDIN, 2009). É pressuposto, portanto, que a emissão de mensagens está necessariamente articulada às condições contextuais de seus produtores (FRANCO, 2012). Essas condições contextuais, por sua vez, não se resumem no aqui e agora, mas são fruto de um longo, conflitivo e complexo processo histórico e social (FRANCO, 2012).

De acordo com Bardin (2009), é a inferência que permite a passagem, explícita e controlada, da descrição à interpretação. O sucesso dessas operações, no entanto, não está baseado em uma receita universal, já que se 
trata de um método muito empírico, mas conta com algumas regras de base (BARDIN, 1977).

Dentre essas regras de base apresentadas por Bardin (2009), Triviños (1987) identifica três etapas principais: a pré-análise, a descrição analítica e a interpretação inferencial. É importante salientar que essas etapas não se dão de forma estanque. As atividades de uma permeiam as outras.

A pré-análise corresponde à organização do material. Nessa etapa, o pesquisador se valerá da leitura flutuante para formular os objetivos gerais e hipóteses amplas da pesquisa e determinar o corpus da investigação (TRIVINÕS, 1987). A descrição analítica pressupõe um estudo aprofundado do corpus orientado pelas hipóteses e referenciais teóricos além dos procedimentos de codificação, classificação e categorização (TRIVINÕS, 1987). Já a interpretação inferencial consiste no aprofundamento das conexões das ideias por meio da reflexão e intuição embasadas nos materiais empíricos que permitem superar o conteúdo manifesto e desvendar o conteúdo latente (TRIVINÕS, 1987).

A análise de conteúdo, na pesquisa proposta, seguiu um viés qualitativo. Nessa abordagem, recorre-se a índices não frequenciais que permitam inferências: a presença ou a ausência, por exemplo (BARDIN, 2009). A análise qualitativa requer sucessivas aproximações ao material e admite que as hipóteses inicialmente formuladas podem sofrer alterações ao longo do procedimento, influenciadas pelas compreensões que 0 analista constrói (BARDIN, 2009).

Os frutos do caminho metodológico aqui descritos são apresentados nessa dissertação da seguinte forma: um capítulo, destinado aos resultados, fornece a descrição dos documentos e das entrevistas e, no capítulo seguinte, é apresentada a análise desses materiais a partir de categorias de convergência entre eles. Essas categorias foram definidas de forma a contemplar cada uma das ideias da multiplicação aqui discutida (multiplicação comparativa, proporcionalidade, configuração retangular e combinação) e também os aspectos didáticos que permearam os materiais analisados. 


\section{CAPÍTULO 4}

\section{RESULTADOS}

Este capítulo está comprometido com a exposição dos materiais que comporão a análise (documento e entrevistas) a partir de um olhar orientado pelos objetivos da pesquisa. Neste ponto, assume caráter meramente descritivo, servindo como subsídio à análise que se segue.

\subsection{O Currículo em Movimento}

O Currículo em Movimento da Educação Básica define a base comum para o ensino nas escolas públicas do Distrito Federal. Aprovado em 2013, o documento ganhou forma por meio de uma construção coletiva: ao longo de dois anos, professores, estudantes, coordenadores e gestores se dedicaram a estudar, discutir e reformular a proposta preliminar a eles apresentada pela SEEDF (GDF, 2013b).

Desse esforço, resultaram oito cadernos que se referem às diferentes etapas e modalidades da educação básica. São eles: Pressupostos Teóricos; Educação Infantil; Ensino Fundamental - Anos Iniciais; Ensino Fundamental Anos Finais; Ensino Médio; Educação Profissional e a Distância; Educação de Jovens e Adultos e Educação Especial. Para atender ao interesse da pesquisa, a análise documental teve como insumo o caderno destinado aos anos iniciais do Ensino Fundamental (GDF, 2013a) e considerou também os pressupostos teóricos da proposta (GDF, 2013b) de forma a contextualizá-la.

O Currículo em Movimento declara apoiar-se nas perspectivas Crítica e Pós-Crítica de currículo para situar-se teoricamente. Enquanto a Teoria Crítica é vista como um recurso para desnaturalizar as desigualdades sociais e a neutralidade do conhecimento e comprometer a educação com a transformação social, a Teoria Pós-Crítica é a responsável por estabelecer as conexões com o multiculturalismo (GDF, 2013b).

O documento propõe a integração curricular, referenciando para isso o trabalho de Santomé (1998). A proposta é que essa integração se dê por meio 
do trabalho interdisciplinar sustentado por eixos transversais - educação para a diversidade, educação para a cidadania, educação para a sustentabilidade e educação para e em direitos humanos - e eixos integradores - alfabetização (somente para os três primeiros anos do Ensino Fundamental), letramento e ludicidade (para todo o Ensino Fundamental) (GDF, 2013b).

É notável, no entanto, que enquanto os eixos transversais são explorados ao longo de vinte e oito páginas no caderno destinado à apresentação dos pressupostos teóricos do Currículo em Movimento, aos eixos integradores são dedicados dois parágrafos no caderno dos anos iniciais do Ensino Fundamental.

O Currículo em Movimento reconhece suas limitações enquanto prescrição e, por isso, proclama a flexibilidade como um de seus princípios. $O$ documento, em inúmeros momentos, admite e valoriza a ação docente sobre o currículo por meio do Projeto Político Pedagógico. É verdade, porém, que essa flexibilidade é relativizada no texto, que deixa transparecer a preocupação com o cumprimento integral da base apresentada.

O caderno Ensino Fundamental - Anos Iniciais apresenta prescrições para as áreas de Linguagens; Matemática; Ciências Humanas; Ciências da Natureza e Ensino Religioso.

A proposta para a área de Matemática declara apoio aos ideais da Educação Matemática assumindo, portanto, uma prática pedagógica que promova o gosto pela aprendizagem da Matemática e reconheça a criança como construtora do conhecimento e capaz, também, de produzi-lo. A orientação é que a organização do trabalho pedagógico em sala de aula favoreça a problematização de forma a levar o aluno a aprender a pensar matematicamente. O professor deve, ainda, dedicar-se a promover a interação dos conteúdos matemáticos entre si e com outras áreas do saber.

Os conteúdos e objetivos de aprendizagem de Matemática são agrupados em cinco blocos: Números e Operações, Geometria, Grandezas e Medidas; Tratamento da Informação e Estruturas Lógicas ou Processos Mentais, que perpassa os demais blocos. Essa categorização é vista como um 
recurso para facilitar a exposição daquilo que deve ser trabalhado nos anos iniciais e a recomendação é que o professor promova não só a interação entre blocos, mas também entre as áreas do saber (GDF, 2013a).

As reflexões tecidas pelo documento a respeito do bloco Números e Operações apontam a necessidade de oferecer aos alunos situações-problema que envolvam as diferentes ideias relacionadas às operações aritméticas, quais sejam:

QUADRO 2 - Ideias associadas às operações aritméticas na proposta do Currículo em Movimento

\begin{tabular}{|l|l|}
\hline \multicolumn{1}{|c|}{ OPERAÇÃO ARITMÉTICA } & \multicolumn{1}{c|}{ CONCEITO } \\
\hline Adição & Juntar e acrescentar \\
\hline Subtração & Retirar, completar e comparar \\
\hline Multiplicação & $\begin{array}{l}\text { Repetição de parcelas iguais, combinação } \\
\text { e representação retangular }\end{array}$ \\
\hline Divisão & Partilha e medida \\
\hline
\end{tabular}

Fonte: GDF (2013a)

Os conceitos relacionados à multiplicação, foco desta pesquisa, são assim exemplificados pelo Currículo em Movimento:

- Repetição de parcelas iguais: Tenho 3 notas de $R \$ 2,00$. Quanto tenho?

- Combinação: Tenho uma calça preta e outra azul para combinar com uma blusa branca, outra vermelha e outra amarela. Quantas combinações diferentes posso fazer?

- Representação retangular: Numa caixa de ovos há 5 fileiras com 6 ovos. Quantos ovos há na caixa?

De acordo com o documento, o trabalho docente nesse âmbito não deve impor modos de fazer, mas dar espaço para a criatividade e autonomia do estudante e então, num momento posterior, "o modelo da escola pode ser apresentado como mais uma das formas de resolver, mas não a única" (GDF, 2013a, p.73). 
Dois quadros sistematizam os objetivos e conteúdos de Matemática para os anos iniciais. O primeiro reúne as prescrições para o BIA, ciclo de aprendizagem composto pelos três primeiros anos do Ensino Fundamental, e o segundo refere-se ao segundo bloco, que agrupa o $4^{\circ}$ e $05^{\circ}$ ano do Ensino Fundamental.

Os quadros exibem, lado a lado, os conteúdos para os diferentes anos escolares a que se destinam, de forma a evidenciar a progressão desejada. Os cabeçalhos retomam os eixos transversais e integradores a serem considerados em cada ciclo. Essa disposição pode ser observada a seguir: 
QUADRO 3 - Objetivos e conteúdos do Currículo em Movimento

\begin{tabular}{|c|c|c|c|c|c|}
\hline \multicolumn{6}{|c|}{$\begin{array}{r}\text { EIXOS TRANSVERSAIS: EDUCAÇÃO PARA A DIVERSIDADE / CIDADANIA E EDUCAÇÃO EM E } \\
\text { HUMANOS / EDUCAÇÃO PARA A SUSTENTABILIDADE }\end{array}$} \\
\hline \multicolumn{6}{|c|}{$\begin{array}{c}\text { EIXOS INTEGRADORES - ALFABETIZAÇÃO/LETRAMENTOS/LUDICIDADE } \\
\text { MATEMÁTICA } \\
\text { BLOCO INICIAL DE ALFABETIZAÇÃO - BIA }\end{array}$} \\
\hline \multicolumn{2}{|c|}{$1^{\circ}$ ANO } & \multicolumn{2}{|c|}{$2^{\circ}$ ANO } & \multicolumn{2}{|c|}{$3^{\circ}$ ANO } \\
\hline OBJETIVOS & CONTEÚDO & OBJETIVOS & CONTEÚDO & OBJETIVOS & CONTEÚDO \\
\hline $\begin{array}{l}\text { Estruturas lógicas ou } \\
\text { processos mentais } \\
\text { - Vivenciar situaçōes } \\
\text { que envolvam } \\
\text { estruturas lógico- } \\
\text { matemáticas. } \\
\text { - Adquirir noçōes } \\
\text { de conservação, } \\
\text { correspondência, } \\
\text { comparaçăo, } \\
\text { classificaçăo, } \\
\text { ordenaçăo e } \\
\text { sequenciaçăo. }\end{array}$ & $\begin{array}{l}\text { Estruturas lógicas ou } \\
\text { processos mentais } \\
\text { - Estruturas lógico- } \\
\text { matemáticas } \\
\text { (processos mentais): } \\
\text {-Conservação } \\
\text {-Correspondência } \\
\text {-Comparação } \\
\text {-Classificação } \\
\text {-Sequenciaçăo } \\
\text {-Seriação } \\
\text {-Ordenaçào } \\
\text {-Inclusaao }\end{array}$ & $\begin{array}{l}\text { Estruturas lógicas ou } \\
\text { processos mentais } \\
\text { - Utilizar critérios } \\
\text { de classificaçăo, } \\
\text { conservaçăo, } \\
\text { correspondência, } \\
\text { comparaçăo, } \\
\text { sequênciaçăo, seriação, } \\
\text { ordenaçăo e inclusăo. } \\
\end{array}$ & $\begin{array}{l}\text { Estruturas lógicas ou } \\
\text { processos mentais } \\
\text { - Estruturas lógico- } \\
\text { matemáticas } \\
\text { (processos mentais): } \\
\text {-Conservação } \\
\text {-Correspondência } \\
\text {-Comparação } \\
\text {-Classificaçăo } \\
\text {-Sequenciação } \\
\text {-Seriação } \\
\text {-Ordenação } \\
\text {-Inclusão }\end{array}$ & $\begin{array}{l}\text { Estruturas lógicas ou } \\
\text { processos mentais } \\
\text { |. Consolidar critèrios } \\
\text { de classificaçăo, } \\
\text { | conservaçăo, } \\
\text { correspondência, } \\
\text { comparaçăo, } \\
\text { |classificaçăo, } \\
\text { sequenciaçăo, seriaçào, } \\
\text { ordenaçăo e inclusảo. }\end{array}$ & $\begin{array}{l}\text { Estruturas lógicas ou } \\
\text { processos mentais } \\
\text { - Estruturas lógico- } \\
\text { matemáticas } \\
\text { (processos mentais): } \\
\text {-Conservação } \\
\text {-Correspondência } \\
\text {-Comparação } \\
\text {-Classificação } \\
\text {-Sequenciaçăo } \\
\text {-Seriaçào } \\
\text {-Ordenação } \\
\text {-Inclusão }\end{array}$ \\
\hline
\end{tabular}

Fonte: GDF (2013a) 
A apresentação dos conteúdos respeita a organização em blocos previamente introduzida. Não há indicações de divisão por bimestre já que "todos os blocos devem tratados em todos os bimestres, com objetivos diferentes" (GDF, 2013a, p.68).

No que diz respeito ao foco desta pesquisa, a multiplicação no $3^{\circ}$ ano do Ensino Fundamental, o documento prescreve os seguintes objetivos e conteúdos:

QUADRO 4 - Objetivos e conteúdos relacionados à multiplicação

\begin{tabular}{|c|c|}
\hline \multicolumn{2}{|c|}{ 3 ANO } \\
\hline OBJETIVOS & CONTEÚDOS \\
\hline $\begin{array}{l}\text { - Compreender e aplicar diferentes ideias de } \\
\text { multiplicação: repetição de parcelas iguais, } \\
\text { combinação e configuração retangular } \\
\text { através da resolução de situações- } \\
\text { problema com registros pictóricos e } \\
\text { numéricos. } \\
\text { - Resolver situações-problema significativas } \\
\text { de adição, subtração, multiplicação e } \\
\text { divisão, envolvendo as diferentes ideias } \\
\text { através de registros pictóricos, orais e ou } \\
\text { escritos das experiências matemáticas } \\
\text { vivenciadas a partir de jogos, brincadeiras } \\
\text { etc. }\end{array}$ & $\begin{array}{l}\text { - Multiplicação (ações de agrupar parcelas } \\
\text { iguais, combinações, proporcionalidade e } \\
\text { disposição retangular). } \\
\text { - Formulação, interpretação e resolução de } \\
\text { situações-problema envolvendo noções de } \\
\text { adição (ações de juntar, acrescentar), } \\
\text { subtração (ações de retirar, comparar e } \\
\text { completar), multiplicação (soma de parcelas } \\
\text { iguais e combinação associada à tabela de } \\
\text { dupla entrada, à superfície. Exemplo: formar } \\
\text { um retângulo 3x4) e divisão (ações de } \\
\text { partilha e de medida) explorando a } \\
\text { diversidade de procedimentos e de } \\
\text { registros. } \\
\text { - Fatos fundamentais da adição, subtração e } \\
\text { da multiplicação em situações significativas } \\
\text { que desenvolvam o cálculo mental, cálculo } \\
\text { aproximado, estimativa, socialização de } \\
\text { estratégias de conferência. }\end{array}$ \\
\hline
\end{tabular}

Fonte: GDF (2013a, grifo nosso)

Cabe notar que os conteúdos previstos para o $3^{\circ}$ ano do E.F. fazem referência à ideia de proporcionalidade (destacada no Quadro 4). Esta interpretação da multiplicação, no entanto, não é introduzida previamente pelo 
documento e nem são fornecidos exemplos de situações desse tipo que permitam caracterizá-la.

\subsection{O Livro Didático}

A escola participante trabalha com a coleção Projeto Buriti Matemática Alfabetização Matemática. Os livros didáticos que a compõem são obras coletivas concebidas, desenvolvidas e produzidas pela Editora Moderna. Para o interesse desta pesquisa, foi analisado o livro destinado ao 3ํano do Ensino Fundamental (manual do professor) em sua $3^{\text {a }}$ edição, disponibilizada por meio do PNLD para o triênio 2016/ 2017/ 2018.

A coleção Projeto Buriti Matemática - Alfabetização Matemática declara conceber o livro didático como um suporte, defendendo a autonomia do professor enquanto mediador do conhecimento.

O material também assume um compromisso com a interdisciplinaridade, entendida como o estabelecimento de "relações entre as disciplinas para além da mera justaposição, mas aquém de uma fusão e, consequentemente, da desintegração do saber disciplinar" (MODERNA, 2014, p. 312). Para isso, procura articular o saber matemático com situações cotidianas de forma que as atividades sugeridas "acrescentem novas possibilidades na integração de conceitos, proporcionando-lhe [ao professor] uma visão mais clara do diálogo entre as áreas que compõem o currículo escolar" (MODERNA, 2014, p.311). Na apresentação do livro, é informado também que as seções $A$ Matemática me ajuda a ser... e Matemática em textos são os espaços dos temas transversais, abordados em uma perspectiva interdisciplinar.

Os objetivos da formação básica determinados pelas Diretrizes Curriculares Nacionais Gerais para a Educação Básica (BRASIL, 2010) e os objetivos do ensino de Matemática para os primeiros anos do Ensino Fundamental definidos pelos PCN (BRASIL, 1997) são apontados como orientadores da coleção. Outros documentos oficiais, como os cadernos do 
PNAIC (BRASIL, 2013a) e do Pró-Letramento (BRASIL, 2008a), também são utilizados para fundamentar a proposta desse material.

Também com base nos PCN e pesquisas na área, é adotada a organização dos conteúdos matemáticos em quatro blocos - Números e operações, Espaço e forma, Tratamento da informação e Grandezas e medidas. Essa classificação tem como objetivo garantir que todos esses blocos tenham espaço na sala de aula, sendo trabalhados de forma articulada não só entre eles, mas também com outras áreas do conhecimento.

Esses blocos são abordados de forma integrada ou intercalada ao longo das 9 unidades que compõem o livro analisado. A resenha fornecida pelo Guia de Livros Didáticos do PNLD (BRASIL, 2015) - que usa a denominação Geometria de forma equivalente a Espaço e forma - informa a seguinte distribuição dos campos da matemática escolar no exemplar:

FIGURA 1 - Gráfico da distribuição dos campos da matemática escolar no Projeto Buriti - Alfabetização Matemática - $3^{\circ}$ ano

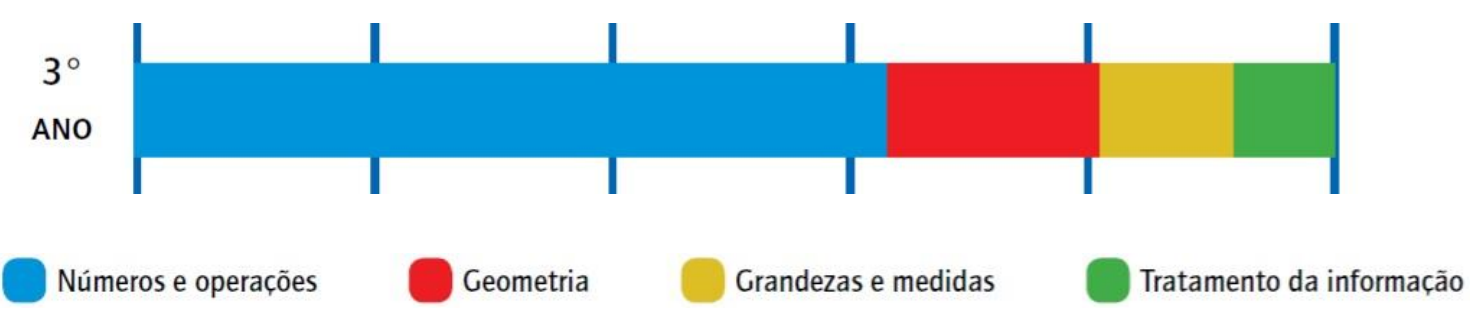

Fonte: Brasil (2015)

O manual do professor oferece orientações específicas para o trabalho em cada uma das unidades. Nesse espaço, o professor tem acesso a comentários sobre as atividades e orientações para conduzi-las, além de sugestões de leituras e vídeos relacionados ao conteúdo em questão que podem contribuir para a ampliação dos seus conhecimentos.

O campo multiplicativo é a temática de duas unidades, uma delas dedicada exclusivamente à multiplicação e outra na qual é acrescentada a divisão.

A Unidade 5 - Multiplicação é composta pelos seguinte tópicos de conteúdo: Adição de parcelas iguais/ Disposição retangular/ Combinando 
possibilidades/ Mais multiplicação/ 2 vezes ou o dobro/ 3 vezes ou o triplo/ 4 vezes ou o quádruplo/ 5 vezes/ 6 vezes/ 7 vezes/ 8 vezes/ 9 vezes/ 10 vezes/ Atividades/ 2 vezes e vezes 2; 3 vezes e vezes 3.../ Termos da multiplicação/ Jogo: UM, DOIS E JÁ!/ Compreender problemas/ Compreender informações/ A matemática me ajuda a ser.../ Para terminar (MODERNA, 2014, p.7).

A unidade é introduzida pela seguinte imagem, que contextualiza uma série de questionamentos que se relacionam com as diferentes ideias da multiplicação: 
FIGURA 2 - Abertura da Unidade 5: Multiplicação

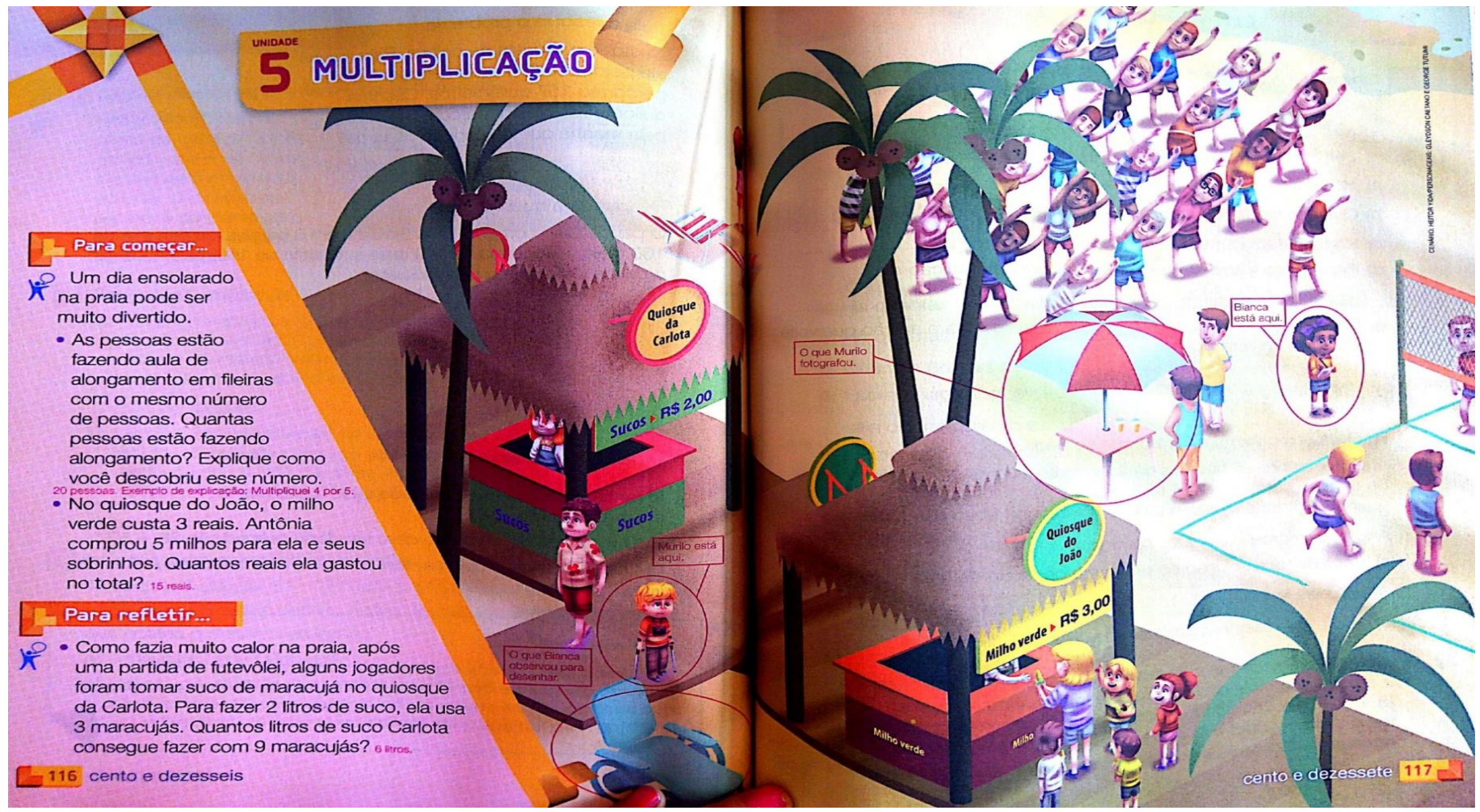

Fonte: Moderna (2014) 
A partir de então, essas ideias vão sendo apresentadas separadamente. A primeira delas é a denominada adição de parcelas iguais. Para explorar essa categoria, são propostos três exercícios que envolvem situações do tipo "Ângelo comprou 5 pacotes de figurinhas. Se cada pacote contém 4 figurinhas, quantas figurinhas ele comprou?" (MODERNA, 2014, p.118), sempre solicitando, primeiramente, a representação por uma adição e, depois, pela multiplicação correspondente. Em apenas uma das situações o estudante pode contar com o apoio de imagem. As orientações fornecidas para o professor ressaltam a importância de que os alunos percebam que, nessa interpretação, multiplicador e multiplicando têm papéis diferentes e que a inversão destes, embora não altere o resultado, gera uma representação diversa. Também é recomendado que os alunos tenham a oportunidade de explorar estratégias próprias de pensamento, com destaque para os desenhos.

Em seguida, são dedicados dois exercícios para trabalhar a associação da multiplicação à disposição retangular. Ambos, com o suporte de imagens, procuram levar o estudante à estratégia de multiplicar a quantidade de linhas pela quantidade de colunas - termos que devem ser diferenciados -, ou viceversa, para encontrar o total de elementos no conjunto apresentado. O material também busca evidenciar que, nesses casos, a ordem dos fatores não é significativa: qualquer um dos dados pode ser assumido como multiplicando ou multiplicador. O livro aponta que essa interpretação da multiplicação promove um primeiro contato com a ideia de área.

Em combinando possibilidades são oferecidas três situações nos seguintes moldes: "Clara ganhou uma boneca de presente. Acompanham a boneca 2 vestidos e 3 pares de sapatos [...] De quantas formas diferentes é possível vestir a boneca de Clara?" (MODERNA, 2014, p.121). Essa ideia da multiplicação é considerada um "primeiro passo em direção ao campo da análise combinatória” (MODERNA, 2014, p.397). É notável que, a princípio, os questionamentos dizem respeito a quais são as possibilidades $e$, posteriormente, avançam para quantas elas são, estabelecendo, então, 0 vínculo com a multiplicação. Em todos os problemas propostos, os dados estão representados em imagens. Nas orientações específicas alerta-se que, na faixa etária em questão, é comum que os estudantes recorram a estratégias 
próprias, apoiando o raciocínio em representações gráficas - a tabela é então apresentada como uma possível estratégia de sistematização. Nesse ponto, ao apresentar a sugestão de leitura para o professor, o material reconhece a Teoria dos Campos Conceituais como "fundamentação teórica da proposta atual de ensino da multiplicação e da divisão" (MODERNA, 2014, p. 398).

No tópico seguinte, intitulado Mais multiplicação, são apresentados cinco problemas, ilustrados, semelhantes a "Se 2 canetas custam, juntas, 3 reais, qual é o preço de 4 dessas canetas?" (MODERNA, 2014). O encarte de orientações e subsídios ao professor classifica tais situações dentro da ideia de proporcionalidade, e aponta que esse raciocínio "sustenta um grande número de procedimentos matemáticos na Aritmética e na Geometria, e sua compreensão facilita a extensão dessas estratégias de cálculo a diferentes contextos". Esse material esclarece ainda que foram priorizados os contextos culinário e de comércio por serem esses os "problemas típicos desse campo matemático" (MODERNA, 2014, p.399). Mais uma vez, é chamada a atenção para a importância dos registros, uma vez que a análise destes pelo professor permite conhecer as estratégias utilizadas pelos alunos.

Em seguida, o livro oferece atividades para exercitar os cálculos das multiplicações do tipo 2 vezes, 3 vezes, 4 vezes, ..., 10 vezes. Nessa oportunidade, são introduzidas as nomenclaturas dobro, triplo, quádruplo e quíntuplo. A estratégia de apoiar-se na adição para chegar à multiplicação não é abandonada: pede-se, primeiro, a representação por uma adição e, então, pela multiplicação correspondente. O material de apoio justifica que a escrita aditiva "facilita a obtenção dos resultados e a verificação da compreensão do significado de cada multiplicação" (MODERNA, 2014, p.403).

As atividades propõem também a comparação entre as "listas de multiplicações" - comumente denominadas tabuadas -, que devem ser completadas pelos alunos. Por esse meio, busca-se promover a apreensão da existência de números que são múltiplos de mais de um número e também da propriedade comutativa que, de acordo com as orientações para o professor, não precisa ser enunciada aos alunos, bastando que sua veracidade seja percebida. Espera-se que a observação dessas listas revele ainda outras 
regularidades, tais como: a multiplicação do tipo duas vezes ou dobro resulta em números pares; os resultados das multiplicações do tipo cinco vezes apresentam, alternadamente, os algarismos 5 e 0 na casa das unidades; na multiplicação do tipo dez vezes, o número que está sendo multiplicado é acrescido com o algarismo zero à direita.

Em Atividades os alunos dispõem de dois exercícios que retomam conteúdos da unidade: o primeiro aborda a multiplicação na disposição retangular com a sistematização de dados na tabela; no segundo as listas de multiplicação dos tipos vezes 5 e vezes 10 devem ser completadas e comparadas.

No tópico 2 vezes e vezes 2; 3 vezes e vezes 3 é explorada a comutatividade da multiplicação. Num primeiro momento, busca-se evidenciar que as multiplicações $2 \times 5$ e $5 \times 2$, por exemplo, têm o mesmo resultado, mas podem implicar em significados e representações diferentes. Então, passa-se a trabalhar com situações de multiplicação em disposição retangular já que, nessa interpretação, a inversão dos valores do multiplicador e do multiplicando não implica em prejuízo conceitual.

As orientações ao professor fornecidas pelo livro destacam que a compreensão dessa propriedade da multiplicação "facilita a memorização dos resultados das listas de multiplicações" já que "reduz pela metade o número de resultados a lembrar" (MODERNA, 2014, p.407). Sobre o valor que confere à automatização do conhecimento, o material esclarece que "não se trata, em hipótese alguma, de propor o ensino de conteúdos matemáticos através de exercícios de repetição. Trata-se, isto sim, de reconhecer que, depois de construído determinado conhecimento, pode ser absolutamente desejável que os alunos passem a ter acesso automático a ele" (MODERNA, 2014, p.320).

A unidade apresenta também os Termos da multiplicação. Para isso, oferece aos alunos, além de um esquema que identifica cada um dos termos, a seguinte conceitualização: "Os números usados em uma multiplicação são chamados de fatores. O resultado da multiplicação é chamado de produto." (MODERNA, 2014, p.136). O ensino dessa nomenclatura é considerado importante para facilitar a comunicação de ideias matemáticas. São dedicadas 
cinco atividades a este conteúdo. Uma delas requer que os alunos completem um quadro preenchendo as células com o produto das multiplicações dos fatores - números do 2 ao 10 - indicados pela linha e coluna que se cruzam neste ponto. $O$ material de apoio ao professor considera que a consulta a esse quadro facilita a percepção de regularidades e a memorização dos resultados. Ainda neste tópico de conteúdo, outro exercício busca levar os alunos às seguintes conclusões: quando um dos fatores é 0 , o produto será 0 ; quando um dos fatores é 1 , o resultado será igual ao outro fator.

Em seguida, é proposto um Jogo que requer que, sabendo um dos fatores e o produto, o aluno chegue ao outro fator envolvido na multiplicação. $O$ livro prevê duas estratégias que podem ser adotadas para isso: efetuar a divisão do produto pelo fator conhecido ou tentar diversas multiplicações até identificar a incógnita. O material de apoio ao professor aponta que o grande mérito desta atividade é "propiciar uma preparação para a ideia de que a divisão é a operação inversa da multiplicação" (MODERNA, 2014, p.408) e também promover a memorização dos resultados das listas de multiplicações, já que o jogo "permite que, em um contexto lúdico e motivador, os alunos recorram à memória ou reconstruam os resultados desses cálculos" (MODERNA, 2014, p.408). São oferecidas ainda cinco atividades relativas ao jogo que exploram os conceitos de produtos máximos e mínimos, produtos possíveis e impossíveis e retomam o princípio da comutatividade.

A seção Compreender problemas apresenta as subdivisões Para resolver e Para refletir. A primeira delas apresenta dois problemas que demandam a busca de dados em tabelas para sua resolução. O material entende que "a organização dos dados em tabelas facilita a observação de regularidades e a compreensão do cálculo proporcional" (MODERNA, 2014, p.409). Já em Para refletir são oferecidas quatro atividades que retomam esses problemas, incentivando a busca de novas soluções e a reflexão sobre as estratégias adotadas nesse processo.

O trabalho com tabelas continua em Compreender informações, seção dedicada à multiplicação como combinação. Aqui, a tabela é vista como uma estratégia para informar não somente quantas possibilidades de combinação 
existem, mas também quais são elas. O material de apoio ao professor recomenda que, nessa oportunidade, seja relembrada a característica fundamental das tabelas de dupla entrada: o preenchimento de cada célula deve considerar o cruzamento da informação da linha com a informação da coluna.

A matemática me ajuda a ser... traz como tema a prática esportiva e, por isso, sugere-se aos professores que promovam a interdisciplinaridade com a disciplina Educação Física. É apresentado um texto motivador acompanhado de questões que demandam o resgate de informações e também reflexões pessoais. Uma das atividades reforça a tabela como recurso de apoio à multiplicação pela sistematização dos dados. Por fim, a seção Para terminar oferece cinco atividades de revisão que contemplam uma variedade de situações estudadas ao longo da unidade.

A Unidade 7 - Multiplicação e divisão está estruturada da seguinte forma: Multiplicação por decomposição/ Algoritmo usual da multiplicação/ Mais multiplicação/ Atividades/ Divisão: repartir igualmente/ Divisão: quantas vezes cabe/ Divisão exata e divisão não exata/ Termos da divisão/ Divisões representadas na chave/ Divisão por estimativas/ Algoritmo usual da divisão/ Mais divisões/ Número par e número ímpar/ Problemas/ Compreender informações/ A matemática me ajuda a ser.../ Para terminar (MODERNA, 2014, p.7).

O material de apoio ao professor esclarece que a opção por abordar a multiplicação e a divisão conjuntamente em uma mesma unidade se deve ao "bom aproveitamento que os alunos dessa faixa etária costumam apresentar ao trabalhar com esses tópicos de forma inter-relacional" (MODERNA, 2014, p.426). Na abertura da unidade, é apresentada a Figura 3, que é explorada para gerar questionamentos que suscitam o uso da multiplicação e da divisão. A intenção é que os alunos utilizem conhecimentos prévios e estratégias próprias para apontar soluções. 
FIGURA 3 - Abertura da Unidade 6: Multiplicação e Divisão

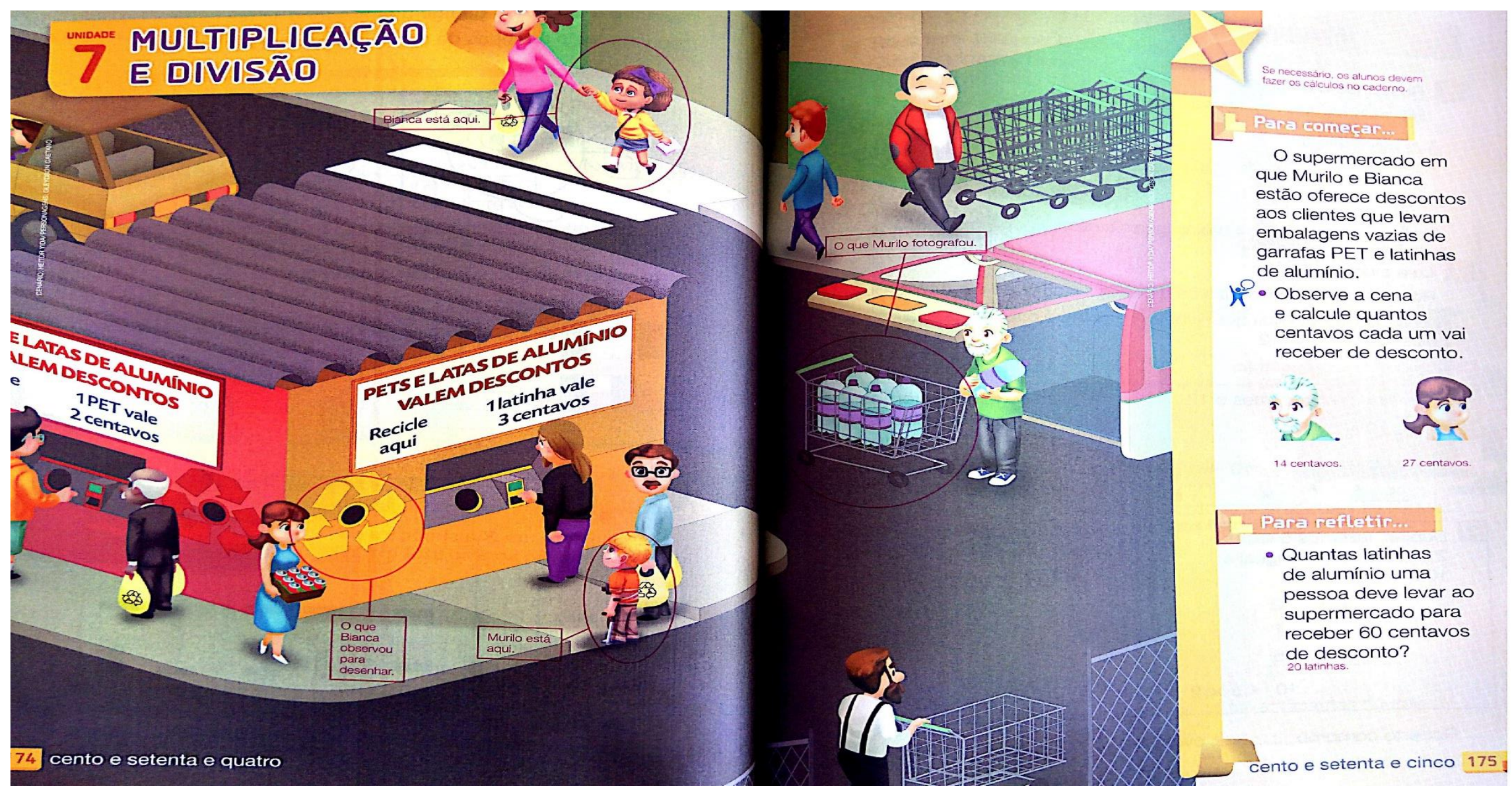

Fonte: Moderna (2014) 
O primeiro tópico da unidade apresenta a estratégia de multiplicação por decomposição. Para isso, é fornecido um esquema que detalha os procedimentos necessários - decomposição do número a ser multiplicado, realização da multiplicação por cada uma das parcelas separadamente e posterior soma dos resultados encontrados - e outros três exercícios que contemplam a ideia de multiplicação como adição de parcelas iguais e têm um dos fatores maior que 10. As orientações para os professores preveem o recurso a diferentes estratégias por parte dos alunos e recomendam a socialização destas para enfatizar a propriedade distributiva da multiplicação em relação à adição a partir da percepção de que, mesmo decompondo o número de formas diferentes, o produto da multiplicação será sempre o mesmo.

Em seguida, é introduzido o algoritmo usual da multiplicação. Os procedimentos demandados por essa estratégia são explicitados passo a passo. O material de apoio ao professor reforça a necessidade de que a linguagem e registro adotados em sala de aula, assim como feito no livro, destaquem o valor posicional dos algarismos de forma a evitar erros conceituais. As quatro atividades fornecidas pelo livro para trabalhar com este conteúdo pretendem promover não só o exercício da nova estratégia, mas também relacioná-la com outros procedimentos possíveis: cálculo mental, multiplicação por decomposição e por estimativa. O tópico seguinte, Mais multiplicação, dá continuidade a este esforço com mais três atividades e introduz os cálculos com reagrupamento.

A seção Atividades fornece quatro exercícios para revisão. A sugestão é que os alunos sejam orientados a variar as estratégias de cálculo empregadas para respondê-los. Os problemas exploram a leitura e interpretação de gráfico para coleta dos dados e também o uso da calculadora em situações que motivam a multiplicação por decomposição.

A partir daí o material se dedica à divisão, retomando a multiplicação na seção Problemas, quando são oferecidas cinco atividades para a revisão do conteúdo da unidade, e também em Compreender informações, que se dedica à construção de árvores de possibilidades, argumentando que enquanto a 
multiplicação, em situações de combinação, permite conhecer "quantas possibilidades", a árvore evidencia "quais possibilidades".

\subsection{A Avaliação Nacional da Alfabetização}

O PNAIC (BRASIL, 2013a) é um compromisso assumido pelos governos federal, estaduais, municipais e do Distrito Federal, de alfabetizar as crianças até, no máximo, os 8 anos de idade, ao final do 3ํano do Ensino Fundamental (BRASIL, 2013a). Para isso, previu em sua instituição, dentre outras medidas, uma "avaliação externa universal do nível de alfabetização ao final do $3^{\circ}$ ano do ensino fundamental, aplicada pelo Inep" (BRASIL, 2013a, p. 23).

Essa previsão converteu-se na ANA, avaliação censitária de realização anual que utiliza questionários e testes de desempenho para aferir o nível de alfabetização e letramento em Língua Portuguesa e alfabetização em Matemática das crianças e as condições das instituições de ensino às quais estão vinculadas ao final do Ciclo de Alfabetização (BRASIL, 2013b).

A ANA teve sua primeira edição em 2013 e em 2016 chegou à terceira edição, já que em 2015 não houve aplicação. Para subsidiar essas aplicações, houve pré-teste de itens em duas ocasiões.

Neste ponto são pertinentes alguns esclarecimentos a respeito das condições de montagem dos testes da ANA - comuns, em sua maioria, às demais avaliações conduzidas pelo Inep. Os itens elaborados para compor a ANA, para estarem aptos para utilização, precisam passar por pré-teste. Nessa ocasião, uma amostra nacional de crianças com características semelhantes ao público-alvo final responde esses itens de forma a subsidiar a posterior análise estatística e pedagógica dos resultados (BRASIL, 2012c). O pré-teste permite identificar se os itens atendem, de fato, a habilidade à qual se destinam, se são fáceis ou difíceis e se estão adequadamente escritos e ilustrados, por exemplo (BRASIL, 2012c). Aqueles que atendem aos critérios de qualidade previamente estabelecidos passam, então, a compor o Banco Nacional de Itens - BNI.

A elaboração das matrizes de referência da ANA - que descrevem as habilidades a serem avaliadas - reuniu pesquisadores e especialistas das 
áreas do conhecimento envolvidas e representantes de diversas instituições do governo e da sociedade civil e teve como base diferentes documentos oficiais, com destaque para os Elementos Conceituais e Metodológicos para Definição dos Direitos de Aprendizagem - que, neste texto, será referenciado apenas como Direitos de Aprendizagem a partir daqui - e documentos de formação do PNAIC, além das matrizes da Provinha Brasil (INEP, 2013b). Constam ainda nas referências bibliográficas do documento básico da ANA as Diretrizes Curriculares para o Ensino Fundamental de 9 anos e documentos referentes ao Pró-Letramento.

A matriz de Matemática reúne 18 habilidades distribuídas em quatro eixos: Numérico e Algébrico, com 10 habilidades; Geometria, com 2 habilidades; Grandezas e Medidas, com 4 habilidades e Tratamento da Informação, também com 2 habilidades.

Das 10 habilidades do eixo Numérico e Algébrico, duas referem-se ao campo conceitual multiplicativo. São elas: H9 - Resolver problemas que envolvam as ideias da multiplicação e $\mathrm{H} 10$ - Resolver problemas que envolvam as ideias da divisão.

Em relação à $H 9$, as especificações da habilidade orientam a exploração de situações que envolvam adição de parcelas iguais; objetos organizados em disposição retangular; ideia de proporcionalidade (dobro, triplo etc.) e ideia de combinação.

No que diz respeito à habilidade $\mathrm{H} 10$, estão contempladas situações de repartir uma coleção de objetos em partes iguais; quantas vezes uma quantidade cabe em outra e situações envolvendo a ideia de proporcionalidade (metade, terça e quarta parte). Recomenda-se ainda considerar situações contínuas e discretas.

Com a autorização do Inep, responsável pela ANA, a pesquisadora teve acesso aos itens referentes à $\mathrm{H} 9$ - Resolver problemas que envolvam as ideias da multiplicação disponíveis no BNI. No total, foram vinte e três os itens desta habilidade que possuíam as informações estatísticas necessárias para compor o BNI, tendo passado, portanto, por ao menos um pré-teste. Parte deles, além 
de pré-testados, já foram também utilizados nas provas montadas até o momento. Como os itens, por vezes, são pré-testados e testados mais de uma vez, apresentando, assim, dados estatísticos de várias aplicações, optou-se por tomar como base para a descrição e análise, os dados provenientes da primeira pré-testagem do item.

Para determinar qual ideia da multiplicação é contemplada pelo item, observou-se o registro do próprio elaborador no campo das palavras-chave. Apenas quatro itens não continham essa indicação e foram, então, classificados pela pesquisadora de acordo com suas características.

Para respeitar o sigilo dos itens, a pesquisadora elaborou itens nos moldes dos que compõem o BNI para representar cada uma das categorias de situações indicadas nas especificações da habilidade H9, quais sejam: adição de parcelas iguais; disposição retangular; proporcionalidade e combinação.

Ordenando o conjunto de itens de forma crescente pela porcentagem de acerto $^{2}$ de cada um deles, é nítida a formação de dois grupos independentes: um deles é composto pelas situações de combinação e o outro pelas ideias de adição de parcelas iguais e proporcionalidade. Enquanto neste último grupo os itens chegam a apresentar $63 \%$ de acerto e o menor índice registrado é de $31,3 \%$ de acerto, o item de combinação mais fácil foi acertado por $20,6 \%$ dos estudantes e o mais difícil por apenas $8,4 \%$.

A ideia denominada adição de parcelas iguais foi representada por itens como o que se segue:

Estela usa seis botões em cada um dos vestidos que faz. De quantos botões ela precisará para fazer 8 vestidos?
A) 6
B) 8

2 Seria possível, também, ordenar os itens pelo B-escala, mas considerou-se que a porcentagem de acerto é um dado mais palpável para o público desta pesquisa. O B-escala refere-se a um dos três parâmetros considerados pela Teoria de Resposta ao Item (TRI), utilizada para a análise dos resultados das avaliações desenvolvidas pelo Inep. Enquanto o B diz respeito à dificuldade do item, o $\mathrm{A}$ refere-se à discriminação e o $\mathrm{C}$ à probabilidade de acerto ao acaso (BRASIL, 2012c). 
C) 14

D) 48

Esta categoria foi contemplada com 9 itens, dos quais 3 ofereceram aos alunos o suporte de imagens representando o multiplicando. Apenas 2 itens envolveram números maiores que 10. Os estudantes foram atraídos por alternativas que apresentavam como resposta um dos números dados no enunciado ou a soma desses valores, mas, no geral, obtiveram bons resultados diante de situações deste tipo: a porcentagem de acerto variou entre $32 \% \mathrm{e}$ $63 \%$.

Apenas 2 itens exploraram situações de objetos organizados em disposição retangular. Ambos ofereceram suporte de imagem aos estudantes: em um deles foram representados os elementos de uma linha e uma coluna enquanto no outro uma figura cobria parcialmente os elementos internos. $O$ cálculo demandado foi o mesmo, envolvendo números menores que seis, mas os resultados foram bastante divergentes: enquanto o primeiro obteve apenas $14,1 \%$ de acerto, o segundo foi acertado por $50,4 \%$ das crianças. O erro mais cometido por elas consistiu na simples contagem dos elementos ilustrados. Esses itens se assemelham ao modelo a seguir:

Júlio precisa cobrir essa parede inteira com azulejos. Veja o que ele já fez:

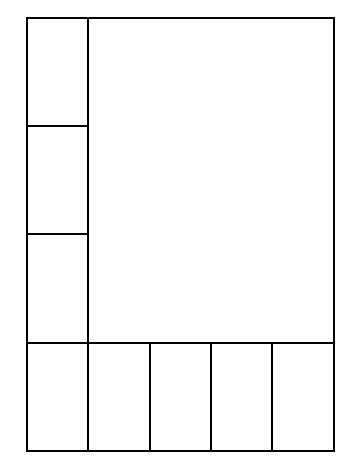

No total, quantos azulejos Júlio usará para essa tarefa?
A) 8
B) 9 
C) 20

D) 45

A categoria proporcionalidade foi representada por situações de dobro, triplo e "quatro vezes mais", em itens semelhantes ao exemplo a seguir:

Marina tem 4 bonecas e sua prima Larissa tem o dobro dessa quantidade. Quantas bonecas Larissa tem?
A) 2
B) 4
C) 6
D) 8

O BNI conta com 5 itens desse tipo e apenas 1 deles possui imagem. Um único item envolve um número maior que dez. A porcentagem de acerto foi considerável: o item mais difícil obteve $31,3 \%$ de acerto enquanto o mais fácil chegou a $59,2 \%$. Aqui, as alternativas atrativas foram mais diversificadas: a quantidade de elementos representados na imagem, o número explícito no enunciado, a troca de triplo por dobro e a soma dos dados do enunciado (associando 2 a dobro e 3 a triplo).

A combinação foi explorada por 7 itens que se aproximam deste:

Andressa joga num time de futebol que possui 3 modelos diferentes de camiseta e 2 modelos de bermuda. De quantas formas diferentes o time pode montar o uniforme?
A) 2
B) 3
C) 5
D) 6

Em quatro deles, todos os elementos envolvidos foram ilustrados. É notável que o contexto dessas situações ficou restrito à combinação de peças de vestuário: a diversificação ficou por conta de apenas 1 item, que ofereceu como contexto a preparação de pizzas. Nenhum dos cálculos requisitados continham números maiores do que seis e quatro itens solicitaram o mesmo 
cálculo. Nessa categoria, os estudantes foram atraídos pelas alternativas que ofereceram como resposta a repetição de um dos valores dados no enunciado ou ainda a soma desses valores.

\subsection{O Ponto de Vista das Professoras}

As duas professoras participantes da pesquisa, P1 e P2, foram entrevistadas em meados de setembro de 2016, período escolhido com o intuito de aumentar a probabilidade de que a multiplicação já estivesse sendo trabalhada nas turmas de $3^{\circ}$ ano do Ensino Fundamental.

Ambas as participantes informaram ensinar multiplicação no ano escolar em questão por reconhecerem que esse conteúdo "faz parte do currículo" (P1) ou "sempre fez parte do conteúdo programático" (P2). P1 ainda acrescenta às justificativas o fato de que a multiplicação "faz parte da vida do aluno".

Segundo elas, esse trabalho é iniciado no segundo bimestre escolar, por decisão do grupo de professoras: "nós temos conteúdo programático pro ano todo e nós, no começo do ano, fazemos o planejamento dividindo mais ou menos durante os bimestres" (P2). De acordo com P1, esse período é conveniente porque confere aos docentes um maior período de tempo para o desenvolvimento desse tópico: "a gente discute e acha melhor que a gente tem todo o ano pra trabalhar e pode ir aprofundando". P2 alerta que essa decisão, no entanto, "não é uma coisa fechada [...] tem ano que a gente adianta, tem ano que acaba atrasando, depende se a turma tá dando conta" e informa que "esse ano, inclusive, nós já introduzimos a divisão porque eles estão pegando bem".

Sobre os conhecimentos prévios dos estudantes, ambas afirmam que as crianças chegam ao 3ำ ano do Ensino Fundamental já com algumas noções a respeito da multiplicação. P1 exemplifica: "a multiplicação por dois, por três, números menores eles já conheciam", mas, de acordo com P2 "armar mesmo e aprender e até a parte de memorização é agora no terceiro". 
Quando questionadas sobre as estratégias e recursos que utilizam para introduzir a multiplicação em suas aulas, as professoras deram ênfase aos desenhos e materiais concretos, citando balas, palitos e tampinhas. Segundo elas, iniciar desse modo auxilia os alunos a compreender as situações apresentadas:

"No começo também, além de usar o material concreto, eles desenham. Antes de eu partir pra cobrar a memorização, eles desenham a multiplicação, eles entendem que duas vezes 0 três, por exemplo, é diferente de três vezes o dois, apesar de ter o mesmo resultado" (P1).

"Eu vejo que tem criança que sabe assim de cor, mas não entende como funciona, então a gente faz muita questão que eles desenhem pra ver se eles realmente compreenderam que, por exemplo, duas vezes o três é fazer o três e depois o três novamente, que é adição de parcelas iguais. Eles têm que ter essa compreensão, tanto na multiplicação quanto na divisão, então uso muito material concreto e desenho, ilustração, bastante, até eles compreenderem mesmo, porque, a partir do momento que ele compreender, ele faz multiplicação por três por quatro por cinco por nove, né" (P2).

Sobre as fontes de materiais às quais recorrem, o coletivo de professores recebe destaque. P1 declara buscar os materiais fornecidos pela SEEDF nos cursos de formação continuada e livros, além de "trocar ideias na coordenação". Já P2 revela que, para ela, essa partilha entre professores se dá também pela internet:

"Eu tenho vários jogos [...] tem muita atividade de livro, de coleções, né? $E$ na internet tem coisa legal que os outros professores compartilham, aí eu gosto de olhar também".

O livro didático, segundo elas, está presente nas aulas, mas não é utilizado logo na introdução do conteúdo de multiplicação. Para P2 "o livro vem de uma forma mais complicadinha pra eles, então eu deixo pra trabalhar o livro só depois que eu já trabalhei bastante a parte bem concreta". De forma semelhante, P1 afirma:

"No primeiro momento eu prefiro o material concreto, ele desenha no caderno. Quando eu vejo que eles já entenderam o processo, que estão mais seguros, aí sim eu parto pro livro." 
O exemplar utilizado por elas foi escolhido coletivamente pelos professores da escola. As professoras contam que receberam vários exemplares para análise e que foram orientadas a escolher uma das coleções, que seria então adotada por todas as turmas. Para isso foi necessário chegar a um consenso, como descreve P2:

"Junta todos os professores e a gente tenta convencer um ao outro "oh, pra mim, pro terceiro ano isso não é bom". Aí a outra do primeiro ano "ah, mas pra mim isso aqui é bom". Mas aí nós fazemos um acordo, esse ano deu tudo certo" (P2).

Um outro desafio que se apresenta nesse momento, segundo $\mathrm{P} 1$, é o curto espaço de tempo destinado à tarefa:

"O tempo que a gente tem pra escolha é muito pequeno né, foi assim, dois dias! Esse ano, a gente optou pelo que a gente já conhecia por causa do tempo. A gente não tinha muito tempo pra olhar, então como o livro que a gente usou no ano passado foi muito bom, a gente optou por continuar com ele né, quer dizer, a oferta é muito grande, mas a gente não tem tempo pra olhar" (P1).

A respeito das avaliações externas que se destinam ao ciclo de alfabetização - ANA e Provinha Brasil - ambas as professoras afirmaram conhecê-las e julgam que a forma como a multiplicação está presente nelas é adequada aos conhecimentos adquiridos pelos alunos nesse período. P2 ainda aponta que procura levar para a sala de aula situações que se aproximem daquelas apresentadas nos testes:

"Nós gostamos sempre de fazer questões também bem parecidas, né. Por exemplo, se tem uma do outro ano eu pego e faço porque ela envolve mais raciocínio, né? Não envolve muito a multiplicação mesmo em si, a operação."

Ao questionamento "você gosta de ensinar multiplicação?", as professoras responderam, de forma similar, que gostam de perceber que os alunos estão aprendendo: 
"Eu acho bom quando ele entende, né? Então eu faço muita questão disso, deles compreenderem. Tem menino que acho que a mãe ensina em casa, né? "Ah, minha mãe já me ensinou". Aí sabe tudo de cor, mas não entendeu o processo da multiplicação" (P2).

"Fico feliz quando eu vejo eles descobrindo, sabe? Resolvendo situações-problema, aplicando, né? Quando eu dou um problema, ele pode resolver com a adição, mas quando eu vejo que o menino já tá usando a multiplicação, isso aí me deixa muito feliz, eu vejo que ele entendeu" (P1).

P1 e P2 também convergem ao afirmar que seus alunos - no terceiro bimestre do ano letivo, quando se deu a entrevista - já sabiam multiplicar e não tiveram dificuldades para alcançar esse objetivo. Para P1, nessa fase da escolarização,

"A maior dificuldade mesmo é em português, é escrever, mas matemática não, eles gostam."

Sobre o desempenho dos alunos em problemas e continhas, as professoras concordam que os problemas representam maior dificuldade para eles. Para P1, isso acontece

"Porque aí vai entrar a questão da leitura, da interpretação do que ele está lendo, então resolver continhas é mais fácil."

P2 também relata que

“Tem aluno que já diz 'ah não, tem que ler!', o problema maior deles é a leitura, compreender isso, sabe? Mas assim, oitenta por cento da turma é muito, assim, rápido no raciocínio, então faz de boa qualquer coisa."

Neste ponto da entrevista as professoras receberam 20 fichas com situações-problema. As fichas contemplavam as quatro ideias da multiplicação descritas nos PCN com 5 situações para cada uma dessas ideias. As categorias foram representadas por problemas com e sem suporte de imagem para a resolução. 
Num primeiro momento, as participantes foram orientadas a apontar as oito situações-problema, dentre as apresentadas, que elas prioritariamente usariam em sala de aula ao trabalhar a multiplicação com seus alunos.

A seleção de $\mathrm{P} 2$ apresenta as seguintes fichas:

Maria ganhou 3 cadernos e, para enfeitá-los, colou 5 adesivos em cada.

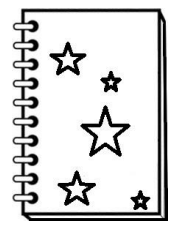

Quantos adesivos Maria usou para enfeitar os 3 cadernos?

(proporcionalidade)

Para fazer um bolo, a receita de Luísa leva 4 ovos. Luísa quer fazer 2 bolos usando essa receita. Quantos ovos ela vai usar?

(proporcionalidade)

Antônio plantou 2 fileiras com 5 árvores em cada uma. Quantas árvores Antônio plantou no total?

(configuração retangular)

A professora de Dora organizou todos os alunos da turma em 6 grupos com 4 alunos em cada um.

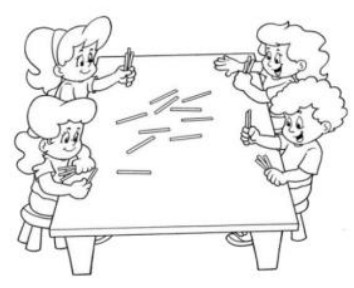

Quantos alunos havia na turma de Dora?

(proporcionalidade) 
Gabriela e seu amigo estavam brincando com o jogo da memória e organizaram as cartas em linhas e colunas. Veja:

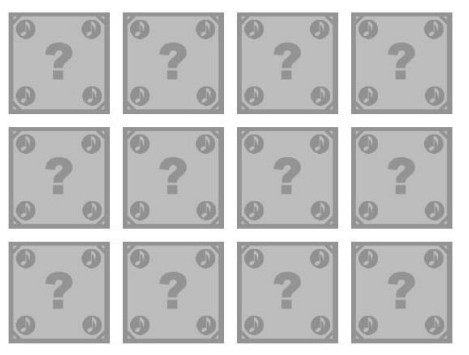

Quantas cartas o jogo tem ao todo?

(configuração retangular)

Quantos conjuntos diferentes de uma calça e uma camisa podem ser formados com 3 calças distintas e 4 camisas diferentes entre si?
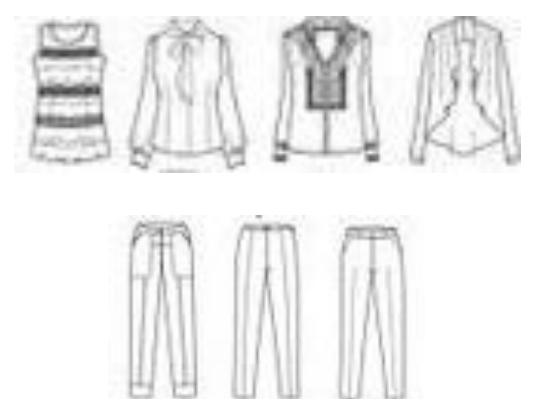

(combinatória)

Um prédio tem 5 andares. Em cada andar há 4 apartamentos. Quantos apartamentos há no prédio?

(configuração retangular)

Larissa tem 6 anos. O pai de Larissa é 5 vezes mais velho do que ela. Quantos anos ele tem?

(multiplicação comparativa) 
Enquanto analisava as fichas, P2 declarou sua preferência pelas situações-problema que oferecem ilustrações como apoio para os estudantes e também manifestou sua preocupação de contemplar a variedade de ideias que se relacionam com a multiplicação, o que pode ser percebido no trecho a seguir:

"Combinação, né? Isso aqui é importante, a gente trabalha muito, o livro pede muito isso e, nos cursos que nós fizemos [foi abordada a importância de] trabalhar a multiplicação não só da mesma forma, né? Adição de parcelas iguais, a combinação, outras formas [...] são todos bons, tem que pegar diferente" (P2).

Já a escolha de P1 se deu da seguinte forma:

Para fazer um bolo, a receita de Luísa leva 4 ovos. Luísa quer fazer 2 bolos usando essa receita. Quantos ovos ela vai usar?

(proporcionalidade)

Antônio plantou 2 fileiras com 5 árvores em cada uma. Quantas árvores Antônio plantou no total?

(configuração retangular)

A professora de Dora organizou todos os alunos da turma em 6 grupos com 4 alunos em cada um.

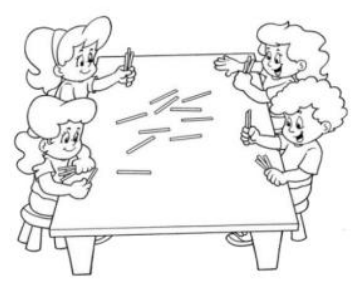

Quantos alunos havia na turma de Dora?

(proporcionalidade) 
Maria ganhou 3 cadernos e, para enfeitá-los, colou 5 adesivos em cada.

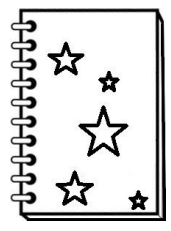

Quantos adesivos Maria usou para enfeitar os 3 cadernos?

(proporcionalidade)

Em uma sorveteria, o sorvete pode ser servido em casquinha ou copinho. São 4 sabores diferentes: menta, baunilha, chocolate e morango. Maria quer uma bola de sorvete. Quantas combinações diferentes ela tem para escolher?

(combinatória)

Num auditório, as cadeiras estão dispostas em 7 fileiras e 8 colunas.

Quantas cadeiras há no auditório?

(configuração retangular)

Para enfeitar o pátio da escola, os colegas de Lucas fizeram 4 cordões com 120 bandeirinhas em cada um. Quantas bandeirinhas foram feitas?

(proporcionalidade)

Veja os doces que Carina fez para a festa da escola.
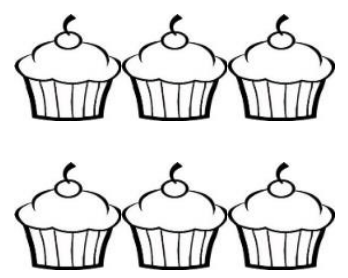

Sara fez o dobro dessa quantidade de doces. Quantos doces Sara fez?

(multiplicação comparativa) 
Para P1, o apoio de imagem também foi critério para a seleção das fichas:

"Eu gosto quando eu percebo que o aluno vai ter mais facilidade pra desenhar o que ele leu [...] então aqui quando tem "duas fileiras, em cada fileira tem cinco árvores" eu mandaria eles desenharem [então eu selecionei aqueles] ou que já tem o desenho ou que eu acho que vai ser mais fácil pra ele desenhar pra facilitar o entendimento dele" (P1).

Ao serem questionadas sobre as situações, dentre as 20 apresentadas, nas quais elas acreditavam que seus alunos alcançariam maior sucesso ao resolver, P2 apontou a seguinte ficha, que considerou "a mais simples":

Maria ganhou 3 cadernos e, para enfeitá-los, colou 5 adesivos em cada.

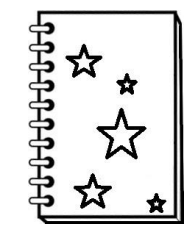

Quantos adesivos Maria usou para enfeitar os 3 cadernos?

(proporcionalidade)

P1 indicou a situação a seguir, justificando que os alunos poderiam desenhar para facilitar a resolução:

Antônio plantou 2 fileiras com 5 árvores em cada uma. Quantas árvores Antônio plantou no total?

(configuração retangular)

Já sobre a ficha que representaria maior dificuldade para suas turmas, P1 e P2 convergiram na escolha:

Em uma barraquinha que servia sanduíche, era possível pedir com recheio de salsicha ou linguiça, com molho ou sem molho. De quantas maneiras era possível pedir um sanduíche?

(combinatória) 
Para P2, esse tipo de situação "envolve mais um pouquinho de raciocínio [...] inclusive tem no nosso livro problemas parecidos e eles têm muita dificuldade". De forma complementar, P1 declara:

"Eu vejo que eles têm dificuldade de abstrair, então ele vai ter que imaginar aqui, que fala de barraquinha, quantas maneiras ele pode servir o sanduíche. Essa capacidade de criar, de imaginar o que vem depois, eles têm muita dificuldade [...] tá muito longe, a abstração é difícil” (P1).

O capítulo seguinte se dedicará à análise dos resultados aqui apresentados. 


\section{CAPÍTULO 5}

\section{ANÁLISE E DISCUSSÃO DOS RESULTADOS}

Os resultados descritos no capítulo anterior foram analisados conjuntamente a partir de cinco categorias: uma para cada ideia da multiplicação aqui discutida e outra que agrupa reflexões sobre os aspectos didáticos que permearam os materiais analisados.

\subsection{Multiplicação Comparativa}

A multiplicação comparativa corresponde a situações em que duas grandezas do mesmo tipo são comparadas por meio de uma razão entre elas (GITIRANA et al., 2014), como no exemplo a seguir: "Marta tem 4 selos e João tem 5 vezes mais selos que ela. Quantos selos tem João?" (BRASIL, 1997, p. 109). Como já posto anteriormente, as expressões " $x$ vezes mais" e " $x$ vezes menos" (VERGNAUD, 2009) e ainda os conceitos de dobro, triplo, quádruplo e etc. são característicos dessa classe, uma vez que destacam a razão - ou operador-escalar (VERGNAUD, 2009) - que estabelece a comparação.

A análise dos documentos tomados enquanto representantes de diversos níveis curriculares revelou ausências significativas no que diz respeito a essa classe de situações. No livro didático, essa ideia é introduzida quando são apresentados os numerais multiplicativos (dobro, triplo, quádruplo e quíntuplo), mas não são exploradas situações de multiplicação comparativa para além dessas.

O Currículo em Movimento não contempla essa classe de problemas e não faz menção, sequer, às ideias de dobro, triplo etc. Na tabela que apresenta os conteúdos para $03^{0}$ ano do Ensino Fundamental há referência à proporcionalidade como uma das ações da multiplicação, mas essa ideia não é formalmente introduzida e nem são fornecidos exemplos de situações desse tipo que permitam caracterizá-la e, portanto, não cabe aproximá-la do que é entendido como multiplicação comparativa. 
A matriz da ANA denomina a multiplicação comparativa como "proporcionalidade" e, de forma similar ao livro didático, faz referência a ela de forma restrita, citando apenas aquelas situações que envolvem as nomenclaturas dobro, triplo etc. Os itens elaborados a partir dela, no entanto, não se limitaram a essa abordagem: consta no BNI um item que demanda o cálculo de "quatro vezes" uma determinada quantidade de chocolate.

A ausência de referência explícita a esse conceito da multiplicação se repete em documentos curriculares de abrangência nacional ${ }^{3}$. Os Direitos de Aprendizagem (BRASIL, 2012a), no que diz respeito à multiplicação comparativa, evidenciam apenas os numerais multiplicativos. O mesmo ocorre na prescrição prevista na segunda versão da Base Nacional Curricular Comum - BNCC (BRASIL, 2016a) para os três primeiros anos do ensino fundamental. A matriz da Provinha Brasil (BRASIL, 2016b) e os documentos das formações promovidas pelo Pró-Letramento (BRASIL, 2008a) e pelo PNAIC (BRASIL, 2014), também não trazem esses conceitos.

A carência de informações a respeito dessa classe de problemas nos materiais curriculares parece se refletir nas escolhas das professoras: durante as entrevistas, as duas professoras participantes incluíram apenas uma situação de multiplicação comparativa nas suas seleções, compostas por oito fichas no total.

P2 optou por uma situação que traz a expressão "x vezes mais":

Larissa tem 6 anos. O pai de Larissa é 5 vezes mais velho do que ela. Quantos anos ele tem?

Já a ficha escolhida por P1 aborda uma outra faceta desta categoria, o uso do termo "dobro":

\footnotetext{
${ }^{3}$ A opção por referenciar estes documentos e não outros se baseia no fato de que estes foram explicitamente declarados como embasamento para as propostas do livro didático e da matriz da ANA. Considerou-se também que ambas as professoras participaram das formações do PNAIC. Já a BNCC é anunciada como fruto das orientações nacionais, estaduais e municipais já existentes.
} 
Veja os doces que Carina fez para a festa da escola.

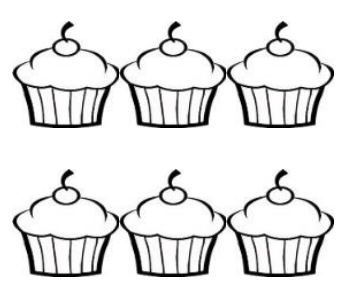

Sara fez o dobro dessa quantidade de doces. Quantos doces Sara fez?

Apesar do cenário marcado pela sub-representação da multiplicação comparativa nas diferentes instâncias do currículo aqui analisadas, os itens que envolviam este tipo de raciocínio disponíveis no BNI compuseram, junto àqueles de "adição de parcelas iguais", o conjunto no qual os alunos do $3^{\circ}$ ano do ensino fundamental obtiveram maior porcentagem de acerto (entre 31,3\% e $59,2 \%)$.

De acordo com Vergnaud (2009), a multiplicação comparativa (por ele denominada "caso de um único espaço de medidas") é facilmente compreendida pelas crianças, embora demande um certo aprofundamento no que diz respeito à distinção entre medida e escalar. Isso porque, diferente do que ocorre nos problemas de proporcionalidade - que corresponde ao "isomorfismo de medidas" na classificação de Vergnaud (2009) -, o operadorescalar é que está em evidência, estabelecendo a relação entre duas medidas da mesma categoria.

Complementarmente, Gitirana et al. (2014) aponta que o baixo nível de dificuldade que esse tipo de situação apresenta aos estudantes desde o início do estudo da multiplicação se deve à sua proximidade com o campo aditivo: "assim como na adição, o estudante ainda está diante de uma operação ternária, que envolve três números ou grandezas" (GITIRANA et al., 2014, p.45). Nesse caso, as grandezas envolvidas são as duas medidas e a razão estabelecida entre elas.

É interessante notar ainda que uma porcentagem considerável de respondentes dos testes da ANA (algo entre 20\% e 30\% em cada um dos três itens que apresentaram essa possibilidade) foi atraída pelas alternativas que apresentavam como resposta a soma do número explícito no enunciado à 
razão apresentada, mesmo quando esta foi introduzida pelos termos "dobro" ou "triplo" - que os estudantes associaram a "dois" e "três", respectivamente.

Essa conversão de "dobro" para "dois" e de "triplo" para "três" demonstra que os alunos possuem algum conhecimento a respeito da multiplicação comparativa, mas o procedimento de somar os dados do problema sugere que o pensamento aditivo ainda se sobrepõe ao multiplicativo. De acordo com Monteiro (2008), essa estratégia é muito comum, uma vez que os alunos, nessa etapa da escolarização, estão habituados a problemas do campo aditivo nos quais ela, de fato, se mostra válida.

\subsection{Proporcionalidade}

A ideia de proporcionalidade está presente em situações que estabelecem uma relação (quaternária) entre quatro quantidades, duas a duas de mesmo tipo (VERGNAUD, 2009). Os problemas deste tipo são semelhantes a: "Marta vai comprar 3 pacotes de chocolate. Cada pacote custa $\mathrm{R} \$ 8,00$. Quanto ela vai pagar pelos 3 pacotes?".

\subsubsection{Adição de parcelas iguais?}

Chama a atenção o fato de que todos os documentos analisados para os fins desta pesquisa se refiram a essa classe de situações multiplicativas como "adição de parcelas iguais" - ou as variantes "repetição", "soma" e "agrupar" parcelas iguais, introduzidas pelo Currículo em Movimento (GDF, 2013).

A associação da proporcionalidade, como aqui definida, ao campo aditivo foi observada, ainda, em outros documentos curriculares, como a matriz da Provinha Brasil (BRASIL, 2016b) e os materiais do Pró-Letramento (BRASIL, 2008a). A BNCC (BRASIL, 2016), até a segunda versão apresentada, incorpora essa tendência em sua proposta.

Essa opção teórica, insistentemente reforçada nos documentos orientadores da educação no Brasil, perpassa as experiências formativas dos 
professores e, naturalmente, passa a compor seus conhecimentos profissionais, influenciando suas práticas. Durante as entrevistas, foi possível notar que a associação desta faceta da multiplicação ao raciocínio aditivo, incluindo a nomenclatura "adição de parcelas iguais", está presente no discurso das professoras participantes, como evidenciado nos trechos a seguir:

"A gente faz muita questão que eles desenhem pra ver se eles
realmente compreenderam que, por exemplo, duas vezes o
três é fazer o três e depois o três novamente, que é adição de
parcelas iguais" (P2).
"Quando eu dou um problema, ele pode resolver com a adiçãa,
mas quando eu vejo que o menino já tá usando a multiplicação,
isso aí me deixa muito feliz, eu vejo que ele entendeu" (P1).

O livro didático, ao introduzir a ideia de proporcionalidade, solicita que os alunos representem as situações-problema primeiro por uma adição e só então pela multiplicação correspondente. O material de apoio ao professor justifica essa abordagem com a afirmação de que a escrita aditiva "facilita a obtenção dos resultados e a verificação da compreensão do significado de cada multiplicação" (MODERNA, 2014, p. 403).

Essa compreensão é referendada em outros âmbitos: os materiais relativos ao Programa Gestão da Aprendizagem Escolar (Gestar), iniciativa de formação continuada de professores promovida pelo Ministério da Educação MEC, apontam que, diante da ideia de proporcionalidade, a escrita multiplicativa consiste em "um modo mais econômico" (BRASIL, 2007, p. 37) para representar uma adição de parcelas iguais. No mesmo sentido, de acordo com a matriz da Provinha Brasil "a partir dessa ideia, a escrita $3 \times 4$ aparece como uma forma reduzida da escrita aditiva $4+4+4$ " (2016b, p.18).

Esse modo de conceituar a multiplicação, no entanto, é alvo de inúmeras contestações que alertam para a necessidade de evidenciar as descontinuidades entre as situações do campo aditivo e aquelas do campo multiplicativo. Nunes et al. (2009) contribuem para essa discussão apontando que a relação entre a multiplicação e a adição "está centrada no processo de cálculo da multiplicação: o cálculo da multiplicação pode ser feito usando-se a 
adição repetida porque a multiplicação é distributiva com relação à adição" (p.84).

Para além dessa ligação, o que existem são consideráveis rupturas conceituais. Uma primeira diferenciação que pode ser apontada é que o raciocínio aditivo está baseado na relação parte-todo (o todo é igual à soma das partes), enquanto o multiplicativo se apoia na existência de uma relação fixa entre variáveis (NUNES et al. 2009). Nessa perspectiva, Nunes et al. (2009) indicam que um problema, para ser definido como de adição repetida, teria a seguinte configuração: "Antônio tem 3 carrinhos e Ana tem 3 bonecas. Quantos brinquedos eles têm ao todo?" (p.103). Nesse caso, dois conjuntos de brinquedo formam um todo. Já um problema de correspondência um-a-muitos (aqui denominado proporção) poderia ser exemplificado assim: "A mãe de Ana está fazendo 2 panelas de sopa. Em cada panela ela vai usar 3 tomates. Quantos tomates ela vai usar ao todo?" (p.104). Essa situação, diferente da primeira, apoia-se na correspondência entre o número de panelas de sopa e o número de tomates.

Gitirana et al. (2014) apresentam ainda outra consideração importante a respeito das ampliações trazidas pelo raciocínio multiplicativo em relação ao aditivo. Os problemas desta última classe envolvem três grandezas de mesma espécie numa relação ternária (somam-se brinquedos com brinquedos e obtêm-se brinquedos), enquanto a multiplicação com ideia de proporcionalidade introduz uma relação entre quatro grandezas (duas de cada tipo), configurando uma relação quaternária (GITIRANA et al., 2014).

O livro didático analisado pleiteia a favor da aproximação da multiplicação à ideia de adição repetida considerando que essa estratégia define papeis diferentes para o multiplicador (o número que indica quantas são as repetições) e para o multiplicando (o número que se repete), permitindo esclarecer que não é possível tomar um pelo outro (MODERNA, 2014). Essa é uma preocupação presente também no discurso de P1:

"Antes de eu partir pra cobrar a memorização, eles desenham a multiplicação, eles entendem que duas vezes o três, por exemplo, é diferente de três vezes o dois, apesar de ter 0 mesmo resultado." 
Os PCN (BRASIL, 1997), no entanto, ponderam que, embora a abordagem de estabelecer uma relação entre multiplicação e adição possa ser relevante como um ponto de partida, na medida em que permite diferenciar 0 multiplicador e o multiplicando, ela não é suficiente para habilitar o aluno a lidar com o campo multiplicativo. Como exemplo dessa insuficiência, Vergnaud (2009a) observa que, por mais que a associação da multiplicação à adição possa ser facilmente aceita como satisfatória enquanto os alunos lidam com grandezas discretas e números inteiros, ela demandará

Explicações suplementares para fazer a criança compreender que o preço de 3,50 metros é o preço de um metro, mais o preço de um metro, mais o preço de um metro, mais o preço de 0,50 metros; e que isso é o mesmo que multiplicar o preço de um metro por 3,50 (VERGNAUD, 2009a, p.241).

Resolver problemas de proporcionalidade por adição repetida também não municia o aluno para operar situações mais complexas desta categoria, nas quais o valor unitário não é conhecido. Essas situações, no livro didático analisado, são diferenciadas daquelas por ele definidas como "adição de parcelas iguais". São os problemas do tipo "Se 2 canetas custam, juntas, 3 reais, qual é o preço de 4 dessas canetas?" (MODERNA, 2014) que o livro denomina como sendo de "proporcionalidade".

$\mathrm{Na}$ classificação proposta por Gitirana et al. (2014) essas situações, assim como as que evidenciam o valor unitário, são classificadas como "proporção simples", mas as autoras as localizam numa subcategoria, a "quarta proporcional". É interessante notar que, segundo elas, os alunos teriam competência para resolver problemas deste tipo a partir do $4^{\circ}$ ano do ensino fundamental (GITIRANA et al., 2014).

Para Vergnaud (2009a), a diferença entre uma situação e outra está na complexidade - segundo ele, nas situações mais simples, sabe-se que uma das quatro quantidades relacionadas é igual a um - mas ambas compõem a classe "isomorfismo de medidas". Os PCN também não diferenciam as ideias inerentes a esses dois casos. 
Diante desses argumentos, parece razoável reconhecer que o ensino da multiplicação com continuidade da adição pode trazer dificuldades aos alunos na medida em que as rupturas necessárias entre as duas operações não puderem mais ser ignoradas (GITIRANA et al., 2014).

Nesse ponto cabe refletir sobre o que os itens de proporcionalidade disponíveis no BNI podem revelar. Ao resolvê-los, os estudantes que erraram optaram, majoritariamente, pelas alternativas que apresentavam como resposta um dos números dados no enunciado ou ainda a soma desses valores. É reconhecido que, muitos alunos, no início da aprendizagem, consideram plausível tentar resolver os problemas de multiplicação apenas somando os valores presentes no enunciado, sem se dar conta de que estes referem-se a elementos de naturezas diferentes (BRASIL, 2007). Dentre outros fatores que podem influir nesse comportamento, como a dificuldade de leitura ou interpretação do texto em si, talvez esteja a pouca atenção que as diferenças entre campo aditivo e multiplicativo têm recebido em sala de aula, com o aval dos documentos curriculares que orientam a prática pedagógica.

\subsubsection{Proporcionalidade e reducionismo conceitual}

É sabido que, por vezes, a escola acaba enfatizando a ideia de proporcionalidade no ensino da multiplicação (MUNIZ, 2009; MORETTI e SOUZA, 2015). Muniz (2009) relaciona essa realidade ao reducionismo conceitual, que ocorre quando não se reconhece a imersão de uma determinada situação em um campo conceitual, ignorando, portanto, conexões e relações imprescindíveis para o domínio pleno de determinado conceito. Segundo o autor:

Essa postura faz com que a escola trabalhe apenas uma dimensão conceitual de cada operação e, portanto, acabe por não instrumentalizar efetivamente os alunos a dar conta da grande gama de situações que implicam os demais conceitos das operações matemáticas (MUNIZ, 2009, p. 103).

A investigação aqui descrita aponta para um movimento amplo de superação do reducionismo conceitual. Todos os documentos curriculares 
analisados abordaram a multiplicação em sua diversidade conceitual e as professoras entrevistadas demonstraram estar cientes da relevância da diversificação das situações multiplicativas em sala de aula. P1 e P2 incluíram as quatro categorias de situações de multiplicação nas seleções solicitadas durante as entrevistas e P2 manifestou sua consciência a respeito da importância dessa variedade com a seguinte colocação:

"Nos cursos que nós fizemos [foi abordada a importância de] trabalhar a multiplicação não só da mesma forma, né? Adição de parcelas iguais, a combinação, outras formas [...] são todos bons, tem que pegar diferente" (P2).

No entanto, a proporcionalidade ainda assumiu certo protagonismo. Os itens referentes a essa ideia da multiplicação foram responsáveis por cerca de $40 \%$ dos itens disponíveis no BNI para avaliar a habilidade H9 - Resolver problemas que envolvam as ideias da multiplicação. Seguindo essa mesma tendência, as professoras, ao serem orientadas a selecionar oito situações que julgassem relevantes para o seu trabalho em sala de aula, optaram por mais fichas de proporcionalidade do que de qualquer outra categoria (cada uma das quatro categorias foi representada por cinco fichas). P2 escolheu três situações de proporcionalidade e P1 compôs a metade de sua seleção (quatro fichas) com problemas deste tipo.

A análise dos itens para a ANA também indicou que são nas situações de proporcionalidade que os alunos demonstram maior domínio: a taxa de acerto ficou entre $32 \%$ e $63 \%$. A professora P2 compartilha da crença de que as crianças do $3^{\circ}$ ano do ensino fundamental têm mais facilidade com essa ideia da multiplicação. Segundo ela, a ficha a seguir seria "a mais simples" dentre as apresentadas:

Maria ganhou 3 cadernos e, para enfeitá-los, colou 5 adesivos em cada.

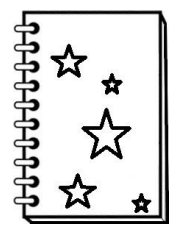

Quantos adesivos Maria usou para enfeitar os 3 cadernos? 
De fato, é reconhecido (BRASIL, 1997; BRASIL, 2007 GITIRANA et al., 2014; MORETTI e SOUZA, 2015) que a proporcionalidade é bem compreendida pelos alunos, seja por estar presente em situações frequentes no cotidiano (BRASIL, 1997), por ser o enfoque mais natural da multiplicação (BRASIL, 2007), ou ainda a mais comum e mais abordada em sala de aula (MORETTI; SOUZA, 2015).

\subsection{Configuração Retangular}

A multiplicação em contexto de configuração retangular se dá como uma relação ternária na qual uma quantidade é produto de outras duas (VERGNAUD, 2009a) e está relacionada ao o conceito de área (MUNIZ, 2009; GITIRANA et al., 2014). Como exemplo, podemos utilizar a seguinte situação: "Num pequeno auditório, as cadeiras estão dispostas em 7 fileiras e 8 colunas. Quantas cadeiras há no auditório?" (BRASIL, 1997, p.110).

Teoricamente, é recorrente a associação dessa ideia da multiplicação associada à de combinação (VERGNAUD, 2009a; MUNIZ, 2009; GITIRANA et al., 2014), entendendo que ambas são interpretações possíveis para os problemas com a estrutura descrita (uma relação ternária qual se obtém uma nova grandeza como produto de outras duas). No entanto - talvez como recurso didático, tendo em vista a natureza curricular desses materiais -, os documentos analisados para os fins desta pesquisa optaram por distinguir as situações de configuração retangular das de combinação, sem nem mesmo anunciar o vínculo entre elas.

Esse tipo de situação foi contemplado nas seleções das duas professoras participantes. P2 incluiu três fichas de configuração retangular na sua amostra de oito problemas multiplicativos. P1 escolheu duas situações desse tipo e ainda apontou uma delas como a que considera mais acessível aos alunos:

Antônio plantou 2 fileiras com 5 árvores em cada uma. Quantas árvores Antônio plantou no total? 
P1 argumentou que, nesse caso, as crianças teriam facilidade para representar o problema com desenhos de forma a auxiliar a resolução.

O discurso das professoras em conjunto com as descrições e exemplos fornecidos nos documentos curriculares destinados ao ciclo de alfabetização sugere que o que se espera dos alunos nesta faixa etária é uma compreensão ainda elementar de leitura de linha por coluna ou vice-versa. Gitirana et al. (2014) reconhecem esse entendimento da formação linha x coluna com valores naturais como uma fase preliminar que é posteriormente expandida para medidas racionais e irracionais.

As situações presentes no Currículo em Movimento (GDF, 2013a), no livro didático (MODERNA, 2014) e nos itens da ANA se encontram nesse estágio inicial de compreensão da formação retangular: são problemas nos quais se explora a organização de elementos em disposição retangular e não medidas em si. Esse tipo de problema, embora possibilite que os alunos operem com base na ideia de proporcionalidade (2 grupos de 5 árvores) ou apoiados em ilustrações, é de fundamental importância para a construção do significado da fórmula da área de uma superfície retangular posteriormente (BRASIL, 2007).

A pesquisa conduzida por Gitirana et al. (2014) indica que problemas de configuração retangular - já mais sofisticados - que envolvem medidas, tais como "A sala de aula da Escola Divertida tem um formato retangular com 3 metros de largura e 5 metros de extensão. Qual é a área da sala de aula?" (GITIRANA et al., 2014, p.73) só são razoavelmente dominadas pelos alunos a partir do $4^{\circ}$ ano do ensino fundamental.

Um fato que chamou a atenção durante a análise documental é a pouca representatividade desta categoria da multiplicação nos itens elaborados para a ANA. Existem apenas dois deles disponíveis no BNI - o que equivale a pouco menos de $9 \%$ do total de itens da habilidade $\mathrm{H} 9$ - e, embora demandem $\mathrm{O}$ mesmo cálculo, um deles alcançou $50,4 \%$ de acerto enquanto o outro foi acertado por apenas $14,1 \%$ dos estudantes. Comum aos dois itens foi o fato de que grande parte das crianças que erraram (79,6\% em um deles e 43,2\% no outro) apontou como resposta a simples contagem dos elementos visíveis na 
ilustração, demonstrando falta de compreensão do problema como uma situação multiplicativa.

\subsection{Combinatória}

Assim como na ideia de configuração retangular, a combinatória implica uma relação ternária na qual uma quantidade é obtida como produto de outras duas (VERGNAUD, 2009a). Um exemplo desse tipo de situação é: "Tendo duas saias - uma preta e uma branca - e três blusas - uma rosa, uma azul e uma cinza -, de quantas maneiras diferentes posso me vestir?" (BRASIL, 1997, p.111, adaptado). Nesse caso, dois conjuntos básicos (saias e blusas) dão origem a um terceiro conjunto (trajes) pela correspondência sistemática entre cada saia e cada blusa (NUNES e BRYANT, 1997).

A análise dos documentos curriculares colocou em evidência a dificuldade diferenciada que essa categoria de problemas representa para os alunos. O livro didático (MODERNA, 2014) propõe uma abordagem da combinatória que vai da determinação de quais são as possibilidades para a quantificação destas, alertando que os professores não devem apressar os alunos a relacionar essas situações à multiplicação.

Já o exame dos itens que avaliam a habilidade $\mathrm{H} 9$ da ANA revela que as situações de combinação - que, pela natureza do instrumento, requerem um resultado numérico e, portanto, a quantificação das possibilidades - se destacam das demais pelo baixo nível de acertos obtidos (entre 8,4\% e 20,6\%), mesmo que os cálculos demandados tenham envolvido apenas números menores que seis. É impressionante o fato de que a diferença entre o item mais fácil de combinatória $(20,6 \%$ de acerto) e os itens mais difíceis envolvendo as ideias de proporcionalidade (32\% de acerto) ou multiplicação comparativa (31,3\% de acerto) é superior a $10 \%$. Também nesse caso se verifica a tendência de que a repetição dos valores dados no enunciado ou a soma deles se mostrem como distratores atrativos, sugerindo que os respondentes nem mesmo compreendem o problema como do tipo 
multiplicativo. Em cinco dos sete itens desta categoria a marcação de uma dessas alternativas superou os $40 \%$.

Nas entrevistas, as professoras participantes concordaram que uma ficha de combinatória apresentava a situação mais desafiadora para os alunos do $3^{\circ}$ ano do ensino fundamental, a saber:

Em uma barraquinha que servia sanduíche, era possível pedir com recheio de salsicha ou linguiça, com molho ou sem molho. De quantas maneiras era possível pedir um sanduíche?

P2 ponderou que problemas como este envolvem "mais um pouquinho de raciocínio" e que o livro traz "problemas parecidos e eles têm muita dificuldade". A professora ainda reconheceu a relevância da inclusão da combinatória em sala de aula e declarou que "trabalha muito [a combinação], o livro pede muito isso" (P2). Apesar do seu posicionamento, P2 selecionou apenas uma ficha de combinação dentre as oito que foi orientada a escolher para, hipoteticamente, trabalhar com sua turma.

A amostra de fichas construída por P1 também contou com apenas um problema de combinatória. Segundo ela, essas situações são difíceis para os alunos por demandarem abstração: "essa capacidade de criar, de imaginar o que vem depois, eles têm muita dificuldade" (P1).

As pesquisas na área referendam a percepção a respeito da complexidade da ideia de combinatória para as crianças (NUNES e BRYANT, 1997; PESSOA e MATOS FILHO, 2006; PESSOA e BORBA, 2009). Isso porque, nesses problemas, a correspondência entre os conjuntos básicos está implícita e precisa ser descoberta a partir do sentido da situação (NUNES e BRYANT, 1997; PESSOA e BORBA, 2009). A necessidade de operar com grupos, e não mais com unidades, também é considerada um dificultador, já que pode impactar a significação do problema pelo aluno (PESSOA e MATOS FILHO, 2006).

Mesmo quando os alunos compreendem a situação, eles geralmente encontram dificuldades para enumerar todas as possíveis combinações, não alcançando um resultado numérico final (PESSOA; BORBA, 2009). Esse 
cenário se relaciona com as considerações de P1 a respeito da capacidade de abstração das crianças nessa faixa etária: "imaginar o que vem depois" (P1) ainda é um obstáculo para elas.

Diante desses percalços, Gitirana et al. (2014) ressaltam a importância do trabalho com a tabela de dupla entrada e o diagrama de árvore, apontando que essas estratégias auxiliam o aluno a perceber a articulação da ideia de combinação com a multiplicação. O livro didático (MODERNA, 2014) e o Currículo em Movimento (GDF, 2013a) reconhecem a validade desses métodos - o segundo cita apenas a tabela de dupla entrada -, recomendando sua adoção pelos docentes.

Apesar da reconhecida complexidade da ideia de combinação, ela precisa ter seu espaço ainda no início da escolarização. Como bem lembram Pessoa e Borba (2009), mesmo que as crianças não cheguem a, de fato, resolver numericamente problemas do tipo, elas são capazes de compreender as relações neles envolvidas e devem ser estimuladas a fazê-lo desde cedo. Nunes e Bryant (1997) também argumentam que o estudo da combinação permite que as crianças expandam sua compreensão do campo multiplicativo.

Alinhados com esse pensamento, todos os documentos aqui analisados contemplaram a combinatória como conteúdo para $03^{\circ}$ ano do ensino fundamental, o que também foi reconhecido pelas professoras. Outros materiais curriculares nacionais, tais como os Direitos de Aprendizagem (BRASIL, 2012a), a Matriz de Referência da Provinha Brasil (BRASIL, 2016b) e os cadernos de formação do Pró-Letramento (BRASIL, 2008a) e PNAIC (BRASIL, 2014) também compartilham dessa convenção. No entanto, a proposta que consta na $2^{\underline{a}}$ versão da BNCC (BRASIL, 2016a) dá um passo atrás, restringindo a multiplicação nos três primeiros anos do ensino fundamental às ideias de proporcionalidade (usando a expressão "adição de parcelas iguais"), multiplicação comparativa (restrita aos conceitos de dobro e triplo) e disposição retangular. 


\subsection{Aspectos Didáticos}

\subsubsection{Sobre categorias e limitações}

O trabalho com a variedade de significados que as operações podem assumir está bem estabelecido nos diversos níveis curriculares que influem o ensino no primeiro ciclo dos anos iniciais do ensino fundamental: para além dos documentos analisados para os fins desta pesquisa, isto também foi constatado em materiais que serviram a eles como referência - PCN (BRASIL, 1997), Direitos de Aprendizagem (BRASIL, 2012a), cadernos do PróLetramento (BRASIL, 2008a) e PNAIC (BRASIL, 2014) e matriz da Provinha Brasil (BRASIL, 2016b) - ou, a partir deles, se originou - BNCC (BRASIL, 2016a).

Tal abordagem aproxima o currículo dos preceitos da Teoria dos Campos Conceituais (VERGNAUD, 1982, 1986, 1990, 1994, 2009a, 2009b). Alguns desses documentos, inclusive, declaram explicitamente essa base teórica - PCN (BRASIL, 1997), Direitos de Aprendizagem (BRASIL, 2012a), PNAIC (BRASIL, 2014) e Projeto Buriti Matemática (MODERNA, 2014). No entanto, é notável que, contrariamente ao que postula Vergnaud (1982, 1986, 1990, 1994, 2009a, 2009b), a opção, possivelmente didática, por separar a multiplicação e a divisão ainda é dominante. O esforço de integração promovido inicialmente pelos PCN (BRASIL, 1997) e presente também na matriz do Saeb (BRASIL, 2008b) - que concentra multiplicação e divisão em um único descritor - foi abandonado pelos documentos que vieram em seguida.

Aparentemente, também em sala de aula, perdura a segregação entre esses conceitos. A compreensão de que a divisão é mais difícil do que a multiplicação e, portanto, deve ser apresentada depois desta perpassa a seguinte declaração da professora P2: "esse ano, inclusive, nós já introduzimos a divisão porque eles estão pegando bem [a multiplicação]” (P2).

Essa crença, contudo, vem sendo contestada. Mulligan e Mitchelmore (1997) argumentam que as crianças relacionam espontaneamente a multiplicação à divisão e que não necessariamente consideram que esta última 
seja mais difícil. Os autores concluem que seria benéfico para os alunos se os professores estreitassem mais os laços entre multiplicação e divisão e oferecessem problemas envolvendo estes conceitos desde os anos iniciais de escolarização (MULLIGAN e MITCHELMORE, 1997). De forma similar, Van der Walle (2009) alerta para a importância de "combinar multiplicação e divisão logo após a multiplicação ser introduzida a fim de ajudar os estudantes a perceber como elas são relacionadas" (p.178).

Uma outra situação que deriva da absorção apenas parcial dos fundamentos da TCC (VERGNAUD, 1982, 1986, 1990, 1994, 2009a, 2009b) pelo currículo é a separação entre as ideias vinculadas à multiplicação e à divisão. Enquanto para a multiplicação são frequentemente apontadas pelo menos três interpretações possíveis (proporcionalidade, disposição retangular e combinação com o possível acréscimo da multiplicação comparativa), a divisão está usualmente restrita a duas ideias: partilha e medida - com variações dos termos usados para denominá-las.

Essa categorização, no entanto, não só limita a variedade de situações possíveis, mas também não promove da melhor forma a compreensão do vínculo entre multiplicação e divisão. É importante ressaltar que, num problema de configuração retangular como "Num pequeno auditório, as cadeiras estão dispostas em 7 fileiras e 8 colunas. Quantas cadeiras há no auditório?" (BRASIL, 1997, p.110), ao mudar o elemento desconhecido pode-se chegar a um enunciado como esse "As 56 cadeiras de um auditório estão dispostas em fileiras e colunas. Se são 7 as fileiras, quantas são as colunas?" (BRASIL, 1997, p.111), que está, a princípio, mais próximo da divisão. O mesmo pode ser feito a partir da alteração da incógnita em situações de multiplicação comparativa e combinação, resultando em problemas de divisão que vão além das ideias de partilha e medida.

Greer (1994) expressa preocupação com "o aparente pressuposto de que todos os problemas que importam podem ser abordados por um pequeno número de representações" (p.66, tradução nossa) argumentando que não está claro que seja "proveitoso ignorar distinções com importantes implicações psicológicas e pedagógicas" (GREER, 1994, p.66, tradução nossa). 
É compreensível que o recurso a categorizações mais sucintas e diferenciadas para a multiplicação e divisão apresente vantagens didáticas, uma vez que introduz importantes mudanças pedagógicas, como a ampliação do rol de situações a serem trabalhadas em sala de aula, sem romper completamente com as práticas cristalizadas para essa etapa do ensino. A preservação da nomenclatura "adição de parcelas iguais" pode ser tomada como exemplo: é feito o acréscimo de duas ou três ideias da multiplicação para além da proporcionalidade, mas admite-se que ela continue sendo tratada como uma continuação natural da adição, apesar do conflito teórico. É possível olhar da mesma forma para a separação entre multiplicação e divisão: ampliase o leque de significados associados a estas operações, mas preservam-se as divisas entre elas.

Algumas categorizações, no entanto, são capazes de conciliar ambas as funções: apresentar as possibilidades a serem exploradas de forma sintética e evidenciar a relação intrínseca entre multiplicação e divisão abordando, portanto, coerentemente o campo conceitual multiplicativo. Não se pode dizer que são modelos completos, mas servem bem ao que é possível trabalhar nos anos iniciais do ensino fundamental.

A classificação apresentada pelos PCN (BRASIL, 1997) - e que foi adotada como suporte para esta pesquisa - cumpre estes requisitos. O mesmo pode ser alegado a respeito do esquema apresentado por Gurgel (2009), formulado com a consultoria de Pires e Monteiro: 
FIGURA 4 - Classificação da multiplicação e da divisão

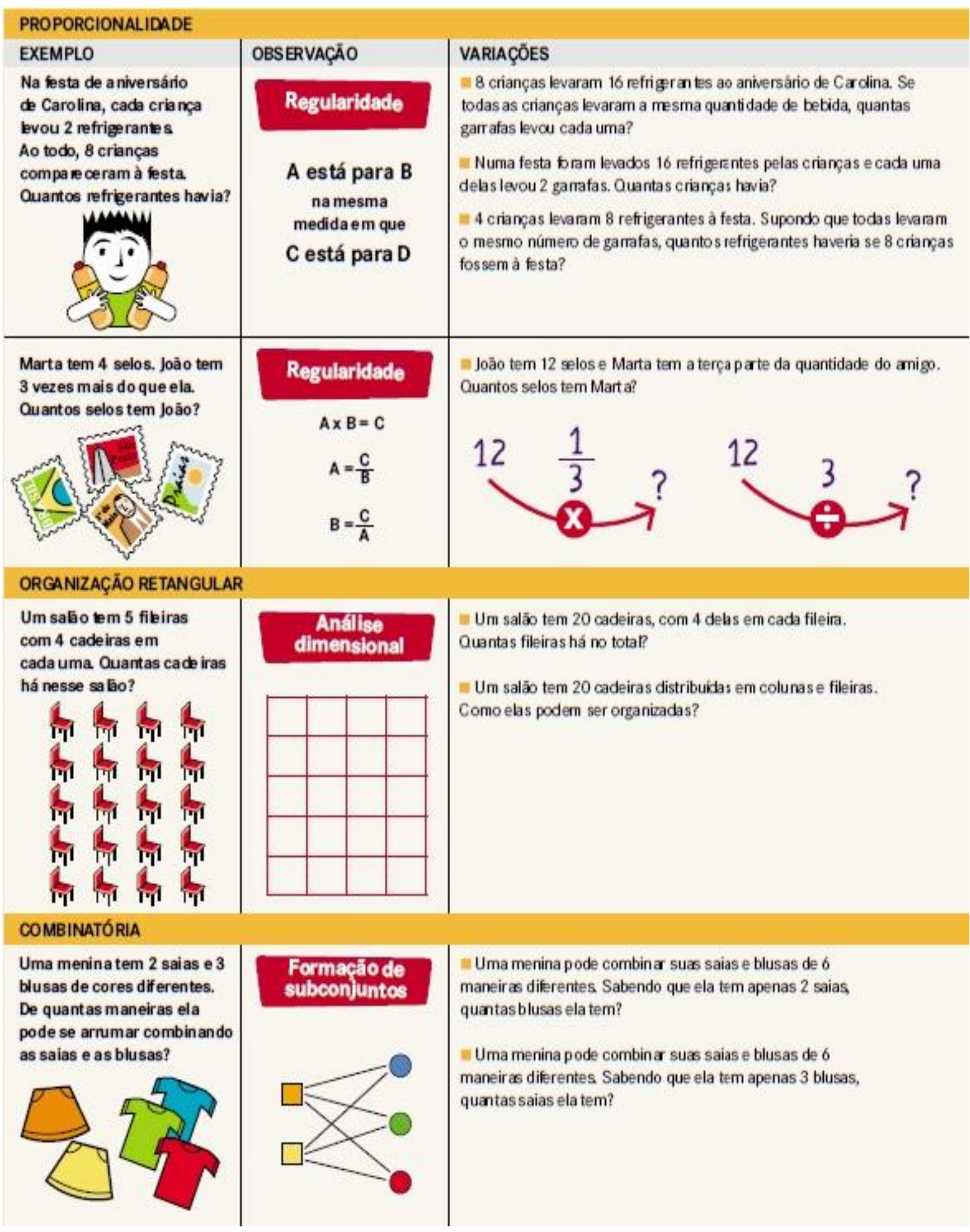

Fonte: Gurgel (2009)

Um outro exemplo é encontrado no quadro de situações comuns de multiplicação e divisão elaborado pela Common Core State Standards Initiative (COMMON CORE STATE STANDARDS INITIATIVE): 
QUADRO 5 - Situações comuns de multiplicação e divisão

\begin{tabular}{|c|c|c|c|}
\hline & $\begin{array}{c}\text { PRODUTO } \\
\text { DESCONHECIDO }\end{array}$ & $\begin{array}{c}\text { TAMANHO DO } \\
\text { GRUPO } \\
\text { DESCONHECIDO } \\
\text { (DIVISÃO “QUANTOS } \\
\text { EM CADA GRUPO?”) }\end{array}$ & $\begin{array}{l}\text { NÚMERO DE GRUPOS } \\
\text { DESCONHECIDO } \\
\text { (DIVISÃO “QUANTOS } \\
\text { GRUPOS?”) }\end{array}$ \\
\hline & $3 \times 6=?$ & $3 \times ?=18$ e $18 \div 3=?$ & $? \times 6=18$ e $18 \div 6=?$ \\
\hline $\begin{array}{l}\text { GRUPOS } \\
\text { IGUAIS }\end{array}$ & $\begin{array}{l}\text { Tenho } 3 \text { sacolas com } 6 \\
\text { ameixas em cada uma. } \\
\text { Quantas são as } \\
\text { ameixas ao todo? } \\
\text { Exemplo de medida. } \\
\text { Você precisa de } 3 \\
\text { pedaços de linha com } 6 \\
\text { cm de comprimento } \\
\text { cada. De quanta linha } \\
\text { você precisa ao todo? }\end{array}$ & $\begin{array}{l}\text { Se } 18 \text { ameixas forem } \\
\text { divididas igualmente em } \\
3 \text { sacolas, quantas } \\
\text { ameixas ficarão em } \\
\text { cada sacola? Exemplo } \\
\text { de medida. Você tem } \\
\text { uma linha de } 18 \mathrm{~cm} \mathrm{e} \\
\text { vai corta-la em } 3 \\
\text { pedaços iguais. Quanto } \\
\text { vai medir cada pedaço } \\
\text { de linha? }\end{array}$ & $\begin{array}{l}\text { Se } 18 \text { ameixas forem } \\
\text { guardadas de } 6 \text { em } 6 \\
\text { nas sacolas, quantas } \\
\text { sacolas serão } \\
\text { necessárias? Exemplo } \\
\text { de medida. Você tem } \\
\text { uma linha de } 18 \mathrm{~cm} \text { e } \\
\text { vai corta-la em pedaços } \\
\text { de } 6 \mathrm{~cm} \text { de } \\
\text { comprimento. Quantos } \\
\text { pedaços de linha você } \\
\text { terá? }\end{array}$ \\
\hline MALHA, ÁREA & $\begin{array}{l}\text { As maçãs estão } \\
\text { organizadas em } 3 \\
\text { fileiras com } 6 \text { maçãs } \\
\text { em cada uma. Quantas } \\
\text { são as maçãs? } \\
\text { Exemplo de área. Qual } \\
\text { é a área de um } \\
\text { retângulo de } 3 \mathrm{~cm} \text { por } 6 \\
\mathrm{~cm} \text { ? }\end{array}$ & $\begin{array}{l}\text { Se } 18 \text { maçãs forem } \\
\text { organizadas em } 3 \\
\text { fileiras iguais, quantas } \\
\text { maçãs ficarão em cada } \\
\text { fileira? Exemplo de } \\
\text { área. Um retângulo tem } \\
18 \text { centímetros } \\
\text { quadrados de área. Se } \\
\text { um lado mede } 3 \mathrm{~cm} \text {, } \\
\text { quanto mede o lado } \\
\text { próximo a ele? }\end{array}$ & $\begin{array}{l}\text { Se } 18 \text { maçãs forem } \\
\text { organizadas em fileiras } \\
\text { de } 6 \text { maçãs cada, } \\
\text { quantas serão as } \\
\text { fileiras? Exemplo de } \\
\text { área. Um retângulo tem } \\
18 \text { centímetros } \\
\text { quadrados de área. Se } \\
\text { um lado mede } 6 \mathrm{~cm} \text {, } \\
\text { quanto mede o lado } \\
\text { próximo a ele? }\end{array}$ \\
\hline COMPARAÇÃO & $\begin{array}{l}\text { Um chapéu azul custa } \\
\mathrm{R} \$ 6,00 \text {. Um chapéu } \\
\text { vermelho custa } 3 \text { vezes } \\
\text { mais que o chapéu } \\
\text { azul. Quanto custa o } \\
\text { chapéu vermelho? } \\
\text { Exemplo de medida. } \\
\text { Um elástico tem } 6 \mathrm{~cm} \\
\text { de comprimento. } \\
\text { Quanto ele medirá se } \\
\text { for esticado por } 3 \text { vezes } \\
\text { o seu tamanho? }\end{array}$ & $\begin{array}{l}\text { Um chapéu vermelho } \\
\text { custa } \mathrm{R} \$ 18,00 \text { e isso é } \\
\text { o triplo do preço do } \\
\text { chapéu azul. Quanto } \\
\text { custa o chapéu azul? } \\
\text { Exemplo de medida. } \\
\text { Um elástico foi esticado } \\
\text { até atingir } 18 \mathrm{~cm} \text { de } \\
\text { comprimento e isso é } 3 \\
\text { vezes o seu tamanho } \\
\text { original. Qual o } \\
\text { comprimento original do } \\
\text { elástico? }\end{array}$ & $\begin{array}{l}\text { Um chapéu vermelho } \\
\text { custa } R \$ 18,00 \text { e um } \\
\text { chapéu azul custa } R \$ \\
6,00 \text {. O chapéu } \\
\text { vermelho custa quantas } \\
\text { vezes mais que o } \\
\text { chapéu azul? Exemplo } \\
\text { de medida. Um elástico } \\
\text { tinha } 6 \mathrm{~cm} \text { de } \\
\text { comprimento. Ele foi } \\
\text { esticado até alcançar } \\
18 \text { cm de comprimento. } \\
\text { O elástico esticado } \\
\text { mede quantas vezes } \\
\text { mais o seu tamanho } \\
\text { original? }\end{array}$ \\
\hline GERAL & $a \times b=?$ & $a \times ?=p$ e $p \div a=?$ & $? \times b=p$ e $p \div b=?$ \\
\hline
\end{tabular}

Fonte: Common Core State Standards Initiative (tradução nossa) 


\subsubsection{Sobre compreender e operar}

Uma preocupação presente em vários dos níveis curriculares aqui analisados diz respeito à compreensão das situações multiplicativas pelas crianças. O Currículo em Movimento (GDF, 2013a) lança como objetivo para o 30 ano do ensino fundamental "compreender e aplicar diferentes ideias de multiplicação" (p.80). O livro didático, coerente com essa prescrição, fornece atividades e orientações aos professores com o intuito de levar os alunos a perceber regularidades e relações envolvidas nas situações de multiplicação. Essa recomendação, que passa pelo currículo prescrito e apresentado, parece influir o currículo moldado uma vez que, no discurso das professoras participantes, fica evidente que a compreensão das situações-problema é muito valorizada por elas e pauta suas escolhas didáticas (uso de material concreto e desenhos):

"No começo também, além de usar o material concreto, eles
desenham. Antes de eu partir pra cobrar a memorização, eles
desenham a multiplicação, eles entendem que duas vezes o
três, por exemplo, é diferente de três vezes o dois, apesar de
ter o mesmo resultado" (P1).
"Eu vejo que tem criança que sabe assim de cor, mas não
entende como funciona, então a gente faz muita questão que
eles desenhem pra ver se eles realmente compreenderam que,
por exemplo, duas vezes o três é fazer o três e depois o três
novamente, que é adição de parcelas iguais. Eles têm que ter
essa compreensão, tanto na multiplicação quanto na divisão,
então uso muito material concreto e desenho, ilustração,
bastante, até eles compreenderem mesmo" (P2).

É reconhecido que o cálculo em si é apenas um dos aspectos relevantes ao lidar com uma situação-problema (VERGNAUD, 1979; THOMPSON, 1993, NUNES et al., 2011). Compreendê-la para, então, identificar a operação necessária é um forte critério para a construção de conceitos e é, também, a etapa na qual os alunos encontram as maiores dificuldades (VERGNAUD, 1979). É nesse sentido que Vergnaud (1979) diferencia cálculo numérico e cálculo relacional: o primeiro diz respeito à propriedade com que as "contas" são efetuadas enquanto o segundo se refere à interpretação das relações imbricadas na situação dada, que leva ao reconhecimento da operação aritmética requisitada. 
A distinção entre essas etapas ajuda a entender porque os alunos do ciclo inicial do ensino fundamental podem facilmente operar $2 \times 3$ numa situação de proporcionalidade, mas não alcançam o mesmo sucesso quando este cálculo é solicitado num problema de combinação: embora o cálculo numérico seja o mesmo, o cálculo relacional muda significativamente.

Quando o currículo estabelece, em seus diversos níveis, a importância de que os alunos compreendam as situações-problema, o cálculo relacional ganha espaço na sala de aula, garantindo aos alunos melhores condições para, de fato, dominarem o conceito da multiplicação em sua complexidade. 


\section{CONSIDERAÇÕES FINAIS}

Esta pesquisa teve como objetivo geral verificar se há compatibilidade na abordagem da multiplicação em diferentes níveis do currículo do $3^{\circ}$ ano do Ensino Fundamental em uma escola pública do Distrito Federal. Para isso, foi investigada a abordagem da multiplicação em diversos níveis curriculares (SACRISTÁN, 2000): o currículo prescrito, representado pelo Currículo em Movimento; o currículo apresentado, na figura do livro didático; o currículo moldado, aferido por meio de entrevistas com duas professoras e o currículo avaliado, expresso pela matriz da ANA. A análise se apoiou teoricamente na TCC (VERGNAUD, 1982, 1986, 1990, 1994, 2009a, 2009b), uma vez que os pressupostos desta teoria alcançaram grande penetração no cenário educacional brasileiro no que diz respeito ao ensino de matemática.

A análise documental e as entrevistas semiestruturadas mostraram-se escolhas metodológicas adequadas, embora a baixa adesão das professoras à participação tenha representado um grande desafio à condução da pesquisa.

Constatou-se que a abordagem da multiplicação nos diferentes materiais curriculares analisados se dá de forma congruente. Em todos eles, o conceito de multiplicação é ampliado para além da proporcionalidade e são contempladas, com mais ou menos ênfase, as mesmas interpretações desta operação, como sistematizado no Quadro 6: 
QUADRO 6 - Classificação dos problemas nos documentos analisados

\begin{tabular}{|c|c|c|c|c|}
\hline \multicolumn{5}{|c|}{ CLASSIFICAÇÃO DOS PROBLEMAS } \\
\hline VERGNAUD & PCN & LIVRO DIDÁTICO & MATRIZ ANA & $\begin{array}{l}\text { CURRÍCULO EM } \\
\text { MOVIMENTO }\end{array}$ \\
\hline $\begin{array}{c}\text { Caso de um } \\
\text { único espaço de } \\
\text { medidas } \\
\text { (multiplicação) }\end{array}$ & $\begin{array}{l}\text { Multiplicação } \\
\text { comparativa } \\
\text { (multiplicação) }\end{array}$ & $\begin{array}{l}\text { Dobro, triplo, } \\
\text { quádruplo e } \\
\text { quíntuplo }\end{array}$ & $\begin{array}{c}\text { Proporcionalida } \\
\text { de (dobro, triplo } \\
\text { etc.) }\end{array}$ & - \\
\hline $\begin{array}{l}\text { Isomorfismo de } \\
\text { medidas } \\
\text { (multiplicação) }\end{array}$ & $\begin{array}{l}\text { Proporcionalidad } \\
\text { e (multiplicação) }\end{array}$ & $\begin{array}{c}\text { Adição de parcelas } \\
\text { iguais/ } \\
\text { Proporcionalidade } \\
\text { (nos casos em que } \\
\text { não é fornecido o } \\
\text { valor unitário) }\end{array}$ & $\begin{array}{c}\text { Adição de } \\
\text { parcelas iguais }\end{array}$ & $\begin{array}{l}\text { Repetição de } \\
\text { parcelas iguais }\end{array}$ \\
\hline \multirow{2}{*}{$\begin{array}{l}\text { Produto de } \\
\text { medidas } \\
\text { (multiplicação) }\end{array}$} & $\begin{array}{l}\text { Configuração } \\
\text { retangular } \\
\text { (multiplicação) }\end{array}$ & $\begin{array}{l}\text { Disposição } \\
\text { retangular }\end{array}$ & $\begin{array}{l}\text { Disposição } \\
\text { retangular }\end{array}$ & $\begin{array}{l}\text { Representação } \\
\text { retangular }\end{array}$ \\
\hline & $\begin{array}{l}\text { Combinatória } \\
\text { (multiplicação) }\end{array}$ & Combinação & Combinação & Combinação \\
\hline
\end{tabular}

Fonte: elaboração própria

O esforço no sentido da superação do reducionismo conceitual (MUNIZ, 2009) verificado nesses materiais alcança o currículo moldado e se faz presente no discurso das professoras participantes, que demonstraram reconhecer a importância de incluir situações de multiplicação diversas em suas aulas.

Foi apurado ainda que, em todos os níveis curriculares discutidos para os fins desta pesquisa, a proporcionalidade foi definida como "adição de parcelas iguais" ou algo equivalente. Sobre isso, considerou-se que essa opção está carregada de sentidos que contrariam o entendimento da multiplicação dentro de um campo conceitual e não contribuem para a construção desse conceito.

Também na contramão da assunção do ensino da multiplicação na perspectiva dos campos conceituais, foi observado que o currículo, nas 
diferentes etapas aqui analisadas, insistiu na separação entre multiplicação e divisão, determinando categorias de situações diferentes para uma e outra operação. Essa decisão exclui um rol significativo de situações multiplicativas que podem ser obtidas pela alteração da incógnita em cada uma das classes de problemas discutidas ao longo deste trabalho e que contribuem para a compreensão das relações entre multiplicação e divisão. Apesar de reconhecer a relevância didática desta estratégia de apresentação, considerou-se que existem alternativas igualmente didáticas que ampliam, positivamente, as possibilidades de trabalho com o campo multiplicativo no ciclo inicial do ensino fundamental.

Essas considerações levam à conclusão de que, apesar das significativas mudanças que os ideais da TCC (VERGNAUD,1982, 1986, 1990, 1994, 2009a, 2009b) introduziram nos diversos âmbitos curriculares, algumas práticas e concepções já cristalizadas não chegaram a ser contestadas, apesar de não serem as mais condizentes com esses ideais.

No decorrer da pesquisa, novos questionamentos foram semeados. Dentre eles, pode-se destacar o seguinte como motivador de investigações futuras: qual o nível de domínio da multiplicação que se pode esperar das crianças ao fim do $3^{\circ}$ ano do ensino fundamental?

Os materiais analisados revelaram expectativas diferentes em relação a isso: enquanto as professoras e o Currículo em Movimento parecem estar mais preocupados com a compreensão das diferentes ideias da multiplicação pelos alunos, ainda que em situações mais simples e sem apressar a formalização de procedimentos de cálculo, a ANA avalia os alunos pela obtenção de resultados numéricos e o livro didático avança consideravelmente na complexidade dos problemas - que podem envolver números de três algarismos e probabilidade sem o valor unitário explícito, por exemplo - e alcança os algoritmos formais da multiplicação e da divisão.

Essa discussão deverá levar em conta que cada uma das interpretações da multiplicação oferece aos alunos um nível diferenciado de dificuldade e que a formação desses conceitos se dá ao longo de vários anos (VERGNAUD, 1982). 


\section{REFERÊNCIAS}

BARDIN, L. Análise de conteúdo. Lisboa: LDA, 2009.

Boletim de Educação Matemática. Rio Claro, v.29, n.52, 2014. Disponível em: <http://dx.doi.org/10.1590/1980-4415v28n49e02>. Acesso em: 10 out. 2015.

BRASIL. Secretaria de Educação Fundamental. Parâmetros curriculares nacionais: matemática. Brasília: MEC/SEF, 1997.

. Ministério da Educação. Programa gestão da aprendizagem escolar: Gestar I: matemática. Caderno de teoria e prática 3: operações com números naturais. Brasília: MEC, 2007.

. Ministério da Educação. Pró-Letramento: Programa de Formação Continuada de Professores dos Anos/Séries Iniciais do Ensino Fundamental: matemática. Brasília: MEC, 2008a.

. Instituto Nacional de Estudos e Pesquisas Educacionais Anísio Teixeira (Inep). PDE: Plano de Desenvolvimento da Educação: SAEB. Brasília: Inep, 2008b.

. Ministério da Educação. Resolução no 4, de 13 de julho de 2010. Dispõe sobre as Diretrizes Curriculares Nacionais Gerais para a Educação Básica, 2010.

. Ministério da Educação. Elementos conceituais e metodológicos para definição dos direitos de aprendizagem e desenvolvimento do ciclo de alfabetização (1ํㅜㄴ $2^{\circ}$ e $3^{\circ}$ anos) do ensino fundamental. Brasília: MEC, 2012a.

. Ministério da Educação. Resolução no 42, de 28 de agosto de 2012. Dispõe sobre o Programa Nacional do Livro Didático (PNLD) para a educação básica, 2012b.

. Instituto Nacional de Estudos e Pesquisas Educacionais Anísio Teixeira (Inep). Guia de elaboração de itens: Provinha Brasil. Brasília: Inep, 2012c.

. Ministério da Educação. Pacto nacional pela alfabetização na idade certa. Brasília: MEC, 2013a.

. Instituto Nacional de Estudos e Pesquisas Educacionais Anísio Teixeira (Inep). Avaliação Nacional da Alfabetização ANA: Documento Básico. Brasília: Inep, 2013b.

. Ministério da Educação. Pacto nacional pela alfabetização na idade certa: operações na resolução de problemas. Brasília: MEC, 2014. MEC, 2015.

Ministério da Educação. Guia de livros didáticos: PNLD 2016. Brasília:

. Ministério da Educação. Base nacional comum curricular: $2^{a}$ versão.

Brasília: MEC, 2016a. 
. Instituto Nacional de Estudos e Pesquisas Educacionais Anísio Teixeira (Inep). Guia de Correção e Interpretação de Resultados da Provinha Brasil. Brasília: Inep, 2016b.

CELLARD, A. A análise documental. In: POUPART, J. et al. A pesquisa qualitativa: enfoques epistemológicos e metodológicos. Petrópolis: Vozes, 2012.

CHIZZOTTI, A. Pesquisa em ciências humanas e sociais. São Paulo: Cortez, 2001.

COMMON CORE STATE STANDARDS INITIATIVE. Mathematics Glossary: Table 2. Disponível em:

<http://www.corestandards.org/Math/Content/mathematics-glossary/Table-2/>. Acesso em: out. 2016.

DENZIN, N. K.; LINCOLN, Y. S. O planejamento da pesquisa qualitativa: teorias e abordagens. $2^{\mathrm{a}}$ Ed. Porto Alegre: Artmed, 2006.

FIORENTINI, D.; LORENZATO, S. Investigação em educação matemática: percursos teóricos e metodológicos. Campinas: Autores Associados, 2012.

FLICK, U. Uma introdução à pesquisa qualitativa. 3를. Porto Alegre: Artmed, 2009.

FRANCHI, A. Considerações sobre a Teoria dos Campos Conceituais. In: FRANCHI, A. et al. Educação Matemática: uma introdução. São Paulo: EDUC, 1999.

FRANCO, M. L. P. B. Análise de conteúdo. Brasília: Liber Livro, 2012.

FRASER, M. T. D.; GONDIM, S. M. G. Da fala do outro ao conteúdo negociado: discussões sobre a entrevista na pesquisa qualitativa. Paideia, 14(28), 139152, 2004.

GITIRANA, V. et al. Repensando a multiplicação e divisão: contribuições da Teoria dos Campos Conceituais. São Paulo: PROEM, 2014.

GOVERNO DO DISTRITO FEDERAL. Secretaria de Estado e Educação do Distrito Federal. Diretrizes pedagógicas do bloco inicial de alfabetização. brasília: SEEDF, 2012.

. Secretaria de Estado e Educação do Distrito Federal. Currículo em movimento da educação básica: Ensino Fundamental Anos Iniciais. Brasília: SEEDF, 2013a.

. Secretaria de Estado e Educação. Currículo em movimento da educação básica: Pressupostos Teóricos. Brasília: SEEDF, 2013b.

GREER, B. Extending the Meaning of Multiplication and Division. In: HAREL, G.; CONFREY, J. (Orgs.). The development of multiplicative reasoning in the learning of mathematics. Albany: State University of New York Press,1994. 
GUERIOS, E. C. et al. Situações aditivas e multiplicativas no ciclo de alfabetização. In: BRASIL. Pacto Nacional pela Alfabetização na Idade Certa: Operações na resolução de problemas. Brasília: MEC, SEB, 2014.

GURGEL, T. Multiplicação e divisão já nas séries iniciais. Disponível em: $<$ https://novaescola.org.br/conteudo/2662/multiplicacao-e-divisao-ja-nas-seriesiniciais>. Acesso em: out. 2016.

LI, Y.; LAPPAN,G. Mathematics curriculum in school education. Springer, 2014. LÜDKE, M; ANDRÉ, M. E. D. A. Pesquisa em educação: abordagens qualitativas. São Paulo: EPU, 1986.

MALTA, S. C. L. Uma abordagem sobre currículo e teorias afins visando à compreensão e mudança. Espaço do Currículo, v. 6, n. 2, p. 340-354, 2013. Disponível em: <http://periodicos.ufpb.br/ojs2/index.php/rec>. Acesso em: 10 out. 2015.

MODERNA. Projeto Buriti: Matemática 3ํano: Manual do Professor. São Paulo: Moderna, 2014.

MONTEIRO, P. Matemática é $D+$ ! : somar ou multiplicar?. Disponível em: $<\mathrm{https}: / /$ www.youtube.com/watch?v=hZ8g5Y7kzpQ>. Acesso em: out. 2016.

MORETTI, V. D.; SOUZA, N. M. M. Educação matemática nos anos iniciais do ensino fundamental: Princípios e práticas pedagógicas. São Paulo: Cortez, 2015.

MULLIGAN, J. T.; MITCHELMORE, M. C. Young Children's Intuitive Models of Multiplication and Division. Journal for Research in Mathematics Education, v. 28, n. 3, p. 309-330, 1997.

MUNIZ, C. A. Diversidade dos conceitos das operações e suas implicações nas resoluções de classe de situações. In: GUIMARÃES, G.; BORBA, Rute (Orgs.). Reflexões sobre o ensino de matemática nos anos iniciais de escolarização. Recife: SBEM, v. 1, p. 101-118, 2009.

NUNES, T.; BRYANT, P. Crianças fazendo matemática. Porto Alegre: Artes Médicas, 1997.

NUNES, T. et al. P. Educação Matemática: número e operações numéricas. São Paulo: Cortez, 2009.

NUNES, T. et al. Teaching children how to include the inversion principle in their reasoning about quantitative relations. Educational Studies in Mathematics, v. 79, n. 3, p. 371-388, 2011.

PEDRA, J. A. Currículo, conhecimento e suas representações. Campinas: Papirus, 1997.

PESSOA, C.; BORBA, R. Quem dança com quem: o desenvolvimento do raciocínio combinatório de crianças de $1^{\text {a }}$ a $4^{\text {a }}$ série. Zetetiké, v. 17, n. 31, 2009. 
PESSOA, C. A. S.; MATOS FILHO, M. A. S. Estruturas Multiplicativas: como os alunos compreendem os diferentes tipos de problemas? In: Anais do SIPEMAT. Recife, Programa de Pós-Graduação em Educação, Universidade Federal de Pernambuco, 2006.

PIRES, C. M. C.; CURI, E. Relações entre professores que ensinam matemática e prescrições curriculares. REnCiMa, v. 4, n. 2, p. 57-74, 2013. Disponível em: $<$ http://revistapos.cruzeirodosul.edu.br/index.php/rencima/article/viewFile/825/6 95 >. Acesso em: 10 abr. 2015.

REMILLARD, J. T. et al. Mathematics teachers at work: connecting curriculum materials and classroom instruction. New York: Routledge, 2009.

SACRISTÁN, J. G. O currículo: uma reflexão sobre a prática. Porto Alegre: Artmed, 2000.

SÁNCHEZ GAMBOA, S. Pesquisa em Educação: métodos e epistemologias. Chapecó: Argos, 2012.

SANTOMÉ, J. T. Globalização e interdisciplinaridade: o currículo integrado. Porto Alegre: Editora Artes Médicas Sul, 1998.

SANTOS, A. et al.O campo conceitual das estruturas multiplicativas: análise comparativa entre o prognóstico dos professores e o desempenho dos estudantes. In: VII Congreso Iberoamericano de Educacíon Matemática. Montevideo: Sociedad de Educacion Matematica Uruguaya, v. 1. p. 2745-2751, 2013.

SILVA, T. T. Documentos de identidade: uma introdução às teorias do currículo. Belo Horizonte: Autêntica, 2005.

THOMPSON, P. W. Quantitative reasoning, complexity, and additive structures. Educational Studies in Mathematics, v. 25, n. 3, p. 165-208, 1993.

TRIVIÑOS, A. N. S. Introdução à pesquisa em ciências sociais: a pesquisa qualitativa em educação. São Paulo: Editora Atlas, 1987.

VAN DER WALLE, J. A. Matemática no ensino fundamental: formação de professores e aplicação em sala de aula. Porto Alegre: Artmed Editora, 2009.

VECE, J. P.; CURI, E. Professores dos três primeiros anos do ensino fundamental da rede municipal de São Paulo e suas relações com o currículo prescrito e apresentado no ensino de matemática. Bolema, Rio Claro, v. 28, n. 49, p. 621-637, ago. 2014. Disponível em:

$<$ http://www.scielo.br/scielo.php?script=sci_arttext\&pid=S0103636X2014000200621\&lng=en\&nrm=iso\&tlng=pt >. Acesso em: 10 abr. 2015.

VERGNAUD, G. The acquisition of arithmetical concepts. Educational Studies in Mathematics, v. 10, n. 2, p. 263-274, 1979.

. Cognitive and developmental psychology and research in mathematics education: some theoretical and methodological issues. Montreal: FLM Publishing Association, 1982. 
. Psicologia do desenvolvimento cognitivo e didáctica das matemáticas. Um exemplo: as estruturas aditivas. Análise Psicológica, v. 1, n. 5, p. 75-90, 1986.

. La Teoría de los Campos Conceptuales. Recherches en Didáctique des Mathèmatiques, v. 10, n. 2, p. 133-170, 1990.

Multiplicative conceptual field: what and why? In: HAREL, G.; CONFREY, J. (Orgs.). The development of multiplicative reasoning in the learning of mathematics. Albany: State University of New York Press,1994.

A criança, a matemática e a realidade: problemas do ensino de matemática na escola elementar. Curitiba: EdUFPR, 2009a.

The theory of conceptual fields. Human Development, v. 52, n. 2, 2009b.

ZANELLA, A. V. et al. Questões de método em textos de Vygotski: contribuições à pesquisa em psicologia. Psicologia \& Sociedade, 19, 25-33. 2007. 


\section{APÊNDICE A}

\section{TERMO DE CONSENTIMENTO LIVRE E ESCLARECIDO}

Você está sendo convidado (a) para participar da pesquisa intitulada "Ideias da Multiplicação no Currículo dos Anos Iniciais do Ensino Fundamental", sob a responsabilidade dos pesquisadores Clara Machado da Silva Alarcão e Cleyton Hércules Gontijo. Nesta pesquisa, estamos buscando entender como o currículo se relaciona com o ensino da multiplicação nos anos iniciais do Ensino Fundamental. A sua participação consistirá em conceder entrevistas que serão registradas em áudio e vídeo. Após a transcrição desse material, as gravações serão eliminadas. Em nenhum momento você será identificado. Os resultados da pesquisa serão publicados e ainda assim a sua identidade será preservada. Você não terá nenhum gasto ou ganho financeiro por participar na pesquisa. Você é livre para deixar de participar da pesquisa a qualquer momento sem nenhum prejuízo ou coação. Uma via original deste Termo de Consentimento Livre e Esclarecido ficará com você. Havendo qualquer dúvida a respeito da pesquisa, você poderá entrar em contato com: Clara Machado da Silva pelo telefone $(X X) \quad X X X X X X X X X$ ou pelo endereço de e-mail xxxxxxxxxxxx@hotmail.com.

Brasília, de de 2016

\section{Assinatura dos pesquisadores}

Eu aceito participar do projeto citado acima, voluntariamente, após ter sido devidamente esclarecido. 


\section{APÊNDICE B}

\section{REQUERIMENTO DE ACESSO AOS ITENS}

\section{Ao Senhor Diretor de Avaliação da Educação Básica}

Eu, Clara Machado da Silva Alarcão, matrícula no XXXXX, ocupante do cargo de Pesquisador-Tecnologista, atualmente lotada na Coordenação Geral de Exames para Certificação - CGEC da Diretoria de Avaliação da Educação Básica - DAEB, venho requerer, para fins de pesquisa junto ao Programa de Pós-Graduação em Educação da Universidade de Brasília com vistas à obtenção do título de mestre, acesso a informações sigilosas a respeito dos itens pré-testados para compor a Avaliação Nacional da Alfabetização - ANA.

A pesquisa em questão tem como objetivo analisar como os diversos níveis curriculares incidem sobre as práticas docentes em relação ao ensino das situações multiplicativas no primeiro ciclo dos anos iniciais do Ensino Fundamental. A ANA, nesse contexto, é compreendida enquanto currículo avaliado.

Para atender ao objetivo específico de investigar a abordagem das diferentes ideias da multiplicação pela ANA, existe a necessidade de analisar os itens pré-testados nos anos 2014 e 2015 referentes à habilidade H9 Resolver problemas que envolvam as ideias da multiplicação.

Os itens serão classificados de acordo com as categorias formuladas a partir da Teoria dos Campos Conceituais. Esse exercício inicial permitirá verificar em que medida a variedade de ideias da multiplicação vem sendo contemplada na elaboração de itens. Em um segundo momento, com o apoio das informações psicométricas, será investigado se o pressuposto teórico de que as diferentes ideias da multiplicação representam, também, diferentes níveis de dificuldade para os alunos se confirma no âmbito da avaliação em larga escala.

Cumpre ressaltar que o relatório de pesquisa apresentará somente a análise pedagógica dos itens, considerando suas características e informações psicométricas e relacionando-as com o referencial teórico adotado e, portanto, os itens permaneceriam sigilosos. A referência a esse material, no texto da dissertação, será ao conjunto de itens de uma categoria, preservando assim as características particulares dos itens que poderiam identifica-los.

As informações geradas a partir dessa análise serão de grande importância para a ampliação do conhecimento a respeito do ensino e aprendizagem da multiplicação, uma vez que permitirão traçar um panorama amplo da construção desse conhecimento pelos alunos dos anos iniciais do Ensino Fundamental.

Nestes termos, peço deferimento.

$$
\text { Brasília, ....... de ........de } 2016
$$

\section{Clara Machado da Silva Alarcão}

Pesquisadora-Tecnologista em Informações e Avaliações Educacionais 


\section{APÊNDICE C}

\section{ROTEIRO PARA AS ENTREVISTAS SEMIESTRUTURADAS}

\section{Parte 1: Informações para caracterização dos participantes}

\begin{tabular}{|c|c|c|c|}
\hline \multicolumn{4}{|c|}{ DADOS PESSOAIS } \\
\hline \multicolumn{4}{|l|}{ Nome completo: } \\
\hline \multicolumn{2}{|l|}{ Idade: } & \multicolumn{2}{|c|}{ Sexo: ( ) feminino ( ) masculino } \\
\hline \multicolumn{4}{|c|}{ Telefone para contato: } \\
\hline \multicolumn{4}{|l|}{ E-mail: } \\
\hline \multicolumn{4}{|c|}{ DADOS PROFISSIONAIS } \\
\hline PROFESSOR & ( ) efetivo & \multicolumn{2}{|l|}{ ( ) temporário } \\
\hline \multicolumn{4}{|c|}{ FORMAÇÃO } \\
\hline NÍVEL & $\begin{array}{c}\text { ANO DE } \\
\text { CONCLUSÃO }\end{array}$ & INSTITUIÇÃO & ÁREA \\
\hline \multicolumn{4}{|l|}{ ( ) magistério } \\
\hline \multicolumn{4}{|l|}{ ( ) graduação } \\
\hline \multicolumn{4}{|c|}{ ( ) especialização } \\
\hline \multicolumn{4}{|l|}{ ( ) mestrado } \\
\hline \multicolumn{4}{|l|}{ ( ) doutorado } \\
\hline \multicolumn{4}{|l|}{ ( ) outros } \\
\hline \multicolumn{4}{|c|}{ Tempo de experiência na docência: } \\
\hline \multicolumn{4}{|c|}{ Tempo de atuação na Secretaria de Educação do DF: } \\
\hline \multicolumn{4}{|c|}{ Tempo de experiência nos anos iniciais do E.F.: } \\
\hline \multicolumn{4}{|c|}{ № de alunos em sala de aula: } \\
\hline \multicolumn{3}{|c|}{$\begin{array}{l}\text { Algum aluno recebe atendimento especializado? } \\
\text { ( ) } \operatorname{sim} \text { ( ) não }\end{array}$} & Quantos? \\
\hline $\begin{array}{l}\text { Fez algum curs } \\
\text { ( ) sim ( ) nãc } \\
\text { Qual? }\end{array}$ & área de Educaçãc & Matemática? & \\
\hline
\end{tabular}




\section{Parte II: Questões}

1. Você ensina multiplicação no $3^{\circ}$ ano? Por quê?

2. Você gosta de ensinar multiplicação?

3. Os seus alunos já sabem multiplicar?

4. Seus alunos gostam de aprender multiplicação? É difícil para eles?

5. Que recursos você gosta de usar para ensinar multiplicação?

6. Onde você busca materiais para trabalhar a multiplicação em sala de aula?

7. Você conhece a ANA ou a Provinha? Você acha que a forma como elas cobram a multiplicação é compatível com o que os alunos sabem fazer?

8. Quais dessas situações (fichas) você selecionaria para usar na sua aula?

9. Em quais dessas situações (fichas) você acha que seus alunos teriam mais sucesso? E em quais teriam mais dificuldade? 


\section{APÊNDICE D}

\section{PROBLEMAS UTILIZADOS PARA AS FICHAS}

\section{Multiplicação Comparativa}

Marta tem 4 selos e João tem 5 vezes mais selos que ela. Quantos selos tem João?

$(\mathrm{PCN})$

Veja os doces que Carina fez para a festa da escola.

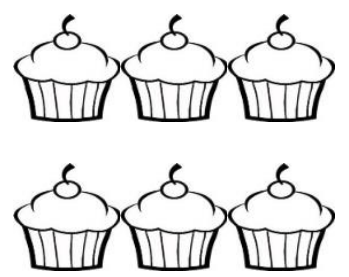

Sara fez o dobro dessa quantidade de doces. Quantos doces Sara fez?

(PROVINHA)

Marina tem 3 bonecas e Dani tem o dobro dessa quantidade de bonecas. Quantas bonecas Dani tem?

(PROVINHA)

Uma loja do Shopping vende tudo 3 vezes mais caro que a lojinha da esquina. Uma sandália custa $R \$ 4,00$ na lojinha da esquina. Quanto a mesma sandália custa na loja do Shopping?

(GITIRANA)

Larissa tem 6 anos. O pai de Larissa é 5 vezes mais velho do que ela. Quantos anos ele tem?

\section{Proporcionalidade}

Para fazer um bolo, a receita de Luísa leva 4 ovos. Luísa quer fazer 2 bolos usando essa receita. Quantos ovos ela vai usar? 
(PROVINHA)

Maria ganhou 3 cadernos e, para enfeita-los, colou 5 adesivos em cada.

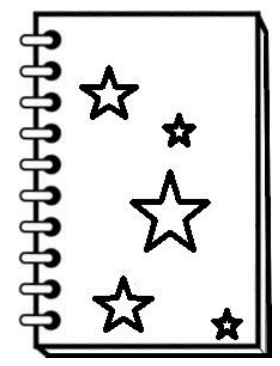

Quantos adesivos Maria usou para enfeitar os 3 cadernos?

(PROVINHA)

Para enfeitar o pátio da escola, os colegas de Lucas fizeram 4 cordões com 120 bandeirinhas em cada um. Quantas bandeirinhas foram feitas?

(BEM-ME-QUER 3ํANO)

A professora de Dora organizou todos os alunos da turma em 6 grupos com 4 alunos em cada um.

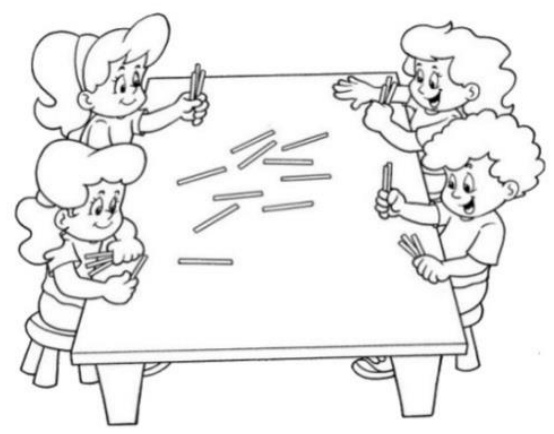

Quantos alunos havia na turma de Dora?

(BEM-ME-QUER $2^{\circ}$ ANO)

Uma banca de jornais lançou uma promoção: na compra de 4 gibis, o cliente ganha 1 pacote de figurinhas. Para ganhar 3 pacotes de figurinhas, quantos gibis é preciso comprar?

(BEM-ME-QUER $3^{\circ}$ ANO) 


\section{Configuração retangular}

Num auditório, as cadeiras estão dispostas em 7 fileiras e 8 colunas. Quantas cadeiras há no auditório?

$(\mathrm{PCN})$

Antônio plantou 2 fileiras com 5 árvores em cada uma. Quantas árvores Antônio plantou no total?

(PROVINHA)

O irmãozinho de Caio cortou o tabuleiro do jogo de damas.

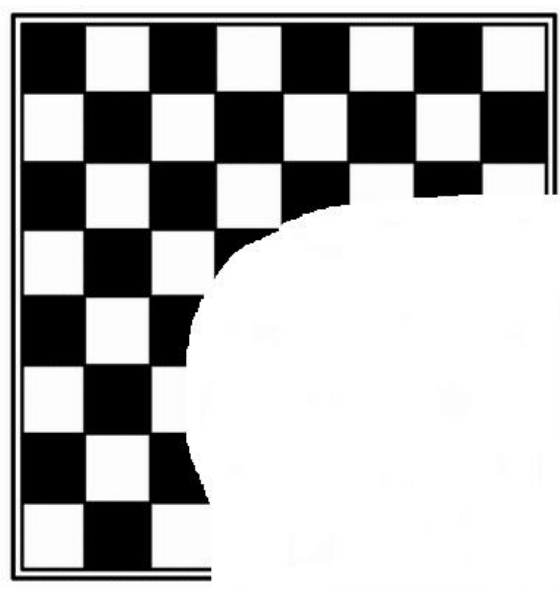

Quantos quadradinhos havia no tabuleiro antes desse acidente?

(BEM-ME-QUER 3ํANO)

Um prédio tem 5 andares. Em cada andar há 4 apartamentos. Quantos apartamentos há no prédio? 
Gabriela e seu amigo estavam brincando com o jogo da memória e organizaram as cartas em linhas e colunas. Veja:
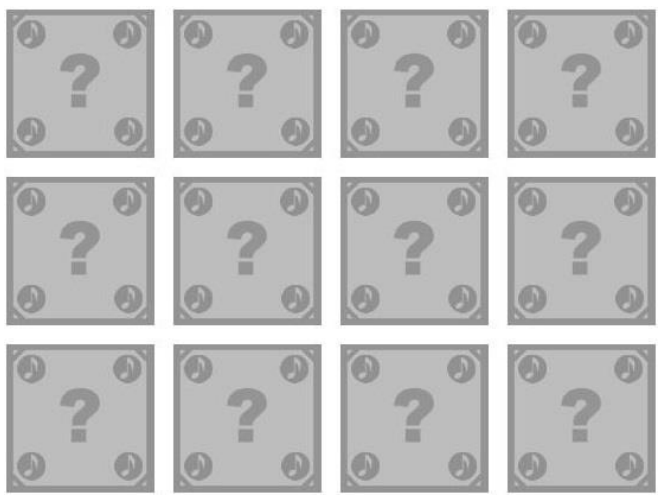

Quantas cartas o jogo tem ao todo?

(BEM-ME-QUER 3№NO)

\section{Combinatória}

Tendo 2 saias e 3 blusas, de quantas maneiras diferentes posso me vestir?

$(\mathrm{PCN})$

$\mathrm{Na}$ carrocinha de pipoca, a garotada podia escolher pipoca doce, salgada ou mista, nos tamanhos pequeno, médio ou grande. De quantas maneiras eles podiam combinar os sabores e tamanhos?

(BEM-ME-QUER 3ํANO)

Quantos conjuntos diferentes de uma calça e uma camisa podem ser formador com 3 calças distintas e 4 camisas diferentes entre si?

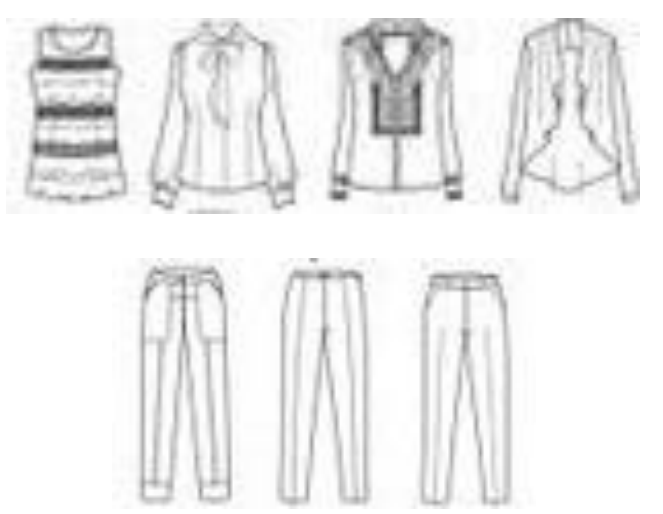


Em uma sorveteria, o sorvete pode ser servido em casquinho ou copinho. São 4 sabores diferentes: menta, baunilha, chocolate e morango. Maria quer uma bola de sorvete. Quantas combinações diferentes ela tem para escolher?

(GITIRANA)

Em uma barraquinha que servia sanduíche, era possível pedir com recheio de salsicha ou linguiça, com molho ou sem molho. De quantas maneiras era possível pedir um sanduíche?

(BEM-ME-QUER $3^{\circ}$ ANO) 